RICARDO ANTONIO FERREIRA SANTANA

\title{
ANÁLISE DA PRESERVAÇÃO DO CURURU NAS RÁDIOS DE PIRACICABA-SP
}

Dissertação apresentada à Área de Concentração de Ciências da Comunicação da Escola de Comunicação e Artes da Universidade de São Paulo, como exigência parcial para a obtenção do título de mestre em Ciências da Comunicação, sob a orientação do Prof. Dr. Luiz Roberto Alves.

Universidade de São Paulo

São Paulo

2007 
RICARDO ANTONIO FERREIRA SANTANA

\section{ANÁLISE DA PRESERVAÇÃO DO CURURU NAS RÁDIOS DE PIRACICABA-SP}

Dissertação apresentada à Área de Concentração de Ciências da Comunicação da Escola de Comunicação e Artes da Universidade de São Paulo, como exigência parcial para a obtenção do título de mestre em Ciências da Comunicação, sob a orientação do Prof. Dr. Luiz Roberto Alves.

Universidade de São Paulo

São Paulo 
BANCA EXAMINADORA

Data:

' 


\section{AGRADECIMENTOS}

Ao Prof. Dr Luiz Roberto Alves, meu orientador, que contribuiu para meu crescimento como pesquisador;

À Faculdades Claretianas e meus colegas que me apoiaram, em especial aos amigos Rogério, Sâmia e Mauricio Bueloni;

À Bia Pascarelli, pelas valiosas contribuições;

Ao amigo Du Cury, pela revisão final;

Aos cururueiros, preservadores da cultura em estudo, pela contribuição de seus depoimentos que permitiram este aprendizado;

Aos proprietários e representantes das rádios de Piracicaba;

À Cálica Lopes, minha maior incentivadora, pelo carinho e colaboração;

A todos que de alguma forma contribuíram para a realização desta pesquisa;

Aos meus pais, a quem dedico este trabalho, pelo carinho e incentivo de sempre. 


\section{RESUMO}

Esta dissertação trata exatamente da possibilidade de investigar, com os efeitos das mudanças tecnológicas, econômicas e culturais pelas quais o mundo vem passando, a possibilidade dos meios de comunicação, em particular a comunicação radiofônica, de viabilizar o uso de sua potencialidade para difusão dos movimentos de cultura popular, em especial o cururu, repente do interior paulista. Buscou-se também entender a influência dessas mudanças no cururu, pois nota-se que este vem modificando suas características para resistir diante desse desenvolvimento nos meios de comunicação de massa. O estudo em questão aborda a importância da preservação da cultura local nas emissoras de rádio da cidade de Piracicaba, localizada no interior do estado de São Paulo. Em suas considerações finais, o estudo apresenta dados indicadores do quanto as rádios e os cururueiros da cidade respondem a essas questões, e sugere ações para que as emissoras exerçam seu papel junto aos grupos sociais organizadores, de contribuir com a difusão desta manifestação cultural.

Palavras-chave: Cultura popular, cultura de massa, processos comunicacionais, cururu, manifestações culturais. 


\begin{abstract}
This dissertation signs the possibility of investigating - with the effect of the technological, economic and cultural changes in the world and in mass communication, in particular on radio broadcasting - how to use radio's potentiality for the diffusion of popular culture movements, in special the tradition of cururu, a kind of country music free style battle from São Paulo's countryside. It also search to understand how these changes influenced cururu itself, as it has been modifying its characteristics to resist in face of the development of the mass medias. This study shows the importance of the preservation of the local culture by the radio stations of Piracicaba city, located in the interior of São Paulo State. In its final consideration, the study presents data indicating where the local radio stations and cururueiros (a person who performs the cururu) stands about this matter. It also points out ways mutual cooperation and how the radios stations can play a leading role in the spread of this popular culture.
\end{abstract}

Key words: Popular culture, mass culture, communication processes, cururu, cultural manifestations 


\section{SUMÁRIO}

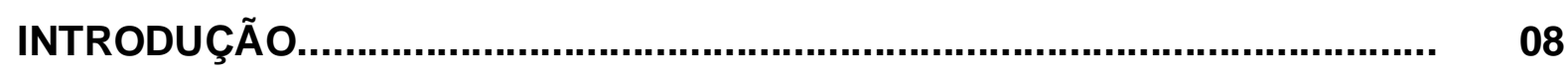

CAPÍTULO I - DO ERUDITO AO POPULAR............................................... 14

1.1 Idéias sobre a origem e conceitos de cultura ................................. 15

1.2 Teorias modernas sobre cultura ................................................. 20

1.3 Como opera a cultura .................................................................. 22

1.3.1 A visão de mundo condicionada pela cultura ....................... 23

1.3.2 Hierarquias sociais e culturais ............................................ 24

1.3.3 Conceito de cultura renovado ............................................ 27

1.4 Dinamismo cultural ............................................................... 27

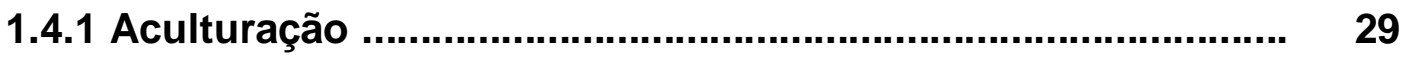

1.4.2 Cultura e Identidade ....................................................... $\quad 30$

1.4.3 Concepção relacional e situacional ...................................... 32

1.5 Capitalismo e cultura de massa .................................................... 33

1.5.1 A residência da cultura de massa ........................................ 34

1.5.2 Cultura de massa ............................................................ 39

1.5.3 Crítica à teoria da cultura de massa ..................................... 41

1.5.4 A preocupação social com os mass media .......................... $\quad 42$

1.5.5 Efeitos sobre a cultura e o gosto popular .............................. 44

1.6 As culturas populares ............................................................... 46

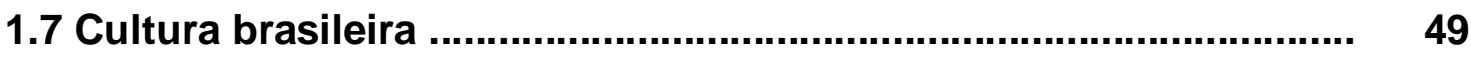

CAPÍTULO II - UMA VIOLA, UMA RODA, UMA TRADIÇÃO ....................... 55

2.1 Origem do cururu .................................................................... 56

2.1.1 Definições de cururu ......................................................... 58

2.1.2 Repente e desafio .............................................................. 62

2.1.3 Carreiras ou rimas ............................................................ 64

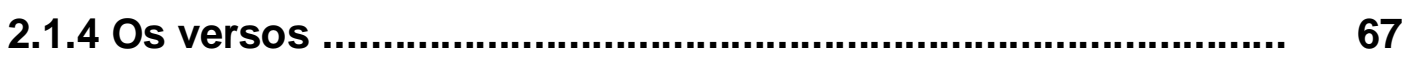



2.1.6 O cururu como dança .......................................................... 77

2.1.7 "Rural" e "urbano" ................................................................ 78 
2.1.8 Cururueiros ....................................................................... 81

2.1.9 O cururu na mídia ............................................................. 84

2.1.10 Onde existe o cururu ........................................................ 87

CAPÍTULO III - VILA NOVA DA CONSTITUIÇÃO ......................................... 89

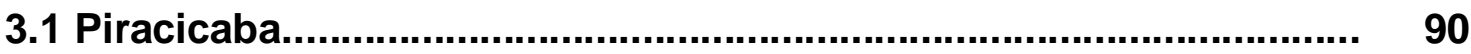

3.2 Estrategicamente privilegiada...................................................... 97

3.30 poder da cana e do café.......................................................... 100

3.4 Crescimento urbano e surgimento das indústrias.......................... 104

3.5 Tradição e fé contra as doenças................................................... 107

3.6 Rua da Praia e do Porto............................................................ 110

CAPÍTULO IV - AS RÁDIOS DE PIRACICABA E SUAS RELAÇÕES COM O

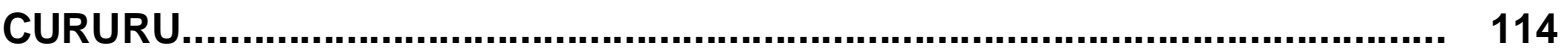

4.1 As rádios de Piracicaba.............................................................. 115

4.1.1 Difusora AM/FM ............................................................... 116

4.1.2 FM Municipal/Educativa FM .............................................. 119

4.1.3 Educadora AM ................................................................ 122

4.1.4 Educadora FM/Jovem Pan .............................................. 125

4.1.5 Alvorada AM (Globo) ..................................................... 126

4.1.6 Rádio 97 FM Universal ...................................................... 129

4.20 cururu nas rádios de Piracicaba .............................................. 130

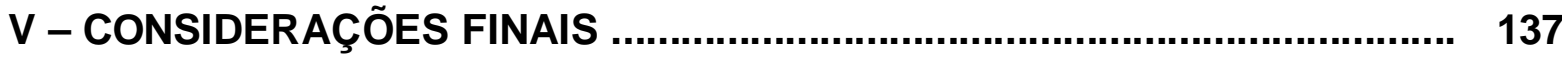

VI - REFERÊNCIAS BIBLIOGRÁFICAS ................................................ 143

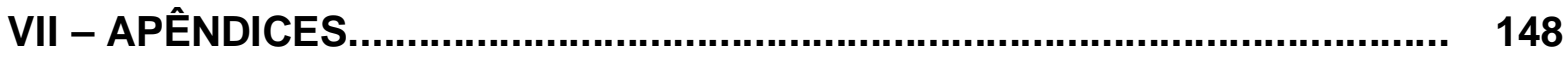

VIII - ANEXOS 
INTRODUÇÃO 


\section{Introdução}

Os meios de comunicação de massa, principalmente o rádio e a televisão, hoje são considerados grandes influenciadores nas mudanças dos hábitos, costumes e valores da sociedade, tendo um importante papel na construção da cultura de um povo, devido ao fácil acesso a eles.

O rádio, por ser um instrumento de fácil portabilidade, torna-se ainda mais importante nessa questão, dado o fato de que o seu acesso possa ser feito enquanto as pessoas desenvolvem outras atividades, como dirigir, comer e trabalhar, recebendo informações o tempo todo, sejam elas sobre a cidade, o país e até mesmo sobre o mundo.

Responsável também pelo entretenimento e por se tornar um grande influenciador na cultura local de uma cidade, o rádio atribui pouca importância para as conseqüências de sua programação no que se refere à preservação de uma manifestação cultural local, dando mais importância aos produtos que são mais comercializáveis.

A programação radiofônica possibilita ao homem o acesso à cultura de outros povos, podendo conhecer suas músicas, línguas e valores. Mas, por outro lado, o homem precisa se identificar com a comunidade onde vive participando de ações que o colocam como agente dessa comunidade.

No decorrer da elaboração desta dissertação, pode-se aprender que a origem da cultura é uma das primeiras preocupações dos estudiosos em saber como o homem adquiriu esse processo, uma dificuldade que resulta não da falta de definições, mas do excesso de definições existentes. Todos os campos da humanidade, da filosofia à antropologia, e esta especialmente, possuem definições 
específicas de cultura, adaptadas à delimitação das fronteiras do conhecimento que cada um desses campos recobre.

Outro assunto discorrido é a mudança cultural, na qual existem dois tipos: uma que é interna, resultante da dinâmica do próprio sistema cultural; e uma segunda, que é o resultado do contato de um sistema cultural com outro. Entender essa dinâmica é importante para atenuar o choque entre as gerações e evitar comportamentos preconceituosos.

O que se vê é uma cultura consumida através dos veículos de comunicação de massa - televisão, jornais, rádio, cinema, propaganda - e o que tem sido oferecido é um "produto" de baixa qualidade porque, para ser consumido pela massa, é preciso ser nivelado por baixo.

Como registrado nas ações exploratórias deste trabalho, percebe-se que o cururu está perdendo sua originalidade, criando assim um "produto" de baixa qualidade para conseguir espaço nos meios de comunicação de massa, principalmente no rádio, que cada vez mais o tem excluído de suas programações.

Este trabalho trata das potencialidades do processo comunicacional radiofônico, com ênfase na radiodifusão em Piracicaba, cidade do interior do estado de São Paulo, no que diz respeito à sua participação como agente atuante na preservação de uma das suas principais tradições culturais, o cururu. Visa a contribuir para o desenvolvimento de uma teoria que aborde a influência dos meios de comunicação de massa sobre as culturas locais.

Piracicaba fica a $176 \mathrm{~km}$ da cidade de São Paulo, localizada em uma das regiões mais desenvolvidas e industrializadas do estado paulista, com aproximadamente 365.000 habitantes e uma economia historicamente vinculada à produção agrícola e industrial, com destaque ao setor sucroalcooleiro. 
Os primeiros habitantes foram os índios Paiaguás, também conhecidos como gentios. Logo no século XVIII, ao redor do salto do rio Piracicaba, surgiu a primeira povoação que se dedicava a caça, pesca e construção de barcos. Assim, o salto do rio teve grande influência na expansão dos colonizadores portugueses, possuidores de cartas sesmaria, atraídos pela terra de boa qualidade, pesca abundante, madeira e pela caça.

Em função da localização, os principais rios de São Paulo - o Tietê e o Piracicaba - acabaram se tornando os principais eixos de trânsito do colonizador europeu no estado. No final do século XIX, com o fim do período escravista, finalmente vieram os imigrantes italianos, seguidos a distância pelos sírio-libaneses, espanhóis, portugueses, alemães, tiroleses, suíços, japoneses e judeus, como mãode-obra adicional.

O rio de Piracicaba tem um grande significado para o povo da cidade; é sinônimo de história, desenvolvimento, cultura e paixão, com grandes edificações e conjuntos arquitetônicos em sua orla, que são considerados símbolos de crescimento, tradição popular e multipluralidade cultural - um exemplo é o Engenho Central situado logo abaixo do salto.

A Rua do Porto, antiga "Rua da Praia", é considerada o berço da cultura "caipiracicabana" e o local da cidade com o qual o povo mais se identifica; nela estão situados o Largo dos Pescadores, onde acontecem a Festa do Divino, a Seresta e Rodas de Cururu, e o conjunto de restaurantes onde são servidas as comidas típicas da cidade.

Piracicaba é muito conhecida por possuir uma pluralidade de manifestações culturais e por conservar muitos costumes seculares que desapareceram na maioria das cidades. Dentre essas manifestações, relacionam-se a Festa de São João de 
Tupi, a Festa do Milho, a Festa do Divino, a Catira, o Cateretê e, principalmente, o Cururu.

Por essas razões, a cidade foi escolhida para objeto deste trabalho, por sua rica e diversificada cultura popular e por ser considerada a "Capital do Cururu".

As emissoras de rádios pesquisadas foram as sete existentes na cidade, das quais três AMs e quatro FMs. As emissoras de AM são Difusora, Educadora e Globo (antiga Alvorada). Já as emissoras que retransmitem em FM são Educativa FM, Jovem Pan, 97 FM Universal (associada à Rádio Alvorada) e Difusora.

A concepção metodológica utilizada neste trabalho permitiu articular conceitos a partir dos dados obtidos por diferentes técnicas. A combinação entre a revisão teórica, a pesquisa histórica e as ações exploratórias resultaram em importantes indicadores que dirigiram a pesquisa empírica, cujas pesquisas históricas resultaram na obtenção de dados reveladores. Estes puderam ser enriquecidos com os dados oriundos das entrevistas, de roteiro não estruturado.

De volta ao referencial teórico, a dialética estabelecida entre os dados permitiu uma reflexão analítica sobre o objeto de estudo e, a partir dela, foram elaboradas considerações e novos questionamentos, num processo de interpretação criativa.

O primeiro capítulo, DO ERUDITO AO POPULAR, buscará discutir a origem e os conceitos de cultura e algumas idéias sobre a teoria moderna de cultura e de como ela condiciona a visão de mundo. Tratará da mudança cultural, dos processos de aculturação e a questão identitária e sua relação com as manifestações culturais. Procurará discutir como o capitalismo influiu na cultura de massa, o seu conceito e o consumo nos meios de comunicação de massa. E, por fim, o conceito de cultura popular e o caráter plural da cultura brasileira. 
O segundo capítulo, UMA VIOLA, UMA RODA, UMA TRADIÇÃO, é dedicado ao cururu e buscará conhecer a sua origem, como são desenvolvidas suas rimas e carreiras, o uso de sua temática com o impacto da modernização, as mudanças ocorridas através do tempo e sua trajetória na mídia através dos grandes cantadores, ocupando-se apenas do cururu da região do Médio Tietê, no interior do estado de São Paulo.

O terceiro capítulo, VILA NOVA DA CONSTITUIÇÃO, apresentará as origens da cidade de Piracicaba, sua história, sua localização e seu desenvolvimento econômico e industrial. Apresentará também Piracicaba como reduto de várias manifestações culturais e de locais de grande identificação cultural, para compreender os valores amalgamados na identidade ou no imaginário cultural da comunidade.

O quarto capítulo, AS RÁDIOS DE PIRACICABA E SUAS RELAÇÕES COM O CURURU, contará a história das rádios da cidade e como atualmente são estruturadas as suas programações e possíveis relações estabelecidas com as manifestações culturais locais e com o cururu. Apresentará também dados resultantes das entrevistas sobre a influência do desenvolvimento no processo radiofônico em Piracicaba e no cururu.

Finalmente, o trabalho mostrará considerações que permitirão indicar algumas ações com o intuito de contribuir para a construção de uma nova relação da emissora com os agentes organizadores da principal manifestação cultural da cidade, o cururu, bem como levantará questionamentos passíveis de constituir novos estudos. 
CAPÍTULO I

DO ERUDITO AO POPULAR 


\section{Do erudito ao popular}

Tomando como base a concepção de tempo, este capítulo tem como principal foco a relação entre a cultura erudita, cultura popular e cultura de massa, sendo que o surgimento desta última significou modificações nos demais sistemas culturais, podendo acarretar mudanças significativas ou não na comunicação de uma comunidade ou de um determinado grupo.

Mesmo sendo influenciadas pelos meios de comunicação de massa, a cultura erudita e principalmente a cultura popular criam uma resistência, intencional ou não, conservando, assim, uma história interna e ritmo próprio. Nesse sentido, vê-se a necessidade de discorrer sobre os diferentes conceitos de cultura sob a perspectiva de diferentes autores.

\subsection{Idéias sobre a origem e conceitos de cultura}

Estabelecer o conceito de cultura é uma tarefa extremamente difícil para os pesquisadores. Tal dificuldade resulta não da falta de definições, mas do excesso destas. Cada campo da humanidade, ou seja, da filosofia às ciências sociais, da fisiologia à antropologia, e esta especialmente, possui definições específicas de cultura, adaptadas à delimitação das fronteiras do conhecimento que cada um desses campos recobre.

Para Laraia (2001), a origem da cultura é uma das primeiras preocupações dos estudiosos, que buscam saber como o homem adquiriu este processo extrasomático que o diferencia de todos os animais, ocupando, dessa forma, um lugar privilegiado na vida terrestre.

De acordo com o autor, 
no final do século XVIII e no princípio do seguinte, o termo germânico Kultur era utilizado para simbolizar todos os aspectos espirituais de uma comunidade, enquanto a palavra francesa Civilization referia-se principalmente às realizações materiais de um povo. ${ }^{1}$

Edward Burnett Tylor (1832-1917), antropólogo britânico, foi o primeiro a dar uma definição etnológica para o termo cultura. Em sua concepção,

Cultura e civilização, tomadas em seu sentido etnológico mais vasto, são um conjunto complexo que inclui o conhecimento, as crenças, a arte, a moral, o direito, os costumes e as outras capacidades ou hábitos adquiridos pelo homem enquanto membro da sociedade. ${ }^{2}$

Este sentido corresponde às formas de organização de um povo, seus costumes e tradições transmitidas de geração para geração, que, a partir de uma vivência e tradição comum, apresentam-se como identidade desse povo.

Cuche (2002), analisando as palavras de Tylor, entende que "a cultura é adquirida e não depende da hereditariedade biológica. No entanto, se a cultura é adquirida, sua origem e seu caráter são, em grande parte, inconscientes."3

Tomando como exemplo o direito, as leis, as normas, o homem como membro de uma sociedade deve seguir regras que são criadas para manter o bom relacionamento entre as pessoas e limitar suas ações, de modo que cada indivíduo respeite a integridade física e moral do outro. Dessa forma, uma pessoa que vive em um determinado país está submetida às normas deste; ao se mudar para outro país que tem um ordenamento jurídico diferente, deverá se adequar as normas daquele,

\footnotetext{
${ }_{1}^{1}$ LARAIA, Roque de Barros. Cultura: um conceito antropológico. p. 25.

2 TYLOR, Edward B. La Civilization primitive. Paris: Reindwald, 1876-1878, 2v, p. 1

${ }^{3}$ CUCHE, Denys. A noção de cultura nas ciências sociais p. 35.
} 
aprender a conviver com novas regras, adquirindo uma nova cultura para se manter dentro daquela sociedade.

O dicionário filosófico abreviado, de M. Rosental e P. Iudin, define cultura como:

\begin{abstract}
Conjunto dos valores materiais e espirituais criados pela humanidade, no curso de sua história. A cultura é um fenômeno social que representa o nível alcançado pela sociedade em determinada etapa histórica: progresso, técnica, experiência de produção e de trabalho, instrução, educação, ciência, literatura, arte e instituições que Ihes corresponde. Em um sentido mais restrito, compreende-se, sob o termo de cultura, o conjunto de formas da vida espiritual da sociedade, que nascem e se desenvolvem à base do modo de produção dos bens materiais historicamente determinado. Assim, entende-se por cultura o nível de desenvolvimento alcançado pela sociedade na instrução, na ciência, na literatura, na arte, na filosofia, na moral, etc., e as instituições correspondentes. Entre os índices mais importantes do nível cultural, em determinada etapa histórica, é preciso notar o grau de utilização dos aperfeiçoamentos técnicos e dos desenvolvimentos científicos na produção social, o nível cultural e técnico dos produtores dos bens materiais, assim como o grau de difusão da instrução, da literatura, e das artes entre a população. ${ }^{4}$
\end{abstract}

Para Lévi-Strauss, a cultura surge no mesmo momento em que surge a primeira norma, ou seja, a primeira regra. Desse modo, definiu que

Toda cultura pode ser considerada como um conjunto de sistemas simbólicos. No primeiro plano destes sistemas colocam-se a linguagem, as regras matrimoniais, as relações econômicas, a arte, a ciência, a religião. Todos estes sistemas buscam exprimir certos aspectos da realidade social, e mais ainda, as relações que estes dois tipos de realidade estabelecem entre si e que os próprios sistemas simbólicos estabelecem uns com os outros ${ }^{5}$.

Muylaert diz que a cultura está relacionada a atividades de campos diversos, como a música, a arte, o teatro a dança, a literatura, dentre outras, que revelem uma forma de se organizar socialmente expressando as características de um povo, uma

\footnotetext{
${ }^{4}$ ROSENTAL de M. e IUDIN, P. apud SODRÉ, Nelson Werneck. Síntese de história da cultura brasileira. p. 03.

${ }^{5}$ LEVY-STRAUSS apud CUCHE, Denys. Op. Cit. p. 95.
} 
manifestação original que prevê um intercâmbio permanente de realizações e experiências.

Kroeber contribui para a ampliação do conceito de cultura relacionando os seguintes pontos:

1. A cultura, mais do que a herança genética, determina o comportamento do homem e justifica as suas realizações;

2. O homem age de acordo com os seus padrões culturais. Os seus instintos foram parcialmente anulados pelo longo processo evolutivo por que passou;

3. A cultura é o meio de adaptação aos diferentes ambientes ecológicos. Em vez de modificar para isto o seu aparato biológico, o homem modifica o seu equipamento super orgânico;

4. Em decorrência da afirmação anterior, o homem foi capaz de romper as barreiras das diferenças ambientais e transformar toda a terra em seu habitat;

5. Adquirindo cultura, o homem passou a depender muito mais do aprendizado do que a agir através de atitudes geneticamente determinadas;

6. Como já era do conhecimento da humanidade, desde o Iluminismo, é este processo de aprendizagem (socialização ou endoculturação, não importa o termo) que determina o seu comportamento e a sua capacidade artística ou profissional;

7. A cultura é um processo acumulativo, resultante de toda a experiência histórica das gerações anteriores. Este processo limita ou estimula a ação criativa do indivíduo;

8. Os gênios são indivíduos altamente inteligentes que têm a oportunidade de utilizar o conhecimento existente ao seu dispor, construído pelos participantes vivos e mortos de seu sistema cultural, e criar um novo objeto ou uma nova técnica. Nesta classificação podem ser incluídos os indivíduos que fizeram as primeiras invenções, tais como o primeiro homem que produziu o fogo através do atrito da madeira seca; ou o primeiro homem que fabricou a primeira máquina capaz de ampliar a força muscular, o $\operatorname{arco}$ e a flecha etc. são eles gênios da mesma grandeza de Santos Dumont e Einstein. Sem as suas primeiras invenções ou descobertas, hoje consideradas modestas, não teriam ocorrido as demais. $E$ pior do que isto, talvez nem mesmo a espécie humana teria chegado ao que é hoje ${ }^{6}$.

Titiev, em seu livro Introdução à antropologia cultural, afirma que o termo cultura pode referir-se aos aspectos não biológicos da humanidade no seu conjunto ou pode respeitar apenas à forma de vida de um determinado grupo de homens e mulheres. Nos dois casos, os antropólogos usam o termo para descrever a série

\footnotetext{
${ }^{6}$ LARAIA, Roque de Barros. Op. Cit. p. 48 e 49.
} 
completa dos instrumentos não geneticamente adquiridos pelo homem, assim como todas as características do comportamento adquiridas após o nascimento. Afirma também que a cultura em todos os aspectos difere da biologia humana, ou seja, a cultura não se compõe somente de ingredientes biofísico-químicos; não é transmitida nas relações sexuais; não se transmite num determinado momento; não é recebida apenas de duas pessoas que vão ser os pais de um indivíduo; e em teoria ela não tem de ser retida para toda vida, podendo, pelo contrário, ser modificada ou abandonada de acordo com o desejo de um indivíduo. E devido a razões práticas, os seres humanos raras vezes se prestam a fazer voluntariamente modificações radicais nas culturas que aprenderam dos seus mentores, concluindo que "é mais fácil modificar a língua ou a religião de uma pessoa do que a forma da sua cabeça ou a cor dos seus olhos". 7

Titiev, ao mencionar sobre as sociedades humanas, entende que elas

são os únicos grupos de todo o reino animal que delinearam formas de cultura que, por sua vez, exercem poderosas influências modificadoras nos mecanismos hereditários dos seus membros individuais. Algumas vezes os elementos culturais e biológicos coincidem ou reforçam-se uns aos outros ao procurarem os mesmos objetivos; outras vezes não têm nenhum efeito uns sobre os outros; e por vezes chegam a chocar-se ou a opor-se entre si. ${ }^{8}$

Diante dos mais diversos conceitos dispensados a cultura, percebe-se que esta não aparece mais como uma simples reunião de traços dispersos, mas como um conjunto organizado de elementos interdependentes. Seu conteúdo é tão importante quanto sua organização.

\footnotetext{
${ }^{7}$ TITIEV, Mischa. Introdução à antropologia cultural. p. 13.

${ }^{8}$ Ibid. p.14.
} 
Para Cuche, referir-se à cultura é reportar-se aos modos de vida e de pensamento de uma sociedade. Sendo assim, pode ser compreendida num sentido muito amplo e, assim, gerar ambigüidades quando se trata de sua conceituação. Entretanto, apesar dessa dificuldade, tal concepção é bastante aceita atualmente. Esta aceitação nem sempre existiu. Desde seu aparecimento no século XVIII, a idéia moderna de cultura suscitou e suscita constantemente debates acirrados.

\subsection{Teorias modernas sobre cultura}

Como já referido no subitem 1.1 desse capítulo, a noção de cultura é muito ampla, podendo gerar ambigüidades em seu significado, mas ao mesmo tempo esta noção obtém um sucesso crescente. A sua definição guarda a tendência de ultrapassar outros termos que hoje acabaram por se tornar obsoletos, como "mentalidade", "espírito", "tradição" e até "ideologia".

Cuche assevera que

o uso sem controle da noção de cultura provoca uma confusão conceitual. No entanto, o exame de alguns casos recentes e significativos da aplicação do conceito de cultura a um campo particular pode mostrar a defasagem que se produz cada vez mais entre o uso social, isto é, ideológico e o uso científico do conceito. ${ }^{9}$

De acordo com Laraia, a reconstrução do conceito de cultura é uma das tarefas da antropologia moderna. O antropólogo Roger Keesing, em seu artigo "Theories of Culture", classifica as tentativas de se obter uma precisão conceitual. O

${ }^{9}$ CUCHE, Denys. Op. Cit.p. 205. 
autor se refere às teorias que consideram a cultura um sistema adaptativo e às teorias idealistas de cultura..

A primeira foi difundida por neo-evolucionistas, como Leslie White; esta posição foi reformulada criativamente por Sahlins, Harris, Carneiro, Rappaport, Vayda e outros que, apesar das fortes divergências que apresentam entre si, concordam em que

1. Culturas são sistemas (de padrões de comportamento socialmente transmitidos) que servem para adaptar as comunidades humanas aos seus embasamentos biológicos. Esse modo de vida das comunidades inclui tecnologias e modos de organização econômica, padrões de estabelecimento, de agrupamento social e organização política, crenças e práticas religiosas, e assim por diante;

2. Mudança cultural é primariamente um processo de adaptação equivalente à seleção natural. (o homem é um animal e, como todos os animais, deve manter uma relação adaptativa com o meio circundante para sobreviver. Embora ele consiga esta adaptação através da cultura, o processo é dirigido pelas mesmas regras de seleção natural que governam a adaptação biológica. B. Meggers, 1977);

3. A tecnologia, a economia de subsistência e os elementos da organização social diretamente ligada à produção constituem o domínio mais adaptativo da cultura. É neste domínio que usualmente começam as mudanças adaptativas que depois se ramificam. Existem, entretanto, divergências sobre como opera este processo. Estas divergências podem ser notadas nas posições do materialismo cultural, desenvolvido por Marvin Harris, na dialética social dos marxistas, no evolucionismo cultural de Elman Service e entre os ecologistas culturais, como Steward;

4. Os componentes ideológicos dos sistemas culturais podem ter conseqüências adaptativas no controle da população, da subsistência, da manutenção do ecossistema etc. ${ }^{10}$

De outro lado, as teorias idealistas de cultura subdividem-se em três

diferentes abordagens, quais sejam: a) a cultura como sistema cognitivo; b) como sistema estrutural; c) como sistema simbólico.

A primeira delas, considerada proveniente de sistemas cognitivos, é "produto dos chamados 'novos etnógrafos'. Esta abordagem antropológica tem se distinguido

\footnotetext{
${ }^{10}$ LARAIA, Roque de Barros. Op. Cit.pp. 59 e 60.
} 
pelo estudo dos sistemas de classificação de folk, isto é, a análise dos modelos construídos pelos membros da comunidade a respeito de seu próprio universo".

A segunda abordagem, sistema estrutural, ou seja, a perspectiva desenvolvida por Claude Lévi-Strauss, define cultura como algo que a mente humana acumula num sistema simbólico. O trabalho deste autor tem sido se pautar em como acontece a estruturação dos domínios culturais, em como a mente humana elabora a questão do mito, arte, parentesco e linguagem.

A última das três abordagens, a que considera cultura sistemas simbólicos, foi desenvolvida nos Estados Unidos principalmente por dois antropólogos: Clifford Geertz e David Schneider.

O primeiro deles, Geertz, busca uma definição de homem baseada na definição de cultura. Em outras palavras, a criança está apta ao nascer a ser socializada em qualquer cultura existente. Esta amplitude de possibilidades, entretanto, será limitada pelo contexto real e específico onde de fato ela crescer.

Já o segundo, David Schneider, defende uma abordagem distinta, mas com alguns pontos semelhantes a Geertz. De acordo com o seu ponto de vista, cultura é um sistema de símbolos e significados, com categorias ou unidades e regras sobre relações e modos de comportamento.

Concluindo, para se ter uma compreensão exata do conceito de cultura devese compreender a própria natureza humana, tema perene da incansável reflexão humana. Murdock (1932) afirma que "os antropólogos sabem de fato o que é cultura, mas divergem na maneira de exteriorizar este conhecimento"11

\subsection{Como opera a cultura}

\footnotetext{
${ }^{11}$ MURDOCK apud LARAIA, Roque de Barros. Op. Cit.p. 63.
} 


\subsubsection{A visão de mundo condicionada pela cultura}

O homem tende a reagir de forma depreciativa em relação ao comportamento adverso daqueles que agem fora dos padrões aceitos pela comunidade em que ele se encontra.

A cultura condiciona a visão de mundo do homem, para Laraia:

A nossa herança cultural, desenvolvida através de inúmeras gerações, sempre nos condicionou a reagir depreciativamente em relação ao comportamento daqueles que agem fora dos padrões aceitos pela maioria da comunidade. Por isto, discriminamos 0 comportamento desviante. ${ }^{12}$

Ruth Benedict, citada por Laraia, escreveu em seu livro O crisântemo e a espada que "o homem pode ver o mundo através de uma lente. Esta lente é a cultura. Homens de culturas diferentes usam lentes diversas e, portanto, têm visões desencontradas das coisas".

Os homens estão divididos em grupos, cada qual com sua cultura, costumes, regras, tradições, etc. Cada grupo tem um ponto de vista das coisas, o que pode causar, muitas vezes, discórdia.

O homem tem despendido grande parte da sua história na Terra, separado em pequenos grupos, cada um com a sua própria linguagem, sua própria visão de mundo, seus costumes e expectativas.

O modo de ver o mundo, as apreciações de ordem moral e valorativa, os diferentes comportamentos sociais e mesmo as posturas corporais são assim produtos de uma herança cultural, ou seja, o resultado da operação de uma determinada cultura ${ }^{13}$.

\footnotetext{
${ }^{12}$ LARAIA, Roque de Barros. Op. Cit.p. 67.

${ }^{13}$ Ibid. p. 68.
} 
Existem características muito peculiares em indivíduos da mesma cultura. Qualquer pessoa pode facilmente identificar que um indivíduo pertence a uma determinada cultura não apenas pela evidência da diferença no idioma, mas simplesmente ao perceber o seu modo de agir, caminhar, vestir-se, comer. Isto se configura numa observação empírica. Até mesmo, situações consideradas fisiológicas podem configurar diferentes culturas.

\subsubsection{Hierarquias sociais e culturais}

A humanidade está dividida em diferentes grupos sociais, que seguem uma hierarquia social e cultural, sendo que a primeira determina a hierarquia da segunda.

O encontro das culturas não se produz somente entre sociedades globais, mas também entre grupos sociais pertencentes a uma mesma sociedade complexa. Como estes grupos são hierarquizados entre si, percebe-se que as hierarquias sociais determinam as hierarquias culturais, o que não significa que a cultura do grupo dominante determine o caráter das culturas dos grupos socialmente dominados. As culturas das classes populares não são desprovidas de autonomia nem de capacidade de resistência. ${ }^{14}$

Nesse sentido, o mesmo autor conclui que,

na medida em que a cultura real só existe se produzida por indivíduos ou grupos que ocupam posições desiguais no campo social, econômico e político, as culturas dos diferentes grupos se encontram em maior ou menor posição de força (ou de fraqueza) em relação às outras. Mas mesmo o mais fraco não se encontra jamais totalmente desarmado no jogo cultural. ${ }^{15}$

\footnotetext{
${ }^{14}$ CUCHE, Denys. Op. Cit.p. 14.
}

${ }^{15}$ Ibid. p. 144. 
Marx e Weber não se enganaram ao afirmar que em um dado espaço social, existe sempre uma hierarquia cultural e que a cultura da classe dominante é sempre a que prevalece.

Ao dizer isto, eles não pretendem evidentemente afirmar que a cultura da classe dominante seria dotada de uma espécie de superioridade intrínseca ou mesmo de uma força de difusão que viria de sua própria "essência" e que permitiria que ela dominasse "naturalmente" as outras culturas. Para Marx assim como para Weber, a força relativa de diferentes culturas em competição depende diretamente da força social relativa dos grupos que as sustentam. Falar de cultura "dominante" ou de cultura "dominada" é então recorrer a metáforas; na realidade o que existe são grupos sociais que estão em relação de dominação ou de subordinação uns com os outros. ${ }^{16}$

Cuche, ao analisar a afirmação de Marx e Weber, entende que uma cultura dominante não pode se impor totalmente a uma cultura dominada como um grupo pode fazê-lo em relação a um outro grupo mais fraco.

A dominação cultural nunca é total e definitivamente garantida e, por esta razão, ela deve sempre ser acompanhada de um trabalho para inculcar esta dominação cujos efeitos não são jamais unívocos; eles são às vezes "efeitos perversos", contrários às expectativas dos dominantes, pois sofrer a dominação não significa necessariamente

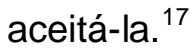

No livro Os parceiros do Rio Bonito, de Antônio Cândido, a desagregação da cultura rústica do caipira aparece em contato com as cidades, ou seja, os centros urbanos e industrializados.

\footnotetext{
${ }^{16}$ CUCHE, Denys. Op. Cit.p. 145.
}

${ }^{17}$ Ibid. p. 146. 
"A cultura das cidades vai absorvendo as variedades culturais rústicas e desempenha cada vez mais o papel de cultura dominante, impondo as suas técnicas, padrões e valores."18

O homem tem a tendência em considerar correto e natural o seu modo de vida em relação ao de outros grupos, julgando, desrespeitando e depreciando conseqüentemente os demais. Tal tendência, denominada etnocentrismo, é responsável em seus casos extremos pela ocorrência de numerosos conflitos sociais.

\begin{abstract}
Etnocentrismo - segundo a sua definição "o etnocentrismo é o termo técnico para esta visão das coisas segundo a qual nosso próprio grupo é o centro de todas as coisas e todos os outros grupos são medidos e avaliados em relação a ele [...] Cada grupo alimenta seu próprio orgulho e vaidade, considera-se superior, exalta suas próprias divindades e olha com desprezo as estrangeiras. Cada grupo pensa que seus próprios costumes são os únicos válidos e se ele observa que outros grupos têm outros costumes, encara-os com desdém. ${ }^{19}$
\end{abstract}

Já Jean Pierre Warnier define como etnocentrismo "a identificação normal de cada indivíduo com a sociedade à qual ele pertence e a valorização de sua própria cultura. Sob pena de ser marginalizado, todo indivíduo é, e deve ser em alguma medida, etnocentrista"20.

Laraia complementa dizendo que "o etnocentrismo, de fato, é um fenômeno universal. É comum a crença de que a própria sociedade é o centro da humanidade, ou mesmo a sua única expressão. As autodenominações de diferentes grupos refletem este ponto de vista" ${ }^{21}$.

\footnotetext{
${ }^{18}$ LIMA, Luiz Costa (Org.) Teoria da cultura de massa. p. 66.

${ }^{19}$ SIMON, Pierre-Jean apud CUCHE, Denys. Op. Cit.p. 46.

${ }^{20}$ WARNIER, Jean Pierre. Mundialização da cultura. p. 49.

${ }^{21}$ LARAIA, Roque de Barros. Op. Cit.p. 73.
} 
A mentalidade etnocêntrica gera comportamentos etnocêntricos, fazendo com que haja a tendência em depreciar as culturas, as civilizações diferentes, resultando em apreciações negativas dos padrões culturais de povos diferentes. Práticas de outros sistemas culturais são vistas como absurdas, deprimentes e imorais, e ainda são julgadas de modo pejorativo.

Como escreveu Lévi-Strauss, "os homens têm sempre dificuldade de encarar a diversidade das culturas como um fenômeno natural, resultante das relações diretas ou indiretas entre as sociedades" 22.

\subsubsection{Conceito de cultura renovado}

Nenhuma cultura existe em "estado puro", sempre igual a si mesma, sem ter jamais sofrido a mínima influência externa. O processo de aculturação é um fenômeno universal, mesmo que tenha formas e graus muito diversos.

"Toda cultura é um processo permanente de construção, desconstrução e reconstrução. O que varia é a importância de cada fase, segundo as situações"³.

\subsection{Dinamismo cultural}

Entender as diferenças que ocorrem dentro do mesmo sistema é fundamental para o homem enfrentar tranqüilamente as mudanças que estão por vir na esfera da cultura.

\footnotetext{
22 LEVI-STRAUSS, Claude Apud CUCHE, Denys. Op. Cit. p. 47.

${ }^{23}$ CUCHE, Denys. Op. Cit. p. 137.
} 
Entender esta dinâmica é importante para atenuar o choque entre as gerações e evitar comportamentos preconceituosos. Da mesma forma que é fundamental para a humanidade a compreensão das diferenças entre os povos de culturas diferentes, é necessário saber entender as diferenças que ocorrem dentro do mesmo sistema. Este é o único procedimento que prepara o homem para enfrentar serenamente este constante e admirável mundo novo do porvir. ${ }^{24}$

Com todo este dinamismo que envolve a cultura, Balandier nos remete a pensar que

Se a cultura não é um dado, uma herança que se transmite imutável de geração em geração, é porque ela é uma produção histórica, isto é, uma construção que se inscreve na história e mais precisamente na história das relações dos grupos sociais entre si. Para analisar um sistema cultural, é então necessário analisar a situação sóciohistórica que o produz como ele é. ${ }^{25}$

Segundo Laraia, existem dois tipos de mudança cultural: uma que é interna, resultante da dinâmica do próprio sistema cultural, e uma segunda que é externa, resultado do contato de um sistema cultural com outro.

No primeiro caso, resultante da dinâmica do próprio sistema cultural, a mudança pode ocorrer lentamente e o observador quase não percebe. Porém, o ritmo pode ser alterado por uma catástrofe, uma grande inovação tecnológica ou uma dramática situação de contato, ou seja, por eventos históricos.

O segundo caso pode ser mais rápido e brusco, devido ao contato entre as culturas, ocasionando mudanças de grande impacto. Como exemplo, o caso dos índios brasileiros que, ao estarem em contato com os colonizadores, tiveram sua cultura modificada, representando uma verdadeira catástrofe. Porém, pode também ser um processo menos radical, em que a mudança de padrões culturais ocorre sem grandes conseqüências.

\footnotetext{
${ }^{24}$ LARAIA, Roque de Barros. Op. Cit.p. 101.

${ }^{25}$ BALANDIER, Georges apud CUCHE, Denys. Op. Cit. p. 143.
} 
Este segundo tipo de mudança é o mais atuante e também o mais estudado na maior parte das sociedades humanas. É praticamente impossível imaginar a existência de um sistema cultural que seja afetado apenas pela mudança interna. Isto somente seria possível no caso, quase absurdo, de um povo totalmente isolado dos demais.

Essa mudança oriunda de causas externas sempre obteve grande atenção por parte dos antropólogos, que desenvolveram um esquema conceitual específico. Dentro desse esquema surge o conceito de aculturação, utilizado desde o início do século pela antropologia alemã e a partir de 1928 pelos antropólogos anglo-saxões, logo atingindo nosso meio acadêmico.

\subsubsection{Aculturação}

Em 1880, J. W. Powell, antropólogo norte-americano, parece ter criado o substantivo "aculturação", de acordo com Cuche; ele denominava "a transformação dos modos de vida e de pensamento dos imigrantes ao contato com a sociedade americana"26.

Tendo em vista o enorme volume de dados baseados em experiências e não nos estudos sobre a aculturação, o Conselho de Pesquisas em Ciências Sociais dos Estados Unidos, no ano de 1936, criou um comitê, a fim de organizar a pesquisa sobre os fatos de aculturação. Tal comitê, composto por Robert Redfield, Ralpdos Linton e Melville Herskovits, em seu célebre Memorando para o Estudo da Aculturação, começa por fazer um esclarecimento semântico. A definição que enuncia será a partir de então a regra: da dinâmica do próprio sistema cultural.

\footnotetext{
${ }^{26}$ CUCHE, Denys. Op. Cit. p. 114.
} 
Trata-se de aculturação quando duas culturas distintas ou parecidas são absorvidas uma pela outra, formando uma nova cultura diferente. Além disso, aculturação pode ser também a absorção de uma cultura pela outra, sendo que essa nova cultura terá aspectos da cultura inicial e da cultura absorvida. Para Cuche, "a aculturação é o conjunto de fenômenos que resultam de um contato contínuo e direto entre grupos de indivíduos de culturas diferentes e que provocam mudanças nos modelos culturais iniciais de um ou dos dois grupos"27.

No presente, dificilmente haverá uma sociedade que não tenha sentido o impacto de uma cultura diferente da sua.

De acordo com Titiev, o termo pode ser utilizado em relação a misturas totais ou parciais de quaisquer formas de vida.

Dá-se o nome de aculturação ao processo de mistura de culturas. Enquanto a idéia principal deste termo está estreitamente ligada à da difusão e enquanto o termo pode ser usado em relação a misturas totais ou parciais de quaisquer formas de vida diferentes, é mais geralmente aplicado ao estudo da influência da cultura Euroamericana num grupo não letrado e relativamente isolado. ${ }^{28}$

Laraia conclui que cada sistema cultural está sempre em mudança. É importante entender esse dinamismo do sistema cultural para evitar comportamentos preconceituosos e diminuir o conflito entre as gerações. O autor destaca a importância para os povos de compreender as diversidades culturais entre os diferentes grupos.

\subsubsection{Cultura e Identidade}

\footnotetext{
${ }^{27}$ CUCHE, Denys. Op. Cit. p. 115.

28 TITIEV, Mischa. Op. Cit. p. 177.
} 
$\mathrm{Na}$ percepção individual ou coletiva da identidade, a cultura exerce papel primacial para delimitar as diversas personalidades, os padrões de conduta e, ainda, as carcaterísticas próprias de cada grupo humano.

Para o teórico Milton Santos, o conhecimento e saber se renovam do choque de culturas, sendo a produção de novos conhecimentos e técnicas produto direto da interposição de culturas diferenciadas - com o somatório daquilo que anteriormente existia. Para ele, a globalização que se verificava já em fins do século $X X$ tenderia a uniformizar os grupos culturais, e logicamente uma das conseqüências seria o fim da produção cultural como geradora de novas técnicas e sua geração original. Isto refletiria, ainda, na perda de identidade, primeiramente das coletividades, podendo ir até ao plano individual.

Gallissot menciona que o conceito de cultura

obteve, há algum tempo, um grande sucesso fora do círculo estreito das ciências sociais, há, no entanto, um outro termo que é freqüentemente associado a ele - a "identidade" - cujo uso é cada vez mais freqüente, levando certos analistas a verem neste uso o efeito de uma verdadeira moda. ${ }^{29}$

Cuche complementa referindo que esta moda é o prolongamento do fenômeno de exaltação da diferença que surgiu nos anos 1970, levando tendências

${ }^{29}$ GALLISSOT, René apud CUCHE, Denys. Op. Cit. p. 175. 
ideológicas diversas e até opostas a fazer apologia da sociedade multicultural, ou seja, a exaltação da idéia de "cada um por si para manter sua identidade".

Não se pode, pura e simplesmente, confundir as noções de cultura e de identidade cultural, ainda que ambas tenham grande ligação. Em última instância,

cultura pode existir sem consciência de identidade, ao passo que as estratégias de identidade podem manipular e até modificar uma cultura que não terá então quase nada em comum com o que ela era anteriormente. A cultura depende em grande parte de processos inconscientes. A identidade remete a uma norma de vinculação, necessariamente consciente, baseada em oposições simbólicas. ${ }^{30}$

A memória coletiva, que se verifica quando um povo guarda suas características, seus valores. também é um elemento importante quando se pensa em identidade cultural. Muitos povos conservam a memória coletiva através das tradições, mantidas há gerações, garantindo, dessa forma, a sua identidade.

Stuart Hall, estudioso britânico da cultura, enfoca a questão identitária e a sua relação com as manifestações culturais, sob o alcance político-cultural do fenômeno globalização. Para o autor, a conceitualização de identidade cultural é interferida por este fenômeno.

O homem procura defender suas tradições, suas heranças culturais, pois é através delas que ele cria e recria sua própria cultura, seu modo de vida, seu mundo. A base em que se estruturam os processos de identidade está ligada com a valorização das raízes, das etnias e das raças, das religiões, da história partilhada, das expressões artísticas e das manifestações culturais, configurando a identidade como fonte de experiência de um povo.

Para Hall, simultaneamente ao poder da globalização neoliberal, verifica-se o encantamento pela beleza. Junto com o impacto global, surge um novo interesse

${ }^{30}$ CUCHE, Denys. Op. Cit. p. 176. 
pela diferenciação local. Assim, "ao invés de pensar o global, 'substituindo' o local seria mais acurado pensar numa nova articulação entre o 'global' e o 'local’’31

\title{
1.4.3 A concepção relacional e situacional
}

É no interior de contextos sociais, determinantes da posição dos agentes que orientam suas representações e suas escolhas, que se faz a construção de identidade. Para Cuche, a construção da identidade não é uma ilusão, pois é dotada de eficácia social, produzindo efeitos sociais reais.

\begin{abstract}
A identidade é uma construção que se elabora em uma relação que opões um grupo aos outros grupos com os quais está em contato. Deve-se esta concepção de identidade como manifestação relacional à obra pioneira de Frederik Barth [1969]. Esta concepção permite ultrapassar a alternativa objetivismo/subjetivismo. Para Barth, devese tentar entender o fenômeno da identidade através da ordem das relações entre os grupos sociais. Para ele, a identidade é um modo de categorização utilizado pelos grupos para organizar suas trocas. Também, para definir a identidade de um grupo, o importante não é inventariar seus traços culturais distintivos, mas localizar aqueles que são utilizados pelos membros do grupo para afirmar e manter uma distinção cultural. Uma cultura particular não produz por si só uma identidade diferenciada: esta identidade resulta unicamente das interações entre grupos e os procedimentos de diferenciação que eles utilizam em suas relações. ${ }^{32}$
\end{abstract}

Para se entender essa diferença dos grupos sociais e suas interações, é preciso primeiramente situá-los em um ambiente socioeconômico.

\subsection{Capitalismo e cultura de massa}

\footnotetext{
${ }^{31}$ HALL, Stuart. A Identidade Cultural na Pós-modernidade. p. 77

${ }^{32}$ CUCHE, Denys. Op. Cit. p. 182.
} 
Os fatores da arrancada e do triunfo da economia de mercado são: o desenvolvimento tecnológico, a racionalização contábil, a reorganização jurídica e político-administrativa harmonizadas e mão-de-obra forçada a vender sua força de trabalho; estes se integram aos mecanismos de produção, de controle, de expansão e repressão que caracterizam o capitalismo.

Nas palavras de lanni (1979), o capitalismo é um modo de produção material e intelectual.

\begin{abstract}
Seja para constituir-se e generalizar-se, seja para reproduzir-se e recriar-se continuamente, as relações capitalistas engendram idéias, noções, valores e doutrinas. Sem estes elementos intelectuais, isto é, da cultura espiritual, as relações de apropriação econômica e dominação política específicas do capitalismo não poderiam constituir-se nem substituir. As forças produtivas e as relações de produção características do capitalismo somente se concretizam e expandem num universo de valores, idéias, noções e doutrinas apropriado. $^{33}$
\end{abstract}

No capitalismo, a pessoa precisa se situar no processo produtivo. Para isso, desvincula-se do Estado e vincula-se a uma classe social, a partir da posição que ocupa no processo produtivo. Circula livremente como cidadã de uma nação, mas para isso deve estar a serviço das regras do mercado de força de trabalho e do principio de propriedade privada.

\title{
1.5.1 A residência da cultura de massa
}

Não foi suficiente, portanto, a arrancada do sistema capitalista, o incremento da velocidade da comunicação, o aparecimento dos primeiros meios de reprodução

\footnotetext{
${ }^{33}$ IANNI, Octavio. Imperialismo e cultura. p. 22.
} 
técnica e a baixo preço para que já se desse a cultura de massa. Os mass media já existem, criados como veículos da cultura de massa, e aprendem o jeito de cativar a tudo e a todos. O que inexiste é a integração inconsciente de suas mensagens numa modalidade de cultura.

Lima defronta-se com a residência histórica da cultura de massa e relata.

\begin{abstract}
Assim como o desenvolvimento tecnológico desempenhou um dos requisitos básicos na constituição do capitalismo, assim também, no campo da CM, são decisivos os desenvolvimentos realizados nos processos de comunicação, desde o princípio do século até as décadas mais recentes. A comunicação agora deixa de ser basicamente verbal, escrita e/ou literária para tornar-se, utilizando a aglutinação joyceana verbo-voco-visual. Tecnicamente, passamos à era da comunicação multidirecional. A mensagem perde seu caráter de parcelada, distribuída em pontos reconhecidos (teatro, biblioteca, museu, sala de cursos, de projeção), por instrumentos reconhecidos (jornal, livro, revista, gravura, cartaz), que se podem evitar ou escolher. ${ }^{34}$
\end{abstract}

Dessa maneira, todos os instrumentos de transmissão de informações e conhecimentos são envolvidos no processo de comercialização.

Segundo lanni,

as idéias, as noções, os valores, os princípios e as doutrinas que codificam a visão burguesa do mundo passam a ser produzidos e multiplicados, em escala industrial e mundial, para atender às exigências da reprodução ampliada do capital. O jornal, a revista, o livro, os folhetins, a música popular, o filme, o rádio, a televisão, o teatro, a escola, todos os instrumentos e as agências de transmissão de informações e conhecimentos são envolvidos no amplo processo de comercialização de mercadorias culturais. ${ }^{35}$

\footnotetext{
${ }^{34}$ LIMA, Luiz Costa (Org.) Op. Cit.. p . 43.

35 IANNI, Octavio. Op. Cit.. p. 26.
} 
Esse é um dos motivos pelos quais muitos autores se atêm a estudar a questão do consumo da cultura produzida pelas mass media. Tais autores também concluem que existe um nivelamento cultural entre os grupos sociais, o que acarreta a uniformização cultural, e que seria ela própria a conseqüência da generalização dos meios de comunicação de massa.

Para Canclini, a cultura relaciona-se com o consumo, e este, por sua vez, influencia a formação das identidades de classes. Para tanto, o autor define o consumo da seguinte forma:

a) o consumo é o lugar de reprodução da força do trabalho e de expansão do capital. As necessidades estão organizadas de acordo com os interesses das classes hegemônicas;

b) o consumo é o lugar onde as classes lutam pela apropriação do produto social, um lugar onde os conflitos emergem originados pelas desigualdades;

c) o consumo é o lugar de diferenciação social e distinção simbólica entre as classes, uma área fundamental para construir e comunicar as diferenças entre os grupos. A diferença se produz não só pelos objetos que possuem, mas também pela forma de usá-los: a escola dos filhos, os rituais de alimentação, os programas que assistem, pelo design, pela forma de apropriá-lo;

d) consumo é um sistema de integração e comunicação; consumir é intercambiar significados sociais e culturais e através das coisas é possível criar relações entre as pessoas. Somos reconhecidos e identificados conforme os objetos que possuímos;

e) o consumo é o lugar de objetivação do desejo. Além das necessidades culturalmente elaboradas, atuamos perseguindo os desejos sem objetos, impulsos que não levam à posse de coisas precisas ou em relação às pessoas físicas. ${ }^{36}$

Assim, Garcia Canclini redefine o conceito de consumo, por meio do qual referenciam-se as interações sociais. É na vida cotidiana, antigamente vista como espaço de reprodução da força de trabalho, que se produz ativamente a sociedade, construindo sentidos e cultura. Nos modos de interação a comunicação é efetivada,

\footnotetext{
${ }^{36}$ CANCLINI, Néstor GARCÍA y RONCAGLIOLI, Rafael. Op. Cit.. p. 49.
} 
não só com as mensagens, mas com a sociedade, de sujeito para sujeito, com outros atores sociais.

Ainda relacionando a cultura com o consumo, Baudrillard, com sua noção de cultura simulacional e analisando a cultura como arte no pós-modernismo, salienta que

as mercadorias de consumo no capitalismo desenvolveram a capacidade de incorporar associações imagéticas e simbólicas transformando-se em mercadorias-signos. Para o autor a cultura é apresentada em meio aos demais objetos de consumo, como acessório de luxo, transformada em substância lúdica. Afinal é possível oferecer, no mesmo grande e irresistível espaço, lanche, vestido, curso de idiomas, tratamento estético, disco, flores, cinema e livros, enfim, um pouco de tudo. Para especificarmos ainda mais, no mesmo espaço - uma banca de jornal, por exemplo - é possível encontrar jornal, revista em quadrinhos, publicação sobre sexo, livro de bolso, dicionário, revista de variedades, livro de arte e livro de idéias. $\mathrm{O}$ autor atribui o termo culturalizar substituindo o prostituir (a cultura) nesse afã de consumo. ${ }^{37}$

Outra preocupação com a cultura em meio ao consumo é a sua forma de manufatura, pois os veículos de comunicação importam pela quantidade que trazem à circulação e não pela qualidade.

Os mass media, como qualquer veículo de comunicação cultural, estabelecem quantidades, importam pela quantidade que trazem à circulação; a cultura que os integra estabelece qualidade importada pelo valor que socialmente se the confere. ${ }^{38}$

Na opinião de Strinati a arte não pode ser produzida por meio de formas de manufatura rotineira, seriadas, especializadas e fragmentadas, como os produtos da

\footnotetext{
${ }^{37}$ BAUDRILLARD, Jean. Simulacros e Simulação. p. 104

${ }^{38}$ LIMA, Luiz Costa (Org.) Op. Cit.. p . 22.
} 
cultura de massa, padronizados e repetitivos. A sua criatividade, sua experimentação, sua complexidade estética e seu propósito intelectual não podem ser obtidos por técnicas que produzem a cultura de massa. O artista tem de trabalhar sem as restrições do mercado, das técnicas padronizadas de composição e das fórmulas testadas e aprovadas.

Ultimamente, o que se pode ver são produtos de baixa qualidade, uma cultura consumida através dos veículos de comunicação de massa: televisão, jornais, rádio, cinema, propaganda. Para ser consumido pela massa, é preciso ser nivelado por baixo, ou seja, cultura de fácil entendimento, o que é traduzido pelos mais intelectualizados por baixa qualidade.

Um dos motivos desse baixo nivelamento é conferido à questão da hegemonia.

Os estudos de Canclini também enfocam uma substituição da teoria da dominação pela teoria da hegemonia, contribuindo significativamente para o estudo da cultura e da sociedade.

Para o autor, "a cultura é o conjunto de processos onde se elabora a significação das estruturas sociais, onde se as reproduz e transforma mediante operações simbólicas". ${ }^{39}$

Com a idéia de que a cultura hegemônica pressupõe dominação e a cultura subalterna, resistência, na década de 1990, devido ao avanço dos movimentos políticos alternativos, as pesquisas se detinham em averiguar como uma e outra cultura desempenhavam os seus papéis, fomentando uma visão oposta das décadas de 1970 e 1980.

\footnotetext{
${ }^{39}$ CANCLINI, Néstor GARCÍA y RONCAGLIOLI, Rafael. Cultura Transnacional y Culturas Populares. p. 29
} 
Para sair desse impasse, o referido autor sugeriu uma outra teoria, ou outros recursos metodológicos, o que se chama de oposição/dominação.

Nessa perspectiva, o campo da cultura e da comunicação não pode ser visto meramente com um espaço de exercício unilateral, total e sem espaço de reelaboração.

\subsubsection{Cultura de massa}

A noção de cultura de massa obteve um grande sucesso na década de 1960. Segundo Cuche,

Este sucesso deveu-se, em parte, à sua imprecisão semântica e à associação paradoxal, do ponto de vista da tradição humana, dos termos "cultura" e "massa". Não é surpreendente que esta noção tenha sido utilizada para embasar análises de orientação sensivelmente diferentes. ${ }^{40}$

Strinati conceitua cultura de massa como "uma cultura padronizada, repetitiva e superficial, que celebra os prazeres banais, sentimentais, imediatos e falsos em detrimento dos valores sérios, intelectuais, tradicionais e autênticos". ${ }^{41}$

Consideram-se importante as observações de Leavis de que

[...] ao contrário da cultura folk, a cultura de massa recusa-se a permanecer em seu devido lugar. Restrita às massas, manifesta pretensões que vão além de sua posição ou mérito, e não reconhece nem hierarquias estéticas tradicionais, nem distinções culturais produzidas pela elite. ${ }^{42}$

\footnotetext{
${ }^{40}$ CUCHE, Denys. Op. Cit. p. 157.

${ }^{41}$ STRINATI, Dominic. Cultura popular: uma introdução. p. 30.

42 LEAVIS, Q. D. apud STRINATI, Dominic. Op. Cit. p. 32.
} 
Branco explica que a produção da cultura de massa é de poucos para muitos, ou seja, produzida por poucas pessoas e difundida para muitas, e relata também a diferença entre os três sistemas culturais no que diz respeito à concepção de tempo.

\begin{abstract}
A cultura de massa envolve a eletro-eletrônica e sua produção é de poucos para muitos. Contudo, a principal diferença entre os três sistemas culturais diz respeito à concepção de tempo. A cultura erudita tem o tempo de reflexão, onde pode-se voltar a datas e, exemplificando, estudar o surgimento do primeiro jornal impresso para grande público no mundo. O tempo cíclico, característico da cultura popular, se repete porque está atrelado à natureza, ao cotidiano, como é o caso do tempo do ciclo agrário, da semeadura à ceifa, com pausa para o descanso da terra. A cultura de massa é marcada pelo tempo acelerado, pois é o tempo do consumo: a lei do maior número, no menor espaço de tempo e com o maior lucro possível. ${ }^{43}$
\end{abstract}

Bosi explica que o tempo acelerado lesa o consumidor sem meios de defesa gerando a perda de memória social de forma que as informações não são absorvidas pelos homens da forma que deveriam, afirmando ser a cultura de massa

colonizadora nos seus processos e nos seus centros de origem ao invadir, ocupar e administrar o tempo do relógio e o tempo interior do cidadão, pouco the importando as fronteiras nacionais. O autor observa que o tempo acelerado traz a perda de memória social generalizada, a qual lesa o consumidor sem meios de defesa e reforça essa posição com o fato de que as imagens da televisão são projetadas no cérebro do telespectador de forma a este não ter tempo de absorvê-las. Tudo consiste na urgência da substituição que gera o caráter descartável do signo dentro do regime industrial avançado. $^{44}$

Para Milton Santos,

\footnotetext{
${ }^{43}$ BRANCO, Samantha Castelo. Cultura popular $X$ cultura de massa: onde Judas não perdeu as botas. Anais do V Congresso Latino-Americano de Ciências da Comunicação. Santiago do Chile: 2000

${ }^{44}$ BOSI, Alfredo apud BRANCO, Samantha Castelo. Op. Cit.. p. 08.
} 
a globalização neoliberal domina a velocidade e a fluidez virtual, promovidas pelos avanços da técnica, principalmente, pelos sistemas de informação. A fluidez forma-se no imaginário e na ideologia como se fosse um bem comum, uma fluidez para todos, quando, na verdade, serve apenas a algumas empresas, agentes que têm a possibilidade de usá-la e de controlá-la, tornando-se "donos" da velocidade e da circulação rápida e incessante de informações e, conseqüentemente, das imposições do mercado. ${ }^{45}$

\subsubsection{Crítica à teoria da cultura de massa}

Existe uma teoria que afirma que a cultura popular ou de massa só pode ser analisada e interpretada com base nos critérios advindos da cultura erudita, derivados da estética das elites culturais e intelectuais. Uma posição um tanto elitista de cultura.

Strinatti salienta que "é característico das elites tentarem impingir seu próprio gosto como o melhor, ou como o único padrão de análise da cultura popular. ${ }^{46}$

No entanto, conclui-se que o modo elitista de conceber a cultura acaba por considerá-la uma cultura de massa homogênea ou padronizada.

Embora a cultura de massa use às vezes formas padronizadas, isso não Ihe é exclusivo, já que ocorre igualmente na cultura erudita. Além disso, é perfeitamente possível apreciar certas formas de cultura de massa ou de cultura popular sem aceitá-las totalmente. Uma vez que a cultura popular não é homogênea, não precisa ser consumida como um todo. Certas partes podem ser escolhidas seletivamente, como resultado de fatores sociais e culturais mais precisos do que os considerados pela cultura de massa. ${ }^{47}$

\footnotetext{
${ }^{45}$ SANTOS, Milton. Por uma Outra Globalização - do pensamento único à consciência universal. p. 105.

${ }^{46}$ STRINATI, Dominic. Op. Cit... p. 51.

${ }^{47}$ Ibid. p. 52 e 53.
} 
Strinati distinguiu cultura de massa de cultura erudita como algo que ainda não possui um antagonismo muito claro e firme como outros teóricos apontam. Os limites traçados entre estas duas culturas, segundo ele, são constantemente desafiados e reconsiderados. Tais limites não possuem total consistência em sua objetividade nem podem ser considerados constantes, acabando por configuraremse como limites duvidosos, descontínuos e desfavoráveis.

Para Mac Donald, "a cultura de massa é homogênea, degradante e tem a capacidade de refazer a sua própria imagem. Por isso representa uma ameaça". ${ }^{48}$

Assim, considera-se importante esclarecer duas posturas em relação à cultura de massa.

A primeira, a corrente otimista, pode ser observada no pensamento de Marshall McLuhan, que "defende a emancipação do homem através da presença dos meios de comunicação de massa, já que essa é democrática, atingindo muitos indivíduos. Como explicitado no início desse trabalho".49

Já Adorno, representando a segunda corrente, "analisa com pessimismo o advento dos meios de comunicação de massa, prevendo uma perda na qualidade do homem, quando o consumidor, ao contrário de ser sujeito, passa a ser objeto na indústria cultural”. 50

\subsubsection{A preocupação social com os mass media}

Existem algumas preocupações com os mass media. Uma delas é a facilidade que estes podem estar em vários lugares ao mesmo tempo; outra referese à forma pela qual estes serão utilizados. De acordo com Merton e Lazarsfeld,

\footnotetext{
${ }^{48}$ MAC DONALD apud STRINATI, Dominic. Op. Cit. p. 31.

${ }^{49}$ BRANCO, Samantha Castelo. Op. Cit.. p. 06.

${ }^{50}$ Ibid. p. 06.
} 
Muitos se preocupam com a ubiqüidade e poder em potencial do mass media. Sente-se, geralmente, que os mass media contêm um poderoso instrumental que poderá ser utilizado para o bem ou para o mal e que, na ausência de controles adequados, a última possibilidade apresenta-se como o mais provável [...]. ${ }^{51}$

Merton e Lazarsfeld referem-se também aos tipos de controle social que poderosos grupos de interesse exercem na sociedade. Os principais grupos de poder vêm adotando técnicas para manipular o público de massa através propaganda.

A ubiqüidade dos mass media nos leva prontamente à crença, quase mágica, em seu enorme poder. Mas existe outra base, talvez mais realista, para esta ampla preocupação com o papel social dos mass media. Referimo-nos aos diversos tipos de controle social que poderosos grupos de interesse exercem na sociedade. Cada vez mais, os principais grupos de poder, entre os quais o mundo do negócio organizado ocupa posição de maior destaque, vêm adotando técnicas para manipular o público de massa pela propaganda, ao invés de empregar meios mais diretos de controle. As organizações industriais não mais obrigam a criança de oito anos estar a serviço de uma máquina durante 14 horas por dia. Ao invés disto, preocupam-se com requintados programas de "relações públicas"; colocam extensos anúncios de grande impacto nos jornais do país; patrocinam numerosos programas radiofônicos; organizam competições à base de prêmios, sob orientação de conselheiros de relações públicas; estabelecem fundações de beneficência e apóiam as causas meritórias. O poder econômico parece ter reduzido a exploração psicológica alcançada em grande parte pela propaganda disseminada pelos mass media. ${ }^{52}$

Esses pontos relacionados por Merton e Lazarsfeld constituem dois dos três elementos da preocupação com os mass media. O terceiro elemento resulta do perigo que os instrumentos de comunicação de massa levem à deterioração dos gostos estéticos e dos padrões culturais populares.

\footnotetext{
${ }^{51}$ MERTON, Robert K. e LAZARSFELD, Paul F.. Comunicação de massa, gosto popular e a organização da ação social. In: LIMA, Luiz Costa. Teoria da Cultura de massa. p. 109.

${ }^{52}$ MERTON, Robert K. e LAZARSFELD, Paul F.. Op. Cit.. p. 110.
} 
Em primeiro lugar, muitos temem a ubiqüidade e o poder em potencial desses meios. Temos sugerido que isto se assemelha ao medo indiscriminado de um fantasma, e provém de uma posição social insegura e de valores tenuamente mantidos. A propaganda mostra-se ameaçadora.

Existe, em segundo lugar, a preocupação com os atuais efeitos dos mass media sobre seu enorme público e, mais especificamente, com a possibilidade de que seu contínuo assalto leve à entrega incondicional da capacidade crítica do público a seu inconsciente conformismo.

Finalmente, existe o perigo de que esses instrumentos de comunicação de massa, tecnicamente avançados, levem à seria deterioração dos gostos estéticos e dos padrões culturais populares. Temos também sugerido que existem razões significativas para preocupação com os efeitos sociais imediatos dos mass media. ${ }^{53}$

\subsubsection{Efeitos sobre a cultura e o gosto popular}

Como referido anteriormente, existe uma grande preocupação com o papel social dos meios de comunicação de massa, o qual supostamente produz efeito sobre a cultura popular e o gosto estético de seu público.

"Tem-se afirmado que, à medida que a assistência aumenta, o nível do gosto estético tem decaído. Teme-se que, propositadamente, os mass media acatam tais gostos vulgarizados, assim contribuindo para uma decadência cada vez maior" ${ }^{\text {54 }}$.

Não há consenso a respeito do gosto popular. Alguns têm confiança no instinto do povo para o bom, mas a concepção predominante parece ser que apenas o ruim e o vulgar funcionam como elementos de medida para o seu prazer estético.

Alguns séculos atrás, a platéia da arte era limitada a uma elite aristocrática selecionada. Uma pequena fração da população cultivava seus gostos estéticos, deixando uma marca na forma de padrões artísticos.

\footnotetext{
53 MERTON, Robert K. e LAZARSFELD, Paul F.. Op. Cit.. p. 111.

${ }^{54}$ MERTON, Robert K. e LAZARSFELD, Paul F.. Op. Cit.. p. 110.
} 
Se os gostos estéticos devem ser considerados em seu cenário social, precisamos reconhecer que a efetiva platéia da arte se transformou historicamente. Alguns séculos atrás, essa platéia se restringia a uma elite aristocrática selecionada. Relativamente poucos eram literatos. E muitos poucos possuíam meios de comprar livros, assistir peças de teatro e viajar para centros artísticos. Não mais do que uma pequena fração, possivelmente não mais do que $1 \%$ ou $2 \%$ da população, compunha o público efetivo da arte. Esses poucos felizardos cultivavam seus gostos estéticos e sua demanda seletiva deixou uma marca na forma de padrões artísticos, relativamente altos. ${ }^{55}$

Dessa forma, desenvolveu-se um grande mercado para a arte com o surgimento de novas tecnologias de comunicação de massa e com a ampliação extensiva da educação popular. Algumas formas de música, drama e literatura agora praticamente alcançam a todos em nossa sociedade.

Em decorrência desse fator, a elite, que ontem compunha praticamente o total da platéia de arte, hoje é uma fração muito pequena, o que fez decrescer o nível dos padrões estéticos e de gosto da audiência.

Nossa formulação do problema deve ser agora evidenciada. É enganador falar-se simplesmente de declínio e gosto estético. As platéias de massa provavelmente incluem uma proporção maior de pessoas com padrões estéticos desenvolvidos, porém ela é tragada pela grande massa que constitui a nova e inculta platéia de arte. Enquanto a elite ontem constituía praticamente o total da platéia, ela é hoje uma fração diminuta do conjunto. Em decorrência, o nível médio dos padrões estéticos e de gosto da audiência decresceu, embora o gosto de alguns setores da população, indubitavelmente, se apurou e a soma geral de pessoas expostas aos conteúdos da comunicação tenha aumentado de modo sensível. ${ }^{56}$

\footnotetext{
${ }^{55}$ MERTON, Robert K. e LAZARSFELD, Paul F.. Op. Cit.. p. 123.

${ }^{56}$ MERTON, Robert K. e LAZARSFELD, Paul F.. Op. Cit. p. 124.
} 
Assim, pode-se dizer que o mass media tem um impacto sobre o gosto popular, uma vez que a maior parte de nossos programas de rádio, cinema, revistas e uma considerável parte de nossos livros e jornais se dedicam ao entretenimento.

No entanto, existe uma resistência profunda por parte da platéia de massa em relação à elevação dos padrões culturais. Estações de rádio em cadeias tentaram suplantar a novela com programas de música erudita ou comédias padronizadas por discussões a respeito das questões públicas. Em geral, as pessoas que poderiam ser beneficiadas por essa reformulação dos programas simplesmente se recusam a ser beneficiadas.

\title{
1.6 As culturas populares
}

Existem várias definições para o termo cultura popular. Cuche trata da dificuldade em debater sobre este assunto, pois nem todos os autores atribuem a mesma definição para o termo. Segundo o autor,

\begin{abstract}
A noção de cultura popular tem, desde sua origem, uma ambigüidade semântica, devido à polissemia de cada um dos dois termos que a compõe. Nem todos os autores que recorrem a esta expressão dão a mesma definição ao termo "cultura" e/ou "popular". O que torna o debate entre eles bastante difícil. ${ }^{57}$
\end{abstract}

Tomando-se a definição de Canclini, o popular é próprio das classes subalternas e caracteriza-se como espaço no qual coexistem concepções do mundo herdadas do passado - tradições - e elementos modernizantes, do mundo em formação, como conseqüência das atuais condições de vida das classes subalternas.

${ }^{57}$ CUCHE, Denys. Op. Cit. p. 147. 
A cultura popular é muitas vezes confundida com folclore; no entanto, a cultura popular, como folclore, recupera invariavelmente a idéia de "tradição", seja na forma de tradição-sobrevivência, seja na perspectiva de memória coletiva que age dinamicamente no mundo da práxis. Segundo Fernandes, "Esta ênfase no caráter tradicional do patrimônio popular implica, na maioria das vezes, uma posição conservadora diante da ordem estabelecida." 58

Florestan Fernandes aponta este caráter conservador ao considerar o folclore uma necessidade histórica da burguesia européia. Para o autor, definir a cultura popular como o saber tradicional das classes subalternas das nações civilizadas seria assimilá-lo imediatamente à dimensão de atraso, legitimando a existência de uma dicotomia estrutural da sociedade - por um lado, ter-se-ia uma elite que se consolidaria como fonte e promulgadora do "progresso"; por outro, as classes subalternas, representando a permanência de formas culturais que arqueologicamente se acumulariam como legado de um passado distante.

Para Ortiz, o conceito de cultura popular se confunde com a idéia de conscientização; revoluciona, dessa forma, o antigo significado que assimilava a tradição à categoria de cultura popular.

'Cultura popular' não é, pois, uma concepção de mundo das classes subalternas, como o é para certos folcloristas que se interessam pela "mentalidade do povo", nem sequer os produtos artísticos elaborados pelas camadas populares, mas um projeto político que utiliza a cultura com elemento de sua realidade. ${ }^{59}$

Pode-se trabalhar também com o conceito apresentado por Oliveira:

\footnotetext{
${ }^{58}$ FERNANDES, Florestan. Sobre o Folclore. In: O folclore em Questão. p. 38.

${ }^{59}$ ORTIZ, Renato. Cultura Brasileira e Identidade Nacional. p. 72.
} 
a cultura é um componente essencial para o desenvolvimento de um povo, pois é através dela que os indivíduos compõem a sociedade, participam e contribuem para o bem coletivo. Para a autora são as manifestações culturais que apontam as características peculiares de determinada comunidade.

A cultura popular é aquela criada pelo povo e apoiada numa concepção de mundo específica e tradicional para seus criadores. Ela existe e se mantém através de manifestações populares de seus produtos culturais que só é possível através de ainda que mínimo um suporte organizacional, financeiro e comunicacional. ${ }^{60}$

Desenvolvendo a idéia de resistência sistemática à dominação, Michel de Certeau define a cultura popular como "a cultura 'comum' das pessoas comuns, isto é, uma cultura que se fabrica no cotidiano, nas atividades ao mesmo tempo banais e renovadas a cada dia"61.

Para Chauí, a cultura popular é construída por práticas efetuadas dentro de uma cultura dominante, estando esta de acordo ou não, podendo apropriar-se ou a ela resistir. Percebe-se, devido a estas e outras informações, que sempre foi alvo de estudiosos o processo de comunicação, que envolve as manifestações culturais; no entanto, "foi Luiz Beltrão quem mais se preocupou com os agentes da cultura popular na decodificação dos modos de pensar, sentir e agir que a mídia de massa dissemina todos os dias". 62

Complementando com Cuche, toda cultura particular é uma reunião de elementos originais e importados, heterogêneos, construídos em uma situação de dominação. De acordo com o autor,

As culturas populares revelam-se, na análise, nem inteiramente dependentes, nem inteiramente autônomas, nem pura imitação, nem

${ }^{60}$ OLIVEIRA, Maria José. Benditos sejam: resgate histórico sobre os cordelistas malditos de Juazeiro do Norte. Anais do XXVI Congresso Brasileiro de Ciências da Comunicação - Intercom. Belo Horizonte, 2003.

${ }^{61}$ CERTEAU, Michel de apud CUCHE, Denys. Op. Cit.. p 150.

${ }^{62}$ CHAUÍ, Marilena apud BENAJMIN, Roberto. Cachaça e rapadura, símbolos da comunicação popular em Areia - Paraíba - Brasil. Anais do V Congresso Latino Americano de Ciências da Comunicação, ALAIC, Chile, 2000. 
pura criação. Por isso, elas apenas confirmam que toda cultura particular é uma reunião de elementos originais e de elementos importados, de invenções próprias e de empréstimos. Como qualquer cultura, elas não são homogêneas sem ser, por esta razão, incoerentes. As culturas populares são, por definição, culturas de grupos sociais subalternos. Elas são construídas então em uma situação de dominação $[\ldots]^{63}$

Mas os grupos populares nem sempre estão confrontados ao grupo

dominante, o que permite uma atividade de simbolização original nos momentos em que esses grupos se encontram "a sós".

Ao darmos demasiada atenção ao que as culturas populares devem ao fato de serem culturas de grupos dominados, corremos o risco de minimizarmos de maneira excessiva sua relativa autonomia. Heterogêneas, estas culturas são em certos aspectos mais marcadas pela dependência em relação à cultura dominante e, ao contrário, em outros aspectos, mais independentes. E isto se dá porque os grupos populares não estão sempre e em toda parte confrontados ao grupo dominante. Nos lugares e nos momentos em que eles se encontram "a sós", o esquecimento da dominação social e simbólica permite uma atividade de simbolização original. De fato, é o esquecimento da dominação e não a resistência à dominação que torna possíveis as atividades culturais autônomas para as classes populares. ${ }^{64}$

\subsection{Cultura brasileira}

Para referir a cultura brasileira, é preciso entendê-la como heterogênea, uma cultura de caráter plural, resultante de um processo de múltiplas interações e oposições no tempo e no espaço.

Segundo Branco, pode-se, daí, dizer que,

em certos momentos, a cultura de massa, a cultura popular e a cultura erudita encontram-se. $\mathrm{O}$ contato étnico e a posterior mistura

\footnotetext{
${ }^{63}$ CUCHE, Denys. Op. Cit.. p. 148.
}

${ }^{64}$ CUCHE, Denys. Op. Cit. p. 156. 
iniciada com a colonização brasileira possibilitam hoje um Brasil de fusão com culturas antigas, como as ibéricas, indígenas e africanas, além de outras mais recentes: as culturas migrantes ou externas (italiana, alemã, síria, japonesa...) e as internas (nordestina, paulista, gaúcha... $)^{65}$.

O processo de mundialização da civilização européia foi definitivo para a formação histórica brasileira e fundamental para que a cultura nacional tivesse esse caráter plural.

Furtado enumera alguns episódios:

O deslocamento da fronteira agrícola do Velho Continente para as terras americanas, o transplante intercontinental de grandes massas de mão-de-obra africana, a implantação de linhas regulares de comércio interoceânicas são episódios de um processo histórico sem precedentes, que tem seu epicentro na Europa ocidental e serve de moldura à formação do Brasil como nação e como sistema de cultura. ${ }^{66}$

A cultura brasileira é um dos múltiplos frutos desse processo de mundialização do desdobramento geográfico da civilização européia a partir do início de século XVI. Tem, contudo, a particularidade de integrar-se na área de ação imediata de Portugal. ${ }^{67}$

No período colonial, os indígenas e os africanos, estes trazidos ao Brasil como força de trabalho, tiveram suas culturas modificadas. Por outro lado, os portugueses representavam o menor número; entretanto, foram os que mais influenciaram no processo de formação da cultura brasileira, não pelo fato de estarem em uma posição dominante, mas por utilizarem técnicas mais avançadas e, principalmente, por terem sido os únicos a manter suas origens culturais. "Ora, os aborígenes e os africanos haviam sido isolados de suas matrizes culturais

\footnotetext{
${ }^{65}$ BRANCO, Samantha Castelo. Op. Cit. p. 06

${ }^{66}$ FURTADO, Celso. Cultura e desenvolvimento em época de crise. p. 17.

${ }^{67}$ Ibid. p. 18.
} 
respectivas e, ao serem posteriormente privados das próprias línguas, perdiam o senso da identidade cultural"68, assim lembra Furtado.

Durante os séculos que marcaram o período colonial, desenvolveu-se no Brasil uma cultura portuguesa que incorporava não apenas motivos locais, mas também toda uma série de idéias de valores das culturas dos povos dominados. $\mathrm{O}$ Estado e a Igreja ocupavam um espaço significativo na sociedade, porém, a expressão mais forte da nova cultura apresentava-se na arquitetura e na escultura.

A ruptura da síntese barroca diante da modernização conduziu a padrões de comportamentos imitativos e não a um processo criativo. As elites, hipnotizadas, baseavam nos centros de cultura européia, de onde brotava o fluxo de bens de consumo. Naquela época o distanciamento entre elite e povo era a característica mais marcante do quadro cultural.

Mesmo desprezado pelas elites, o povo continuava seu processo de formação com certo grau de autonomia, permitindo que as raízes não européias de sua cultura se firmassem e que sua força criativa se expandisse menos inibida, comparando-se com a cultura da classe dominante. A diferenciação regional do Brasil deve-se essencialmente à autonomia criativa da cultura de raízes populares.

Segundo Furtado,

A ascensão da economia norte-americana, impulsionando uma cultura de massas dotada de meios extraordinários de difusão, opera contra esse fundo como principal fator de desestabilização do quadro cultural baseado na dicotomia elite-povo. ${ }^{69}$

\footnotetext{
68 Ibid. p. 21.

${ }^{69}$ FURTADO, Celso. Op. Cit.. p. 24.
} 
Mas é o desenvolvimento de uma classe média de importância econômica crescente que introduzirá elementos novos de peso na equação do processo cultural brasileiro.

\begin{abstract}
A classe média forma-se no quadro da modernização dependente, mediatizada por uma industrialização que segue as linhas da substituição de importações. Contudo, a grande maioria de seus elementos está demasiado próxima do povo para poder ignorar a significação cultural deste. Mais ainda: o caráter de massa da cultura da classe média faz que suas relações com o povo sejam não de exclusão, como era o caso das elites bovaristas, e sim de envolvimento e penetração. Desta forma, a ascensão da cultura da classe média é o fim do isolamento do povo, mas também o começo da descaracterização deste como força criativa. ${ }^{70}$
\end{abstract}

Os valores culturais de origem popular só foram reconhecidos depois desta emergência da consciência crítica na classe média, tornando possível a criação de áreas de resistência ao processo de descaracterização.

As elites, em certos momentos, desvalorizam a cultura brasileira, substituindoa pela cultura européia (ou mais recente a norte-americana) tornando-as modelo. "Como reação, em outros momentos nota-se que certas manifestações da cultura brasileira passam a ser profundamente valorizadas, exaltando-se símbolos como Macunaíma, a figura do malandro, o carnaval, o samba, o futebol, etc."71

A escolha do tipo social considerado representativo da nacionalidade e a capacidade de determinar o que é considerado cultura remete à questão paralela de decidir quem são os produtores válidos da cultura brasileira.

De acordo com Oliven,

uma primeira perspectiva tende a considerar como cultura brasileira tão somente aquelas manifestações intelectuais e artísticas da elite. Uma perspectiva pretensamente alternativa tende a valorizar as

\footnotetext{
${ }^{70}$ FURTADO, Celso. Op. Cit.. p. 24.

${ }^{71}$ OLIVEN, Ruben George. A relação estado e cultura no Brasil: cortes ou continuidade? In: MICELI, Sérgio. (Org.) Estado e cultura no Brasil. p. 43.
} 
manifestações culturais das classes dominadas como as verdadeiras raízes de nossa nacionalidade. Mas esta valorização é feita sob uma ótica nostálgica e frequentemente ufanista. Assim, parte de nossa intelectualidade apressa-se em "defender" a cultura popular dos ataques que o progresso estaria the desferindo, adotando uma postura paternalista e essencialmente museológica. ${ }^{72}$

\section{Segundo o autor,}

em verdade o que se percebe é que no primeiro tipo de colocação proclama-se a existência de uma Cultura Brasileira com "c" maiúsculo, que, embora produzida por apenas um grupo social restrito, seria válida para toda a nação e, inversamente, no segundo tipo de colocação erigi-se uma imagem cristalizada das manifestações culturais que nossas classes subalternas teriam desenvolvido no passado. ${ }^{73}$

Fica implícito que há uma dicotomia de cultura num único lugar. O que estas perspectivas não conseguem perceber é que existe uma relação entre as classes sociais no processo de produção cultural. Não se trata de simplesmente considerar que a cultura da classe dominante é cultura dominante, mas entender que existe um processo de apropriação e reelaboração cultural. Este processo é complexo e convém explicitá-lo.

Assim, em certos momentos, o que é considerado cultura brasileira é a apropriação e reelaboração por parte de nossas classes dominantes de traços culturais gerados nas metrópoles, traços que são tidos como os únicos dignos e com condições de serem adotados pelas elites.

Parece que o movimento modernista de 1922, com toda sua complexidade e diferenciação ideológica, representa um divisor de águas neste processo. Por um lado significa a reatualização do Brasil em relação aos movimentos culturais e artísticos que ocorrem no

\footnotetext{
72 Ibid. p. 44.

73 OLIVEN, Ruben George. Op. Cit.. p. 44.
} 
exterior; por outro lado implica também em buscar nossas raízes nacionais valorizando o que haveria de mais autêntico no Brasil. $^{74}$

A imagem que é proposta é a de uma cultura tropical com características totalmente diferentes das de outros países. Em contrapartida nota-se também um processo contrário, através do qual manifestações culturais, que se originam nas classes populares (dominadas) e que são inclusive às vezes reprimidas logo de início, são apropriadas pelas classes dominantes, muitas vezes sofrem um processo de manipulação de seu significado, e acabam transformadas em símbolos nacionais. Exemplos disso são o samba, o tema da malandragem, a umbanda, a feijoada, manifestações que tiveram origens populares, posteriormente transformadas em símbolos nacionais.

Tudo isto acontece num momento de grandes transformações sociais, econômicas e políticas. Esse processo se inicia juntamente com a consolidação do mercado nacional, com a indústria passando a ser uma categoria cada vez mais importante. E mais ainda, é essa também a época em que se desenvolveu a indústria cultural no Brasil, o rádio mantendo sua hegemonia na década de 1920 até a implantação da televisão nos anos 1950.

Uma questão fundamental que provavelmente se colocará com maior intensidade, portanto, é a da existência de dois movimentos contrários que se farão sentir mais marcadamente nesta década: por um lado, à medida que uma ordem burguesa se consolida no Brasil, acentuar-se-á a tentativa de construir uma hegemonia através dos meios de comunicação de massa e do Estado. Por outro lado, se houver uma crescente mobilização da sociedade civil, é possível que as classes subalternas possam se organizar melhor e encontrar mais canais de expressão e formas de reelaborar as mensagens e ideologias recebidas através do Estado e dos meios de comunicação de massa. ${ }^{75}$

\footnotetext{
74 OLIVEN, Ruben George. Op. Cit.. p. 45.

75 OLIVEN, Ruben George. Op. Cit. p. 52.
} 
Em meio a esse clima de dominação hegemônica encontra-se o cururu, uma cultura popular própria das classes subalternas, ainda presente no Brasil, principalmente na região do Médio Tietê no interior dos estados de São Paulo e Mato Grosso, e que procuram encontrar esses canais de expressão criando, assim, uma forma de resistência. 
CAPÍTULO II

Uma viola, uma roda, uma tradição 


\section{Uma viola, uma roda, uma tradição}

Quem já foi ou já ouviu falar em Piracicaba, notou que lá continuam presentes manifestações folclóricas caipiras que se misturam com suas belezas naturais e com o seu patrimônio histórico. Uma cidade privilegiada por manter vivas suas tradições, lendas e costumes na história cultural da cidade.

Entre as culturas e as manifestações folclóricas podem-se destacar a Congada, a Catira, o Cateretê, a Festa do Divino e o Cururu - esse último objeto de estudo deste trabalho -, que obteve ao longo dos anos uma modificação cultural, resultante do seu contato com os centros urbanos e industrializados, com a cultura das cidades e também com as inovações tecnológicas pelas quais o mundo tem passado.

\section{$2.1 \quad$ Origem do cururu}

Motivo de polêmica, a origem do cururu é discutida por folcloristas, estudiosos e cururueiros que apresentam algumas idéias sobre o tema, umas relacionando a origem com fontes mulçumanas, jesuíticas e bandeirantes, outras relacionando com o nome de uma planta ou de um sapo.

Segundo Luyten,

A origem do cururu chegou a ser motivo de polêmica. Embora João Chiarini continue afirmando que "o cururu nos tenha chegado de fontes mulçumanas por intermédio de Portugal", praticamente todos estão unânimes no que se refere à junção de elementos de dança indígena a cantoria e motivos católicos introduzidos pelos jesuítas nos primórdios da nossa colonização. ${ }^{76}$

\footnotetext{
${ }^{76}$ LUYTEN, Joseph M.. Desafio e repentismo do caipira de São Paulo. In: BOSI, Alfredo. Cultura brasileira: temas e situações. p. 94.
} 
Antonio Candido elaborou um cuidadoso estudo dedicado a esse respeito chamado Possíveis raízes indígenas de uma dança popular.

No estudo de Antonio Candido, existe o relato dos viajantes alemães Max Schimidt, no início do século XIX, e Edmund Doppenschimidt, mais recentemente, que encontraram larga prática do cururu entre os índios Guató Kinikinaú.

O autor não duvida de que "trata-se de um traço tomado à cultura cabocla, e integrada em cada tribo de acordo com a sua respectiva organização". 77

Nesse sentido, há observações, feitas por Mario de Andrade:

[...] os processos coreográficos desta dança têm tal e forte sabor ameríndio, pelo que sabemos das danças brasilísticas com a cinematografia atual, que não hesito em afirmar ser o cururu uma dança ameríndia, introduzida pelos jesuítas nas suas festas religiosas, fora (e talvez dentro) do templo. Esse costume e dança permaneceram vivos até agora. ${ }^{78}$

Segundo Castilho,

o cururu é um desafio cantado, da região paulista conhecida como Médio Tietê. É considerado uma das mais importantes formas de manifestação da cultura brasileira. Chegou ao Brasil pelas mãos dos bandeirantes, portanto, com raízes portuguesas. ${ }^{79}$

Outra origem é indicada no site Planeta Cururu, afirmando como um enigma folclórico, o nome cururu surgiu devido aos seguintes motivos:

- A planta, que era cozida junto com o feijão, chamada caruru;

- sapo, que se chama cururu, porque, quando se acasala, pula em uma trajetória redonda.

\footnotetext{
${ }^{77}$ LUYTEN, Joseph M. Op. Cit. p. 94.

${ }^{78}$ CASTILHO, Dinah e CASTILHO, Venceslau. Raízes caipiras de Piracicaba na era da globalização - o cururu, a catira e a moda-de-viola. p. 41.

${ }^{79}$ Ibid.. p. 42.
} 
Apesar de contraditórios, os dois motivos remetem à criação do Cururu, porque nessa época, era costume servir às pessoas um caldo de feijão com caruru, antes de se iniciarem as orações e, como dança de roda, havia uma formação em forma de círculo, onde se localizavam: altar, violeiro e repentista.

No entanto, muitas pessoas que moram na área rural da região do Médio Tietê, assimilaram o nome "Caruru" para designar o canto de repente, de forma que as pessoas mais antigas, que pressupomos que tiveram mais acesso à cultura em termos de originalidade, se referem ao Cururu como "Caruru". ${ }^{80}$

Curiosamente, o sapo cururu não se encontra próximo da região do Médio Tietê paulista, tendo seu habitat natural na Região Nordeste do Brasil.

Por esse motivo, algumas pessoas indicam o caruru como o "Canto de Repente" paulista, para ser fiel às tradições.

\subsubsection{Definições de cururu}

Existem definições diversas do termo cururu, sendo muito difícil afirmar qual delas é a que melhor expressa o seu significado. No entanto, é muito importante discorrer sobre tais definições.

Segundo Castilho, existem duas versões sobre o termo:

Quanto à identificação da palavra cururu, existem polêmicas quanto à origem do termo. Encontramos o mesmo, referindo-se a um tipo de sapo. Em outra versão, a palavra encontra-se atrelada à dança de São Gonçalo. ${ }^{81}$

Nota-se que o nome cururu é ligado à denominação "sapo" em tupi-guarani.

Para Luyten, há também uma ligação com uma dança:

Seria a "dança do sapo" com elementos cristãos. A ligação parece estabelecer-se, pois não há essa dança em povos indígenas que não

\footnotetext{
${ }^{80}$ Disponível em: http://www.unimep.br/fc/cururu/server/oqecuru.htm. Acesso em: 18 maio 2006.

${ }^{81}$ CASTILHO, Dinah e CASTILHO, Venceslau. Op. Cit. p. 43.
} 
sejam da raça tupi. Por outro lado, alguns autores apostam a ligação da palavra "cruz" com o guarani "curuçu", assim como o cururu faz parte integrante, com muita freqüência, da dança de Santa Cruz. ${ }^{82}$

\section{Outra definição freqüentemente citada é a de Mário de Andrade:}

É curiosíssimo notar que até hoje, em certas festividades coreográfico-religiosas conservadas tradicionalmente pelas populações rurais paulistas, a dança de Santa Cruz, a dança de São Gonçalo, as partes mais especialmente religiosas da cerimônia são continuadas por uma dança de roda geral, a que chamam de cururu. Ora, se trata de uma dança impressionantemente assimilável em seus passos e ademanes a certas coreografias ameríndio-brasileiras ainda atuais, reveladas pela cinematografia. Parece pelo que sei que a dança de Santa Cruz vive exclusivamente, ou quase, nos vilejos muito atrasados que jazem nas partes não progredidas dos arredores de São Paulo. Alguns destes povoados (como Carapicuíba, onde mais viva se conserva a dança de Santa Cruz) vêm das primeiras povoações defensivas e de penetração, fundamentadas pelos jesuítas em torno de Piratininga. No cururu religioso dessas danças tradicionais, julgo ver uma tradição jesuítico-ameríndia permanecida por quatro séculos. ${ }^{83}$

Luís da Câmara Cascudo simplifica a questão, referindo "Cururu: dança, canto em desafio, relacionados com as festas religiosas no plano da louvação popular" ${ }^{\prime 84}$.

Luyten cita também Antonio Candido, que esboça a expansão do cururu na cultura caipira:

O cururu deve ter sido incorporado como complemento da dança de Santa Cruz, aqui formada, e em seguida da de São Gonçalo, aqui reformada. De modo mais autônomo, incorporou-se também aos festejos populares de junho, de Pentecostes e do natal, já aí, provavelmente, menos por intervenção jesuítica do que por incorporação espontânea, propiciada pelo seu significado emocional para as populações mamelucas. Esse fato sugere a conjetura de que ocorresse também isolado, desde cedo, como festejo em si. A esse título, é provável que tenha sofrido, posteriormente, influência de danças e cantos de origem portuguesa, como o desafio, a viola e a cana-verde. Teríamos, então, o seguinte quadro: formação, por convergência, de uma dança encerrando de modo bastante completo, às danças de Santa Cruz e São Gonçalo, permeadas de

\footnotetext{
${ }^{82}$ LUYTEN, Joseph Op. Cit... p. 94.

${ }^{83}$ ANDRADE, Mario apud LUYTEN, Joseph M.. Op. Cit. p. 96.

${ }^{84}$ CASCUDO, Luiz Câmara LUYTEN, Joseph M.. Op. Cit.. p. 96.
} 
elementos ameríndios. Manifesta-se independente, como dança religioso-profana, menos importante que as outras modalidades e mais aberta a novas influências portuguesas, incorpora-se, como elemento, a festejos tradicionais portugueses incluídos na cultura popular: santos de junho, Divino, Natal. ${ }^{85}$

Câmara Cascudo, em sua obra Dicionário do Folclore Brasileiro, relata: "[...] vim a saber que se pratica entre Bororós de Mato Grosso a cerimônia ritual e funerária que chamam de bacururu e cururu. Têm radicais comuns. Não é inverossímil que dos Bororós tenha vindo o nome da dança cururu"86.

“A origem do nome Cururu ainda não é certa, mas a hipótese mais defendida é a de que viria dos índios bororos. Isto porque, entre os índios, havia a cerimônia do bacururu, celebrada entre clamores e algazarra". ${ }^{87}$

Segundo depoimento do Sr. Luiz Marques da Silva, no site "Brasil no Ar", representando outros cururueiros que têm o mesmo conhecimento:

\begin{abstract}
A origem não é coisa que se passa afirmar cem por cento, porque se sabe que o cururu veio transmitido de pai para filho, mas existe a informação mais conhecida aqui, e que é de conhecimento de todos os historiadores, daquelas pessoas que estudam mais, que esta região principalmente a ribeirinha como o rio Coxipó, era povoada por índios Bororós. Existe a dança dos bororós, dança típica do bacururu, cuja aldeia atualmente fica na beira do rio São Lourenço. $\mathrm{Na}$ dança do bacururu, os índios dançam em roda, sendo o ritmo diferente do cururu, mas o termo pode ter se originado daí. Naquela época poderia ter tido uma pessoa que ao invés de dizer bacururu teria dito cururu. ${ }^{88}$
\end{abstract}

Em uma separata, intitulada Cururu: resistência e adaptação de uma modalidade musical da cultura tradicional paulista, o autor Alberto Ikeda revê

\footnotetext{
${ }^{85}$ CANDIDO, Antonio apud LUYTEN, Joseph M.. Op. Cit.. p. 96.

${ }^{86}$ CASCUDO, Luiz Câmara apud CASTILHO, Dinah. Op. Cit.. p. 41.

${ }^{87}$ Site:http://www.glogernet.pro.br/glogernet/cultura\&lazer/folclore/danca\%20populares/danca_cururu. Acesso em: 15 maio 2006.

88 Site: http://www.brasilnoar.com.br/MT/est_mt_dan\%E7as_orig_cururu.htm. Acesso em: 15 maio 2006.
} 
algumas definições conceituadas em épocas diferentes. Além da já referida por Câmara Cascudo o autor cita também:

Segundo Araújo: "O cururu é uma dança de fundo religioso, geralmente realizada à noite, na qual são cantados desafios dentro de um certo cânone que se chama "carreira"ou "linha" e que é determinado pelo pedestre"89

Antônio Cândido assevera que "Cururu é dança praticada pelos caboclos de São Paulo, Goiás e Mato Grosso". ${ }^{90}$

Já João Chiarini relata que "Cururu é disputa, combate poético". ${ }^{91}$

Segundo Helio Damante,

$\mathrm{Na}$ verdade trata-se mais de um desafio entre violeiros, de uma forma caipira de repentismo, do que propriamente de uma dança, pelo menos nas variantes que remanescem. Ocorre, porém, contar sempre com platéia atuante, a intervir com seus motes, a incentivar ou vaiar os cantadores, acompanhando-lhes o ritmo. Adquire assim um colorido de espetáculo - e como espetáculo, inclusive com cartazes, é apresentada nos teatros e circos, nas festas cívicas e religiosas. ${ }^{92}$

Dentre as considerações expostas por Ikeda, a mais compatível com o cururu na atualidade, no estado de São Paulo, segundo o autor, é a de Hélio Damante, mas com algumas observações importantes feitas por Ikeda:

Embora o desafio não seja necessariamente "entre violeiros". Os cururueiros hoje em dia dificilmente se acompanham à viola, apenas cantam, ficando a função de acompanhante a cargo de outros violeiros. [...] Bastante oportuna é a observação de que o cururu adquiriu caráter de espetáculo, pois esse é um dos aspectos que prevalece atualmente. ${ }^{93}$

\footnotetext{
89 ARAÚJO apud IKEDA, Alberto T. Cururu: resistência e adaptação de uma modalidade musical da cultura tradicional paulista. p. 48..

${ }_{90}$ CÂNDIDO, Antonio apud IKEDA, Alberto T. Op. Cit. p. 48.

${ }^{91}$ CHIARINI, João. apud IKEDA, Alberto T. Op. Cit. p. 48.

${ }^{92}$ DAMANTE, Helio. apud IKEDA, Alberto T. Op. Cit. p. 48.

${ }^{93}$ IKEDA, Alberto T. Op. Cit.. p. 48.
} 
Pode-se observar que hoje o cururu é uma mistura de todas essas considerações expostas, com algumas modificações que sofreu com o passar do tempo, modificações estas que podem ser internas ou externas, como exposto por Laraia no capítulo anterior, na qual refere que a primeira é resultante da dinâmica do próprio sistema cultural e que a segunda é o resultado do contato de um sistema cultural com outro.

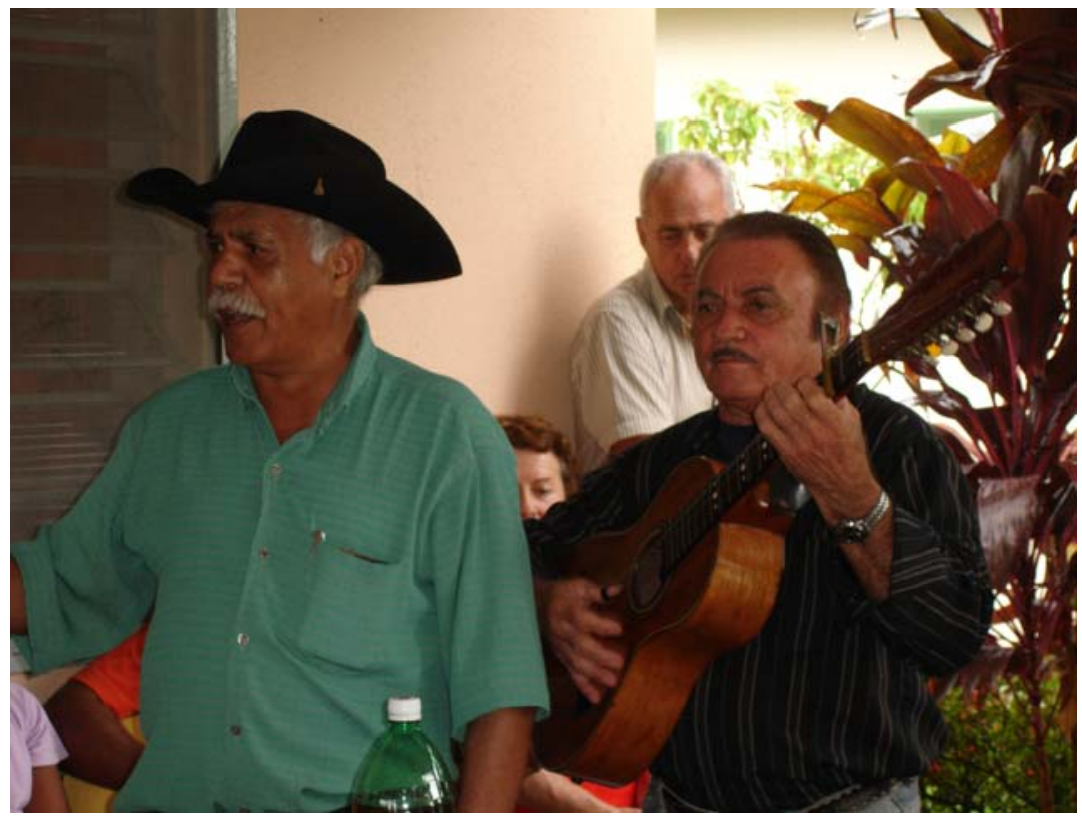

Moacir Siqueira, cururueiro, e Milo Violeiro

\subsubsection{Repente e desafio}

Segundo Luyten, "apesar de ser inicialmente dançado, o Cururu é, sobretudo, um Canto de Repente, de modo que as letras, a melodia e a música são feitas com total improviso". 94

Este improviso é também muito usado no desafio, que é uma das características mais marcantes do cururu, no qual cada cantador busca dar continuidade à carreira (rima) iniciada pelo cantador.

\footnotetext{
${ }^{94}$ LUYTEN, Joseph M. Op. Cit. p. 77.
} 
Bastide, que dedicou um capítulo ao desafio em Psicanálise do cafuné e estudos de sociologia estética brasileira, cujas considerações são válidas para o cururu, destaca que, "no caso do desafio brasileiro, a competição não é de grupos, mas de indivíduos". ${ }^{95}$

"No caso do cururu, ele cumpre uma função de confirmação de expectativas grupais, englobadas no universo de uma cultura"96.

Luís da Câmara Cascudo registrou como desafio:

"Disputa poética, cantada, parte de improviso e parte decorada, entre os cantadores". 97

Quanto ao repentismo, entende-se "a própria improvisação poética no momento em que esta é apresentada." ${ }^{98}$

Outra consideração importante feita por Ikeda, é a de que

os cururueiros ao se referirem ao desafio, estavam na verdade tratando da cana-verde (uma dança de roda) e não do cururu. Segundo o autor, quando os cururueiros eram solicitados a fazer demonstração de desafio cantavam a cana-verde. Para entender melhor Silvio Paes de Sorocaba explica que "na cana-verde um canta uma quadrinha e outro responde", e no cururu "um vai cantando inteiro quantos versos quisé e outro vai escutando, depois outro entra pra respondê". ${ }^{99}$

Assim, conforme Ikeda, os cantadores entendem o cururu como uma modalidade de cantoria de improviso, que pode ou não ter desafio.

Chiarini lembra enfaticamente que "no cururu não há convencionalismos: tudo é improvisado, é criação de momento, se referindo principalmente à estrutura dos

\footnotetext{
${ }^{95}$ BASTIDE, Roger apud ESCALANTE, Eduardo A. A música no cururu do MédioTietê paulista. p. 93.

${ }^{96}$ ESCALANTE, Eduardo A. Op. Cit. p. 94.

${ }^{97}$ CASCUDO, Luiz Câmara LUYTEN, Joseph M. Op. Cit. p. 77.

98 Ibid. p. 77.

${ }^{99}$ IKEDA, Alberto T. Op. Cit..p. 51.
} 
versos e as músicas próprias de cada um, tudo é improviso cheio de lembranças mnemotécnicas, de sentimentos religiosos." 100

Dessa maneira, é devido ao improviso que o instinto dos cantadores vai se aguçando com o tempo, a prática e a necessidade de adaptação, a perspicácia dos adversários.

É a qualidade do improviso que faz o cantador chegar a "canturião".

Nas entrevistas realizadas, o cururueiro Moacir Siqueira explicou a diferença entre repente e desafio. No repente, o cantador tem de improvisar na hora, pode ser olhando para as pessoas presentes e cantando a respeito delas ou louvando um santo; já o desafio é entre dois cantadores, quando um cantador canta um verso e em seguida o segundo cantador responde com outro verso.

\subsubsection{Carreiras ou rimas}

Outro elemento importante no cururu são as carreiras ou rimas.

Sobre essa questão é importante destacar o ponto de vista de Araújo, considerando que "carreira é sinônimo de linha". ${ }^{101}$

Elas são chamadas de carreiras, linhas ou alinhação, e podem ser emparelhadas ou alternadas.

Nas carreiras, é imprescindível que se faça inicialmente uma louvação, sendo esta dirigida aos santos ou ao povo; logo depois, se o cantador que iniciar o cururu escolher cantar na carreira do "Ão", todos os outros cantadores farão o mesmo, até que o último cururueiro dessa rodada conclua a cantoria na mesma carreira.

\footnotetext{
${ }^{100}$ CHIARINI, João apud ESCALANTE, Eduardo A. Op. Cit. p. 95

${ }^{101}$ ARAÚJO, Alceu Maynard apud CASTILHO, Dinah e CASTILHO, Wenceslau. Op. Cit. p. 118.
} 
É muito interessante observar, neste momento, que "desafio" distingue-se de "verso-batido".

Desse modo, destacam-se as explicações de Araújo, tendo em vista que o autor explica que,

depois que louva o santo ou povo, então é permitido cantar o desafio que não é "verso-batido" e sim "verso-encontrado". "Verso-batido é aquele que um cantador canta e outro responde a seguir, como se faz na 'cana-verde'. Vai rebatendo o que fala. Ao passo que no cururu é diferente, podem ficar cantando até meia-hora, somente depois é que o outro responde, na mesma carreira, quando o desafiante acabou de cantar [...]"102

Segundo Escalante, as carreiras podem ser introduzidas pelos pedestres, sendo que algumas são consideradas fáceis e outras, difíceis.

Carreiras são as rimas, as vezes introduzidas pelo 'pedestre', as quais recebem um nome, oriundo de uma palavra, geralmente de cunho religioso, que lhes dá origem.

Assim sendo haverá carreiras fáceis, e outras difíceis. Algumas quase impossíveis.

Diz João Pontes que, ao todo, há cento e vinte e três carreiras. ${ }^{103}$

“As rimas mais freqüentes utilizadas costumam ser a de 'São João', do 'Sagrado' e a do 'A'". 104

Nesse aspecto, Castilho apresenta como exemplo as linhas feitas pelo cururueiro Antonio Machado, conhecido como o "Rouxinol Capivariano". Até o meio da estrofe, o cururueiro, em disputa com o adversário, utiliza uma rima simples, sendo perceptível que a segunda linha rima com a quarta linha. A partir de então, o canturião prima por rimas dobradas ou ricas, quando a quinta linha rima com a sexta

\footnotetext{
102 ARAÚJO, Alceu Maynard apud CASTILHO, Dinah e CASTILHO, Wenceslau. Op. Cit. p. 118. ${ }^{103}$ ESCALANTE, Eduardo A. Op. Cit. p. 59.

${ }^{104}$ CARRADORE, Hugo Pedro apud CASTILHO, Dinah e CASTILHO, Wenceslau Op. Cit. p. 47.
} 
linha. Essas linhas foram publicadas no jornal A Tribuna Piracicabana, no espaço semanal intitulado Universo Caipira:

\author{
Muitos me chamam de caipira. \\ Eu sou mesmo um caipirão, \\ sou nascido lá na roça, \\ num ranchinho beira chão. \\ Naquela casinha modesta, \\ onde me lembro das festas \\ Da paz, do amor e da união. ${ }^{105}$
}

As rimas que são consideradas mais difíceis pelos cantadores são as de 'São Vicente' (ente), 'Presumido (ido)', do 'Sol (ol)', 'Santa Teresa (esa)'.

Outras carreiras são consideradas fáceis, como a de "São João" (ão), do "A" (a), e do "sagrado" (ado). Geralmente, o oponente fica na obrigação de responder na mesma carreira.

Luyten apresenta um desafio entre Antônio Vilanova e Zico Mineiro:

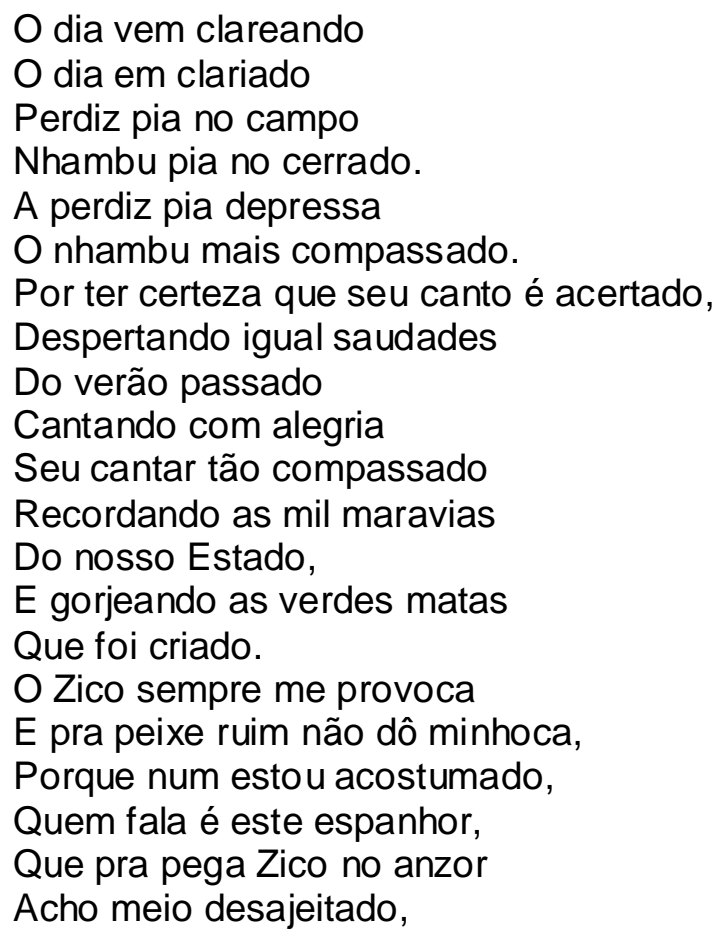

${ }^{105}$ CARRADORE, Hugo Pedro apud CASTILHO, Dinah e CASTILHO, Wenceslau Op. Cit. p. 47. 
Porque eu falo pra esta gente,

Que Zico não tem dente,

É um peixe desdentado.

Ao que Zico Mineiro responde:

Meu amigo Vilanova veja

Como você está enganado.

Eu como esta minhoca

E fico sustentado,

Dispois que você pega eu

Que você tive fisgado,

Eu puxo seu bote,

Você morre afogado,

Porque sou um peixe de muita força

Dum tamanho dobrado. ${ }^{106}$

\subsubsection{Os versos}

No cururu há dois tipos de versos, quase sempre inteiramente improvisados: os "trovados", que não são desafio e sim apenas improvisações, e os "encontrados", que constituem a peleja propriamente dita.

Segundo Carradore, "os 'trovados' não são dirigidos ao canturião adversário, os 'encontrados' ou 'bate de pau trocado' são respostas dadas por um cantador aos versos, que seu adversário Ihe dirigiu na volta anterior". ${ }^{107}$

Os versos podem considerados de caráter religioso ou profano.

"Religiosos são os versos fundamentados na Bíblia ou na vida dos santos. Profanos são aqueles construídos sem preocupação de ter molde os textos sacros; são de escárnio, satíricos, anedóticos, sociais e, muitas vezes, líricos". ${ }^{108}$

Luyten apresenta um exemplo de versos "trovados", no caso, a seqüência a uma festa de São Gonçalo:

\footnotetext{
106 LUYTEN, Joseph M.. Op. Cit. p. 98 e 99.

107 CARRADORE, Hugo Pedro. Op. Cit. p. 59.

108 Ibid. p. 59.
} 
Pro dono dessa promessa

Agora vou cantar

São Gonçalo do céu

Nos veio visitar.

O dono dessa promessa

Já pode ir-se alegrando,

São Gonçalo lá no céu

Já está-lhe esperando. ${ }^{109}$

\subsubsection{Temática}

Antigamente nas disputas cururueiras, o tema central que dominava era o religioso. De acordo com os cantadores mais experientes, para ser canturião, era necessário cantar conhecer os "livros de religião" e a história dos santos.

Existe a louvação, que é quase uma oração, uma profissão de fé das verdades bíblicas, indiscutíveis para os curureiros. João Pontes, nestes versos contidos no livro de Carradore, é taxativo:

\footnotetext{
Eu vô faze uma louvação na carrera do presumido, sobre a criação du mundo que Deus tinha construído. Quando Deus feiz o mundo Bem certinho e repartido. Cada coisa em seu lugá, Tudo certo e dividido.

Do lado do oriente, Esse lugá foi escoido, Deus crio o jardim terrestre, Era um bosque bem florido.

Ali Deus ponho Adão e Eva Que era muié e marido, E ali eles cometero um erro, Onde os dois fico perdido.

Eva comeu o fruto
}

${ }^{109}$ LUYTEN, Joseph M.. Op. Cit.. p. 98. 
Que Deus tinha pruibido,

A metade ela comeu,

A metade não foi comido.

Essa metade guardo pra Adão,

Que era de fato seu marido,

Quando Deus chego no jardim

Sua voiz foi ouvido:

"Adão onde ce ta?"

ele respondeu escondido,

pruque os dois tava nu,

e viro que tava despido.

Então Deus respondeu

Com ar muito aburrecido:

"vai vê oceis comeu o fruto

que eu tinha pruibido".

Adão foi quem respondeu

Muito desinchavido:

Foi a serpente que mando

Pur ela fumo inludido.

E nois vimos que tava nu

E fiquemo surprendido,

E com foia de figuera

Nois fizemo

0 vestido. ${ }^{110}$

Segundo Carradore, esses versos, além de uma mensagem de temor e obediência a Deus, são também uma profissão de fé.

De acordo com o autor, a poesia do cururu é a própria aproximação à terra; o rimanceiro nem sempre se apóia sobre misticismo ou sátiras; também há um caráter profundamente social considerando a realidade do meio em que vive. A vida na sua terra, as roças, a chuva, a estiagem, ele canta. Portanto, não é algo marginal, indiferente; o cantador sente-se útil à pátria com sua linguagem poética. Esses versos cantados por Vilanova expressam bem essa vinculação do homem à terra:

Quando amanhece um dia são diferente os pensa, trabaiando na roça

${ }^{110}$ CARRADORE, Hugo Pedro. Op. Cit..pp. 61 e 62. 
põe os burro na carroça,

lutando pra cá e pra lá.

Por de letra sê um recruta,

Curtivando a terra bruta

Sem sabe se ela vai dá,

No grande afã

Esperando pelo amanhã,

Que Deus não pode farta

Eu digo que Deus é brasileiro

$E$ de nóis sempre se lembra.

Conforme Gonsarve Dia escreveu

É tão fáci de observa,

Onde ele passa conta:

Minha terra tem parmera

Onde canta o sabiá.

Quem vê as nossa mata,

Coisa linda mais num há,

Num brasio imenso

Que nunca pode se acaba.

Do jeito qu'ele escreveu,

Do modo de interpreta

Onde canta o mérro e o sabiá,

Onde canta todas as ave,

Onde só tem que cantá

A paixão do brasileiro,

Que tudo tem se apaxoná,

Neste terra que nascemo

E que devemo amá,

Sô fio de estrangero

Mais digo que Deus é brasilero,

Disso nóis tem sempre que alembrá. ${ }^{111}$

No Lirismo, além de dedicado a Deus e a "Terra", a mulher também tem um papel fundamental, despertando o lado poético que existe no troveiro. Constante nos versos, o tema amor é praticado em altas doses; contudo, é uma prática incrível, pois, segundo Carradore, "esses homens são de uma timidez muito grande e vêem na mulher um fruto proibido, nutrindo por ela um sentimento quase nunca anunciado em público". 112

O mais ferino dos canturiões, Onofre Jordão, assim citado por Carradore, mostra quanto lirismo e respeito há nesses versos:

${ }_{112}^{111}$ CARRADORE, Hugo Pedro apud CASTILHO, Dinah e CASTILHO, Wenceslau Op. Cit. p. 63 e 64. 112 Ibid. p. 64. 
Falo bonito pro povo entende, comparo o home co cravo, quando não co a frô do ipê, comparo as muié co a rosa, que tudo mundo gosta de vê. ${ }^{113}$

\title{
Carradore ainda constata que
}

\begin{abstract}
a história do Brasil, História Geral e Geografia e a Astronomia são temas de cantorias. Por esse motivo, os cantadores procuram "estudar" e informarem-se sobre esses assuntos no sentido de evitarem serem pegos em falhas durante a peleja.

Também fatos do cotidiano - são lembrados no cururu: trabalho, dificuldades financeiras, divertimentos, acontecimentos anedóticos, casamentos, batizados e até mesmo a morte serve de temática cururueira. ${ }^{114}$
\end{abstract}

Interessante que até nos momentos políticos os cantadores participam. Nas lutas eleiçoeiras eles tomam partido, ficam do lado de um ou outro político. Nos seus versos há um pouco de tudo, elogiam, enaltecem, criticam, caçoam ou castigam.

Os especialistas em propaganda política não dispensam o cururu no momento em que os comícios estão acontecendo. A propaganda justifica plenamente o "Cururu eleiçoeiro", realizado durante as campanhas (comícios e rádio) políticas na Zona Cururueira. Ali eles são responsáveis em ressaltar as qualidades dos candidatos, em versos trovados, e, para tal, são muito bem pagos.

Entre estes, foram registrados os de Lazinho Marques, na campanha do falecido Emílio Sebe (Anuar), vereador em Piracicaba em várias legislaturas:

Na eleição de 59, não esqueço do passado, teve muitos vereadô que foram bem apoiado mais nosso amigo Anuar que foi um dos mais votado.

\footnotetext{
${ }^{113}$ CARRADORE, Hugo Pedro apud CASTILHO, Dinah e CASTILHO, Wenceslau Op. Cit. p. 64 ${ }^{114}$ Ibid..p. 64
} 
Lazinho arremata:

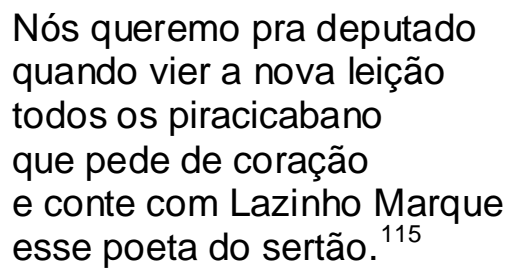

Mesmo nos combates mais violentos, o cururueiro fica muito atento ao seu vocabulário. Antigamente, jamais foram ouvidas palavras obscenas no cururu.

Muitas vezes, no auge do verso trocado, os cururueiros lançam mão de todos os recursos, citando até situações particulares das famílias de seus adversários, motivo leva curureiros e compadres a se tornarem inimigos. Esses cururus chegaram muitas vezes a terminar em luta corporal. Os versos abaixo fornecem um bom exemplo:

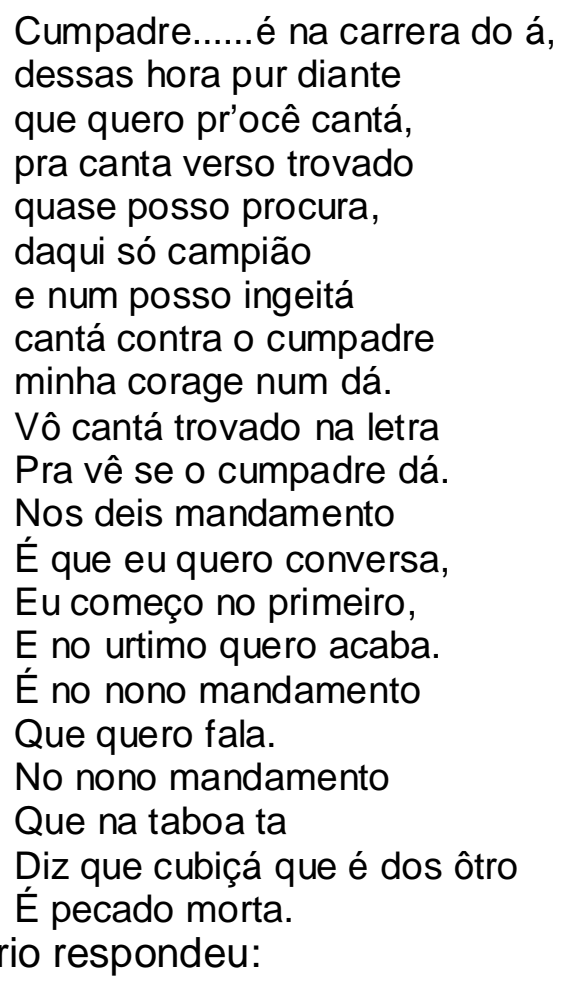

${ }^{115}$ CARRADORE, Hugo Pedro. Op. Cit..p. 65. 
oh! Meu amigo .......

essa vai daqui pra lá, ocê canto um verso que num devia cantá, pruque num sei lê e escreve, ocê qué me defamá.

O nosso mundo ta no fim, Agente pode desconfia. Meu pai tem um ditado, Sempre vi mamãe fala Quando cumpadre começa num cumbiná, Que nem o cumpadre, Ocê devia imagina, Dois cumpadre cantá contra Imagine de nois dois o que será, Quando nóis morre, Nois dois vai pagá, Eu vô se tição de fogo, E ocê será boitatá.

Oh! Cumpadre ....

Ocê devia era nota que nos deiz mandamento, Que eu vi ocê puxa, O padre puxa na igreja Pra ensina criança reza. Se eu num subé os deis mandamento, Meu cumpadre o que de mim será? Ocê diz que o nono mandamento, Que na Bíblia marcado ta, Que cubiça o que é dos ôtro, É pecado morta. Paper aceita tudo, Eu não posso aceita, Cubiça num é pecado, Ocê pode acredita, Ocê quer me explica, Quem é que foi de sua muié Antes de ocê casa? ${ }^{116}$

Nas entrevistas feitas para este estudo, os cururueiros se queixam da falta de respeito de alguns cantadores, que estão inserindo palavras obscenas no desafio de cururu.

Abel Bueno, um dos mais conceituados e tradicionais cururueiros de Piracicaba, revela em uma entrevista que:

${ }^{116}$ CARRADORE, Hugo Pedro. Op. Cit. p. 66 e 67. 
"Hoje está difícil achar cururueiro que cante, contando a história de Jesus, por exemplo; hoje o pessoal só qué falá besteira, é um xingando o outro, sem respeito, coisa que não existia antigamente, não se admitia isso no cururu".

Observando as apresentações hoje em dia em praças e bares de Piracicaba, e no programa de rádio da Educadora, que tem platéia, nota-se que alguns cururueiros, antes de começar a cantar, anotam em um pedacinho de papel ou em suas próprias mãos nomes de pessoas que estão presentes no local, para que na hora de suas apresentações possam fazer versos de improviso com os nomes anotados ou com características peculiares das pessoas, como, por exemplo, uma barriga grande, pouco cabelo, um "bigodão", etc.

Um exemplo é o improviso de Moacir Siqueira em uma apresentação:

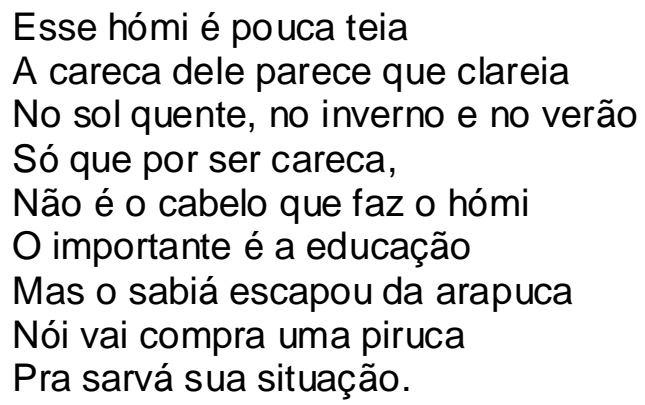

Outra modificação reparada na temática, o que parece ser uma grande influência das mídias e da indústria cultural, é a inserção de letras de funk nos versos de cururu, sendo denominado cururu moderno pelo violeiro Milo e por Moacir Siqueira.

Moacir Siqueira, cantador de cururu há quarenta e dois anos, conta:

"Eu fui cantá na festa de Tupi, pra umas vinte e cinco mil pessoas, às dez e meia o locutor anunciô eu. Eu cantei, veja bem, lembro como se fosse agora: 
Hoje, juventude que me ouve

O Brasil de hoje tá entregue na sua mão

Primeiro, segundo, terceiro e quarto ano o diproma vem na mão

O rio tem que te água de sobra,

todas água dão vorta seu diproma não.

Quinta, sexta, sétima e oitava série segue outra direção

Com muita dificuldade eu construí toda cidade

Formá na faculdade uma boa profissão.

Cadê os aprausos desse povo? Ninguém apraudiu, mas continuei:

Vamo todo mundo apraudí, em nome do rei Davi

Hoje aqui em Tupi um viva a São João.

Era o padroeiro, festa de São João... pouco aprauso. Veja bem, a rádio a TV nem interessô. Aí eu mudei, foi a hora que eu parti pro funk, eu falei:

\footnotetext{
Vem de cá minha popozuda, quero ver seu popozão

Martela, martela, martela o martelão

Fica entre nói, tapinha não dói

Não vô metê minha mão

E na dança da motinha popozuda perde a linha

Eu vô pegá ocê na estação.
}

Aí arrebentô a boca do balão, chego junto todo mundo comigo, até político subiu no palco, deputado estadual, federal, prefeito, subiram no palco pra ficá comigo. Aí aproveitei:

\footnotetext{
A preparada no salão

Dando rebolada de cima até no chão

Qué dança, qué dança o tigrão vai te ensina

Eu passei cerol na mão

Beijo doce como açúcar,

Vem minha pitchuca

Aqui tá o teu tigrão.

A preparada no salão

Na motinha do tigrão

Rebolando o corpinho de violão
} 
Eu num quero que ninguém morra

E as cachorra?

Óia aqui mai um cachorrão

Quero vê se eu consigo

Sê um cachorro amigo

Do que um amigo cão

Tem muita mulher mudando de opinião

Fazendo cirurgia com bom cirurgião

Eu não sô ingnorante

Tão fazendo imprante a famosa imprantação

Eu falo pelo microfone

De tanto silicone

A laranjinha virô mamão

Vô falá pro cê, pelo amor de Deus, todo mundo apraudiu".

Para alguns cururueiros essas modificações na temática têm feito com que o cururu perca a sua originalidade, sua essência, seu respeito; para outros, a fim de que o cururu acompanhe o que está acontecendo e não caia no esquecimento, essas modificações têm de ser feitas, caso contrário ele perderá espaço nos eventos e também na mídia.

Como referido no primeiro capítulo, ultimamente o que se vê são produtos de baixa qualidade. Para ser consumido pela massa, é preciso ser nivelado por baixo, ou seja, cultura de fácil entendimento, o que é traduzido pelos mais intelectuais por baixa qualidade.

Um ponto de vista sobre esta questão, também exposto no capítulo I, é a opinião de Strinati, a qual defende que a arte não pode ser produzida por meio de formas de manufatura rotineira, seriadas, especializadas e fragmentadas, como os produtos da cultura de massa, padronizados e repetitivos. A sua criatividade, sua experimentação, sua complexidade estética e seu propósito intelectual não podem ser obtidos por técnicas que produzem a cultura de massa. O artista tem de 
trabalhar sem as restrições do mercado, das técnicas padronizadas de composição e das fórmulas testadas e aprovadas.

\subsubsection{O cururu como dança}

Como todas as modalidades paulistas que incluem desafio e repentismo, o cururu tem por tradição ser dançado.

Segundo Luyten, nos últimos anos, isso já não acontece mais no estado de São Paulo. Hoje é apenas cantado, muitas vezes em palco, com um altar improvisado. Muitos autores fazem distinção no sentido de o "cururu rural" ser dançado diante de um altar e o "cururu urbano" apenas cantado em palco ou reunião pública.

Escalante ao referir-se sobre o cururu como dança, aborda a visão de Cornélio Pires e João Chiarini:

Cornélio Pires diz ser o cururu "uma dança em que tomam parte os poetas sertanejos, formando roda e cantando, cada um por sua vez, atirando os seus desafios mútuos. [...] É uma dança mista do africano e do bugre".

João Chiarini, por sua vez é bastante explícito ao citar Mario de Andrade, que o considerava uma "dança de roda geral: é preciso que se diga que foi apenas uma roda", e que como tal seja considerado. ${ }^{117}$

Segundo Carradore, "o cururu é um produto de uma miscigenação cultural". Dançando e cantando, com uma coreografia própria que, a despeito da dinâmica do folclore, conserva a dança, no movimento dos pés e no volteio de alguns cantadores a marca das raízes $[\ldots]^{\prime 118}$

${ }^{117}$ ESCALANTE, Eduardo A. Op. Cit. p. 49.

${ }^{118}$ CARRADORE, Hugo Pedro apud CASTILHO, Dinah e CASTILHO, Wenceslau Op. Cit. p. 48 e 49. 
"Essa dança é o nome paulista da dança de São Gonçalo. Seus movimentos recordam o suplício de São Gonçalo" ${ }^{119}$, afirmou o cururueiro piracicabano José da Silva, na obra de Carradore.

Percebe-se que o cururu no passado era dançado e cantado, mas hoje só é cantado.

A dança foi deixada de lado quando o cururu migrou para os centros urbanos, passando a ser apresentado mais em palcos do que em altares, como era no campo.

Essa frase confirma o que Antonio Cândido, citado no primeiro capítulo, expôs sobre a desagregação da cultura rústica do caipira que acontece no contato com as cidades, ou seja, com os centros urbanos e industrializados.

As reminiscências da dança, hoje, encontram-se restritas aos movimentos dos pés de alguns cantadores.

"O negro Antônio Cândido, com a carapinha pintada de branco, o rei de todos os cantadores, recebeu o apelido de 'Parafuso', como foi conhecido, por causa dos seus volteios e rodopios durante suas apresentações."120

\subsection{7 "Rural" e "urbano"}

O cururu irradiou-se da zona rural para os centros urbanos, através da difusão das emissoras de rádio dos municípios cururueiros, cujo centro principal é Piracicaba, considerada até hoje a "capital do cururu".

Carradore discorre sobre o cururu na zona rural e de sua autenticidade no início do século, quando era realizado diante do altar.

\footnotetext{
${ }^{119}$ CARRADORE, Hugo Pedro apud CASTILHO, Dinah e CASTILHO, Wenceslau Op. Cit. p.. 49. ${ }^{120}$ Ibid.p. 49
} 
O cururu na Zona Rural é realizado em frente ao altar, à Bandeira do Divino, nos pousos do Divino, nas quermesses das capelas, após as rezas dos "Santos de Junho". Ele guarda, ainda, o sabor de autenticidade das grandes festanças do início do século. ${ }^{121}$

Já Araújo, no Documentário Folclórico Paulista, propõe uma dicotomia para o cururu: em urbano e rural, da qual Carradore discorda.

Dissertando a respeito do cururu rural, Araújo afirma que o mesmo aproxima-se mais do cururu original. No cururu rural há a presença da dança. Entretanto, não observamos este fato no cururu urbano.

Sobre a questão da contribuição monetária, Araújo busca ressaltar que, no "cururu rural, o cururueiro canta por religião, enquanto no cururu urbano já se visualiza uma comercialização." 122

Em relação aos temas, Araújo explica que "há uma diferenciação no que concerne aos temas. No cururu urbano denota-se uma preocupação maior em ressaltar os problemas sociais e políticos, enquanto a religião é mais cantada no cururu rural." ${ }^{123}$

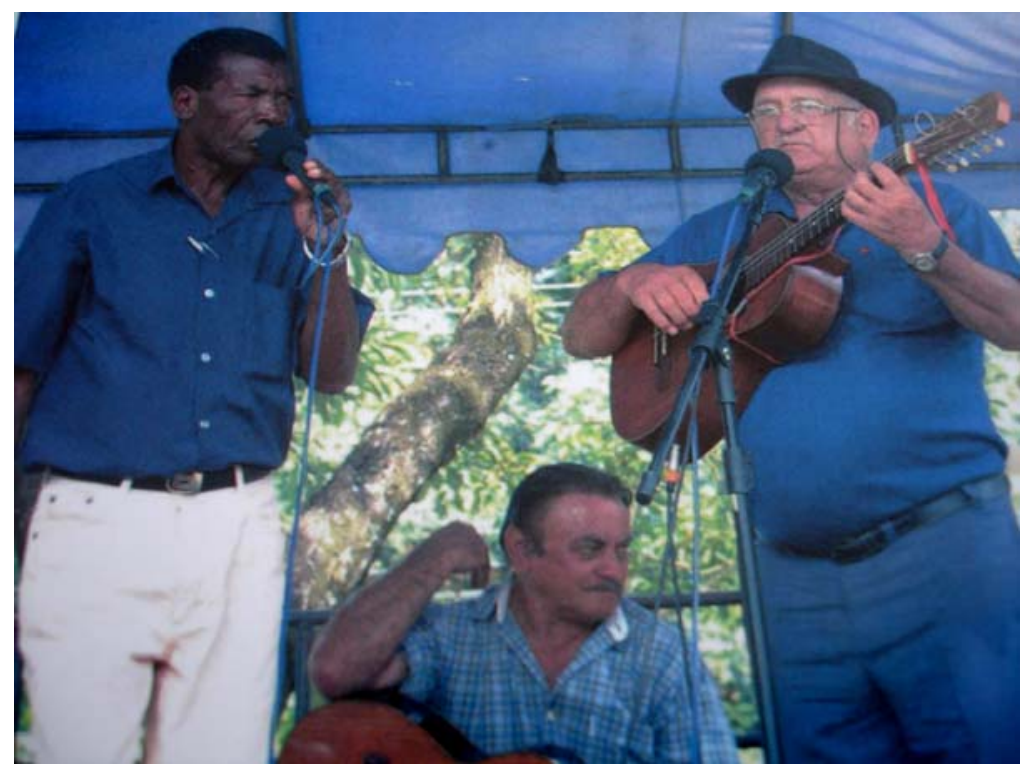

Apresentação de cururu no palco

\footnotetext{
${ }^{121}$ CARRADORE, Hugo Pedro apud CASTILHO, Dinah e CASTILHO, Wenceslau Op. Cit. p. 50. ${ }^{122}$ ARAÚJO, apud CASTILHO, Dinah Op. Cit..p. 42.

${ }^{123}$ Ibid. p. 42.
} 
$\mathrm{Na}$ dissertação de Escalante, podem-se observar algumas diferenças entre o cururu rural e o cururu urbano relacionadas abaixo:

CURURU RURAL:

a) É canto de religiosidade;

b) Se faz a frente do altar;

c) Há sempre versos alusivos à religião, aos temas bíblicos;

d) Há uma coreografia rudimentar, constituída por uma dança (ou andança) de roda;

e) A assistência terá um número reduzido de pessoas;

f) O público estará próximo dos cururueiros;

g) Os cantadores gesticulam pouco;

h) Haverá louvação aos santos.

CURURU URBANO:

a) É profano;

b) Se realiza em palcos;

c) Os temas são preferentemente sociais ou políticos;

d) Não se dança;

e) Haverá uma assistência numerosa;

f) O público estará mais afastado dos cantadores;

g) Os cururueiros gesticulam bastante;

h) Canta-se por dinheiro;

i) Não se faz louvação. ${ }^{124}$

De acordo com as entrevistas realizadas e com as pesquisas exploratórias, pode-se notar que atualmente os cururueiros de Piracicaba não cantam por dinheiro, como referido anteriormente; ao contrário, muita vezes pagam para se apresentar, seja para o violeiro tocar ou para se transportar até o local de apresentação.

Hoje, em Piracicaba, pouco se fala em cururu rural; o que se fala mais é no cururu urbano, mas com algumas diferenças que se destacaram nos últimos anos.

Ao invés dos palcos, usados mais em eventos culturais ou em festas, o cururu está sendo apresentado muito em praças públicas e bares da cidade.

${ }^{124}$ ESCALANTE, Eduardo A. Op. Cit. p. 82 e 83. 


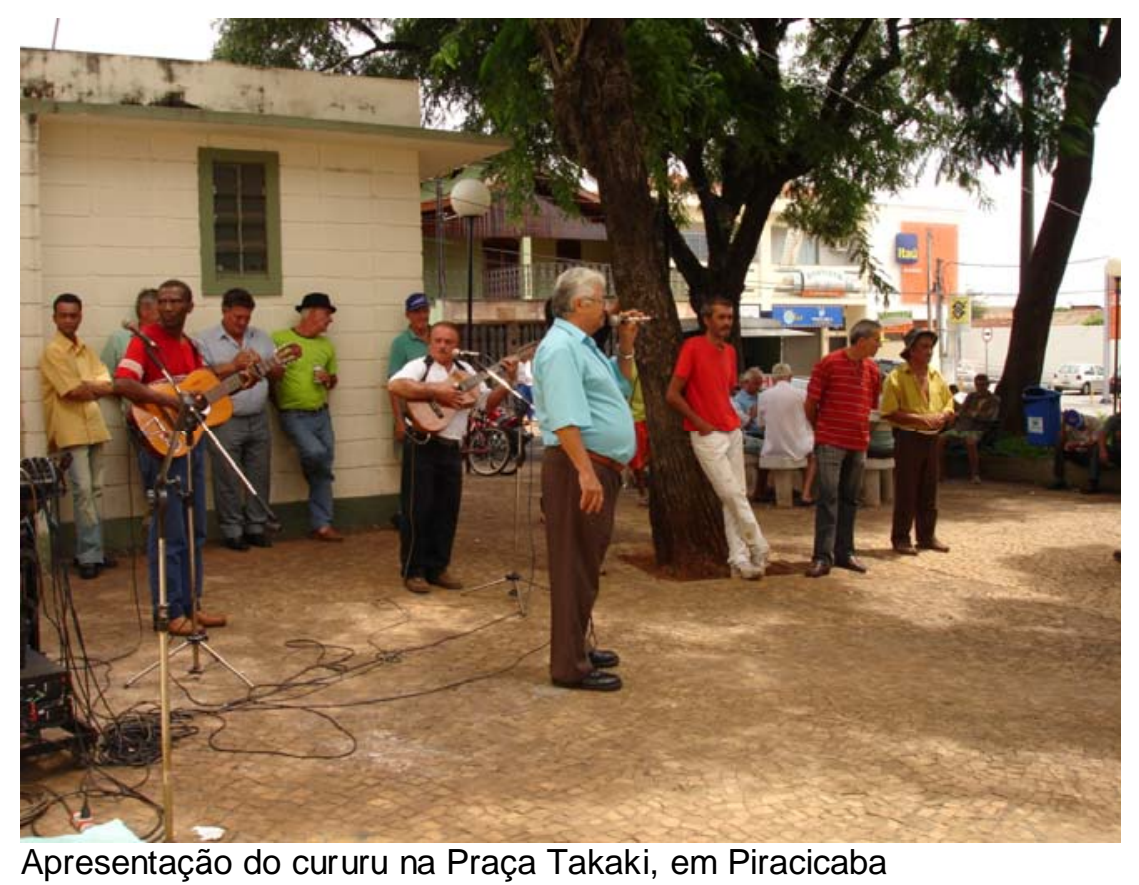

\subsubsection{Curureiros}

O cantor é o repentista, é o improvisador. Não se deve confundi-lo com o violeiro ou com a "segunda". Coutinho Filho menciona que, "tratando dos repentistas do nordeste não faz distinção, que é fundamental quando falamos ou escrevemos em termos de cururu."125

O cantador de cururu, além de ser denominado repentista e improvisador, pode ser chamado também de escritureiro e outros nomes genéricos, como explica Carradore:

Ao cantador de cururu podemos, também, chamá-lo genericamente de trovador, troveiro, rimeiro, rimancista, repentista e especificamente de escritureiro, quando é um mestre em manter a polêmica, cantando não só durante a locução, mas durante toda cantoria, fundamentando-se em textos bíblicos. Se Amâncio de Lara foi o maior no verso "trocado"; João David foi o maior escritureiro.

${ }^{125}$ COUTINHO FILHO, apud CARRADORE, Hugo Pedro. Op. Cit. p. 51. 
Seu lugar foi ocupado por outro veterano - Agostinho Aguiar (já falecido). ${ }^{126}$

A divisão dos cantadores se dá em duas categorias: "Canturiões" e "Canturinos".

Segundo Carradore,

\begin{abstract}
"Canturiões" são os exímios, os mais experimentados, cuja fama corre e todos os respeitam como verdadeiros heróis do cururu, formam, em torno de si, uma atmosfera de verdadeira idolatria, esses são os grandes mestres como: Lazinho Albino, Amâncio de Lara, João David, Zico Moreira, Pedro Chiquito, Sebastião Roque, Villanova, Agostinho de Aguiar, Parafuso, Onofre Jordão, Lazinho Marques, Dito João, Nhô Serra, Moacir Siqueira. ${ }^{127}$
\end{abstract}

Abel Bueno explica que canturiões são os cantadores mais experientes, que cantam há um determinado tempo e que sabem cantar "no livro", fazendo versos bíblicos e que respeitam as regras. Já os canturinos são os cantadores que começaram cantar há pouco tempo, que não possuem muita experiência e que geralmente cantam por pouco tempo.

Repara-se que hoje existem mais "canturinos" do que "canturiões".

Quando foi feita a pergunta na entrevista se a quantidade de cantadores de hoje é a mesma de antigamente, todos responderam que a quantidade é a mesma ou até superior, mas que a qualidade é inferior, pelo fato de os cantadores de hoje terem menos experiência que os cantadores de antigamente.

Em 1947, João Chiarini apontava os seguintes cantadores de destaque de cururu:

${ }^{126}$ CARRADORE, Hugo Pedro. Op. Cit. p. 51 e 52.

${ }^{127}$ Ibid. p. 52. 
Agostinho Aguiar, Antonio Rodrigues de Lara, Antonio Vilanova, Antonio Venâncio Vieira, Augusto Albano de Silva, Benedito Moreira dos Santos (Zico Moreira), Benedito de Oliveira (Dito Mineiro), Brasílio Ferraz de Arruda, Dionísio Cassemiro, Eugênio Pires Correia, Francisco Luiz Martins, Jaciro Correia Filho, João da Costa Carvalho, João Pontes, José de Campos, Pedrilha Pires Correia (a única mulher), Sebastião A. Ferraz, Sebastião Corrêa Gomes de Oliveira, Sebastião Roque Ortiz, Serafim Oliveira Barbosa, Sebastião Soares e Theodoro de Paula. ${ }^{128}$

A pesquisadora Thaís de Almeida Dias lembra os seguintes cantadores de cururu:

"Narciso Correia; Zico Moreira; Parafuso; Nhô Chico; Dito Silva; Luizinho Rosa; Pedro Chiquito; Moacir Siqueira; João David; Horácio Neto; Jonata Neto; Nhô Serra". ${ }^{129}$

Castilho também cita grandes nomes do cururu piracicabano, já falecidos, quais sejam:

Parafuso, Nhô Serra, Zico Moreira, Sebastião Roque, Pedro Chiquito, Lazinho Marques, João Davi, entre tantos outros, que contribuíram na difusão e no reconhecimento desta manifestação folclórica no município de Piracicaba. ${ }^{130}$

Alguns cantadores aparecem em duas ou três relações; pode-se concluir que estes foram ou ainda são considerados ícones desta cultura. De alguns anos pra cá, nota-se que apareceu uma quantidade significativa de cururueiros novos e que não estão presentes nas relações de alguns folcloristas. Nota-se também que não há presença de jovens nas listas mencionadas, e que a maioria dos cantadores tem idade superior a 40 anos.

De acordo com as entrevistas realizadas, percebe-se que hoje não há interesse por pessoas mais novas por esta cultura; um dos motivos desse desinteresse é a influência de outros tipos de músicas inseridas nas mídias.

\footnotetext{
${ }^{128}$ CHIARINI, João apud LUYTEN, Joseph M. Op. Cit.. p. 100.

${ }^{129}$ DIAS, Thais de Almeida apud LUYTEN, Joseph M. Op. Cit. p. 100.

130 CASTILHO, Dinah e CASTILHO, Wenceslau. Op. Cit. p. 48.
} 


\subsubsection{O cururu na mídia}

Em seus tempos de glória, o cururu tinha espaço garantido nas programações das rádios de Piracicaba e da região. Hoje, a situação não é mais a mesma; com o passar do tempo foi se extinguindo este espaço nas emissoras da cidade.

Em Piracicaba, as primeiras apresentações em rádio foram realizadas na Rádio Difusora, lembra Carradore.

O cururu foi levado ao palco, como espetáculo, em 1910, na cidade de Tietê, por Cornélio Pires. Teve seus grandes dias da ribalta, a partir de 1939 até 1953, quando foi derrubado o "Teatro Santo Estevam". As primeiras festanças cururueiras foram efetuadas na "Rádio Difusora de Piracicaba", em 1939. ${ }^{131}$

Ainda abordando do cururu radiofônico, Carradore cita outras rádios e a aparição dos primeiros discos:

Podemos reportar ao ano 1936, quando Cornélio Pires e a "turma" compareciam à "Rádio Educadora Paulista", no Largo da Misericórdia, cujo diretor artístico era o Dr. Lahyr de Castro Coty, para apresentar os primeiros cururus de rádio paulista. Surgiram com a "turma", os primeiros discos "Caipiras", editados pela "Casa Edison do Rio de Janeiro". Manoel Rodrigues Lourenço (Maneco Mandi) guardava em sua discoteca, quatro gravações de cururu da época. Atualmente a "Rádio Metropolitana" desconhece o autêntico folclore musical nacional. ${ }^{132}$

O escritor regionalista e folclorista Cornélio Pires foi quem promoveu as primeiras apresentações de cantos e danças folclóricas paulistas como espetáculo de palco. Ele desencadeou o processo de incorporação da música caipira na

\footnotetext{
${ }^{131}$ CARRADORE, Hugo Pedro. Op. Cit. p. 50.

${ }^{132}$ CARRADORE, Hugo Pedro. Op. Cit p. 51.
} 
indústria do disco e da comunicação. Em 1910, apresentou-se no colégio Mackenzie de São Paulo.

Segundo Macedo Dantas,

em 1929, formou a Turma Caipira Cornélio Pires e praticamente passou a viver como contador de "causos"sobre a vida rural paulista, inclusive gravando e vendendo discos. Explica J. R. Tinhorão que "as primeiras duplas caipiras de São Paulo a gravarem suas composições em discos foram traduzidas do interior, ainda com caráter de amadores, pelo entusiasta da vida rural Cornélio Pires", isso em 1929. ${ }^{133}$

As primeiras gravações de música caipira surgiram graças ao arrojo de Cornélio Pires, em 1929. Mas a visão inteligente da fábrica Victor, reunindo a "Turma Caipira Victor", lançou a partir de outubro daquele mesmo ano os primeiros discos, não apenas no âmbito regional, mas por todo o Brasil.

Segundo Escalante,

A primeira gravação foi o cururu (Victor 33236-A), e a moda-de-viola "Casamento da Onça" (Victor 33236-B), pela dupla Mandi e Sorocabinha. Enfatizamos portanto este fato: o Cururu foi o primeiro registro discográfico da música caipira paulista. ${ }^{134}$

O autor ainda cita os lançamentos:

em 1966 da gravadora Chantecler do LP "Os reis do Cururu" (CH3124); em 1974, a gravadora Marcus Pereira lançaria a coleção "Música Popular do Centro-Oeste/Sudeste, no qual consta o último desafio de parafuso contra Nhô Chico na faixa 5.

A partir de 1939 o cururu foi para o rádio (Rádio Difusora de Piracicaba - PRD-6), e, desta forma, alargou a sua propagação como legítima manifestação de determinados grupos sociais. ${ }^{135}$

\footnotetext{
133 IKEDA, Alberto T. Op. Cit. p. 53.

${ }^{134}$ ESCALANTE, Eduardo A. Op. Cit . p. 128.

135 Ibid. p. 127
} 
Sobre a incorporação da música rural pela indústria fonográfica, Souza Martins assevera que

o cururu, aliás, constituiu uma boa indicação pelas grandes transformações que sofreu quando deixou de ser cururu rural, isto é, dança e canto religiosos, para adaptar-se ao rádio e ao disco. Inicialmente foi apresentado em discos 78 rpm como cântico, sem o desafio secularizado que hoje o caracteriza, surgindo daí uma modalidade de música sertaneja totalmente oposta ao cururu de origem, porque destituída dos seus aspectos formais característicos. $^{136}$

Diante da transformação do cururu em espetáculo artístico, também as rádios, sobretudo do interior, incorporaram em suas programações a presença dos cururueiros, o que ocorreu na década de 1940.

Ikeda explica que "na pesquisa feita em 1983, existiam programas de cururu nas cidades de Sorocaba, Itu, Tatuí e Porto Feliz". ${ }^{137}$

Com o passar dos tempos, o cururu foi perdendo espaço nas rádios de Piracicaba. É este o foco que será abordado no próximo capítulo do presente trabalho.

\subsubsection{Onde existe o cururu}

Os desafios de cururu, apesar de estarem em recessão no estado de São Paulo, resistem à anemia geral causada pelos meios modernos de difusão de cultura mais do que os outros folguedos populares.

A presença do cururu também é notada em outras regiões do país, como Paraná, Mato Grosso e Goiás, segundo Luyten.

Além de possuir, hoje em dia, dois fortes pólos de irradiação no Estado de São Paulo - Sorocaba e Piracicaba -, o cururu continua

\footnotetext{
${ }^{136}$ MARTINS, J.S., apud IKEDA, Alberto T. Op. Cit. p. 54.

137 IKEDA, Alberto T. Op. Cit.. p. 54.
} 
presente em muitas outras localidades interioranas, sobretudo naquelas com menor teor de migração. E mais: o norte do Paraná, Goiás, Mato Grosso do Sul e, principalmente, Mato Grosso têm muitos representantes cantadores de cururu. ${ }^{138}$

Segundo Castilho, "apesar do cururu se manter restrito especialmente às cidades de Sorocaba, Piracicaba e a outras pertencentes a geografia do Médio-Tietê - portanto inserido na cultura paulista - o mesmo também é cantado em Goiás e Mato Grosso."139

Carradore mapeia o espaço do cururu no estado de São Paulo, dizendo que,

O vale do Médio-Tietê, circunscreve a zona do cururu, no Estado de São Paulo. Podemos dizê-lo paulista. Os principais centros em que se pode registrá-lo, como lugar comum da festança, são Piracicaba, Ibitiruna, Salgado, Pirambóia, Botucatu, Laras, Maristela, Laranjal Paulista, Conchas, Pereiras, Bofete, Porangaba, Cesário Lange, Tatuí, Boituva, Alambarí, Itapetininga e Sorocaba.

O cururu, apesar de ser folclore essencialmente paulista, "segundo a rota líquida do Anhembi e, hoje, fora da zona cururueira paulista, encontramo-lo em Mato Grosso, Goiás e Amazonas, onde estiveram os alicerçadores de nossa civilização, que, no tempos das entradas e bandeiras, partiam de São Paulo de Piratininga e, nos seus pousos e ranchos, dançavam o cururu; dessa forma, a dança inicialmente aprendida com os jesuítas, onde foi disseminada por toda a paulistânia - região onde penetrou o bandeirismo."140

Araújo cita, ainda, Americana, Angatuba, Araçoiaba da Serra, Avaré, Barra

Bonita, Capivari, Dois córregos, Guareí, Itatinga, Itapuí, Jaú, Limeira, Macatuba, Mineiros do Tietê, Rio das Pedras, Salto de Itu, Santa Bárbara D`Oeste, São Manuel, Sarapuí, São Pedro e Torrinha.

A melhor referência é a do Mato Grosso, para onde teria sido levado pelos primeiros colonizadores e jesuítas nas suas rotas

\footnotetext{
${ }^{138}$ LUYTEN, Joseph M.. Op. Cit. p. 93.

${ }^{139}$ CASTILHO, Dinah e CASTILHO, Wenceslau. Op. Cit. p. 43.

${ }^{140}$ CARRADORE, Hugo Pedro. Op. Cit. p. 48.
} 
desbravadoras, tendo sido oriundo do Médio Tietê; quem sabe, dos jesuítas que saíram de São Paulo. ${ }^{141}$

É importante não perder de vista que o presente trabalho está focado especificamente no cururu da cidade de Piracicaba.

${ }^{141}$ ESCALANTE, Eduardo A. Op. Cit..p. 87. 
CAPITULO III

VILA NOVA DA CONSTITUIÇÃO 


\section{Vila Nova da Constituição}

Quem chega a Piracicaba vê o bater das horas, no badalar de um sino provinciano. A "Noiva da Colina" ainda se veste de espartilhos, apesar de estar enfeitada de fitas de concreto e brocados de arranha-céus.

Hugo Pedro Carradore

\subsection{Piracicaba}

Localizada a 176 Km da cidade de São Paulo, Piracicaba está situada numa das regiões mais industrializadas e produtivas do Estado.

Piracicaba também é considerada o berço da cultura "caipira" por possuir uma pluralidade de manifestações populares. São inúmeras as tradições que ocorrem às margens daquele que é tido como o principal ícone histórico e referência central da cidade, também tema de belas poesias e canções, o rio Piracicaba, dentre as quais se destacam a Festa do Divino e o Cururu.

As tradições culturais de origens indígenas, africanas e ocidentais, as belezas naturais, a cultura da cana-de-açúcar, o esporte, a educação, e principalmente o rio, que dá origem e nome à cidade, estão historicamente associados à Piracicaba, simbolizando a própria razão de ser dos seus 365.000 habitantes. 


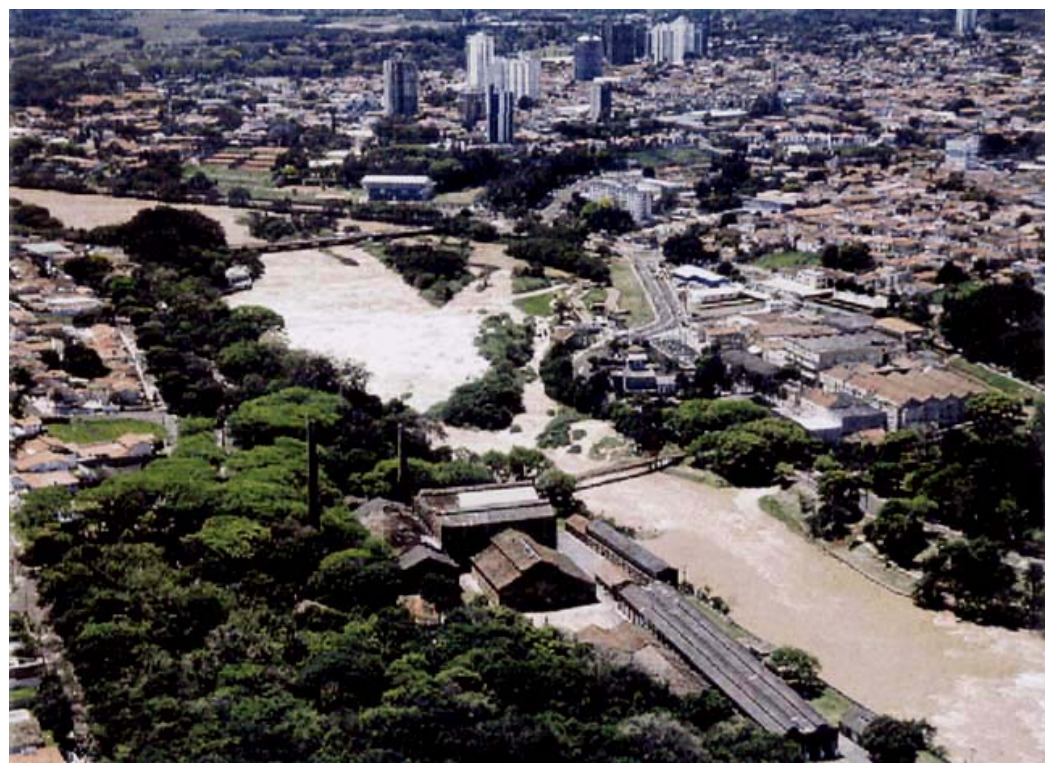

De acordo com uma lenda antiga, conta-se que um dia o rio Piracicaba apaixonou-se por uma bela jovem. Foi um amor tão intenso que, num delírio de suas águas, ele acabou aprisionando-a para sempre no fundo do seu leito. Esta lenda, repetida pelos pescadores através dos anos, ilustra bem o fascínio que o majestoso rio exerce sobre os moradores da cidade e também a todos que o conhecem.

Foi ele quem deu o nome à cidade e determinou seu crescimento servindo como estrada natural de acesso ao sertão. Este rio também foi fundamental para o crescimento da cidade, uma vez que serviu como fonte de renda para várias famílias que em sua margem estavam instaladas e que se mantinham da pesca, do comércio de varas de bambu, de redes, de tarrafas, de minhocas e de peixes, situação esta encontrada também nos dias atuais. Foi, além disso, o principal responsável pelo desenvolvimento das atividades urbanas e industriais da cidade na época.

Segundo Neptune,

a história de Piracicaba se confunde com os noventa quilômetros de extensão do rio homônimo, que a princípio serviu de estrada natural de penetração do sertão. Ele foi o responsável não só por facilitar e estimular o desenvolvimento das atividades urbano-industriais da 
cidade, como também, era fonte de renda para as famílias ribeirinhas que sobreviviam da pesca, do comércio de redes, varas de bambu, tarrafas, minhocas e peixes. Sua presença é dominante, quase imperial, como pano de fundo para todas as fases que se sobrepõem à história da cidade, que começa com o povoamento da região localizada na Depressão Periférica (zona geológica localizada após o Planalto Atlântico e no sentido do Litoral para o Interior de São Paulo) pelos índios dos grupos lingüísticos tupi-guarani. ${ }^{142}$

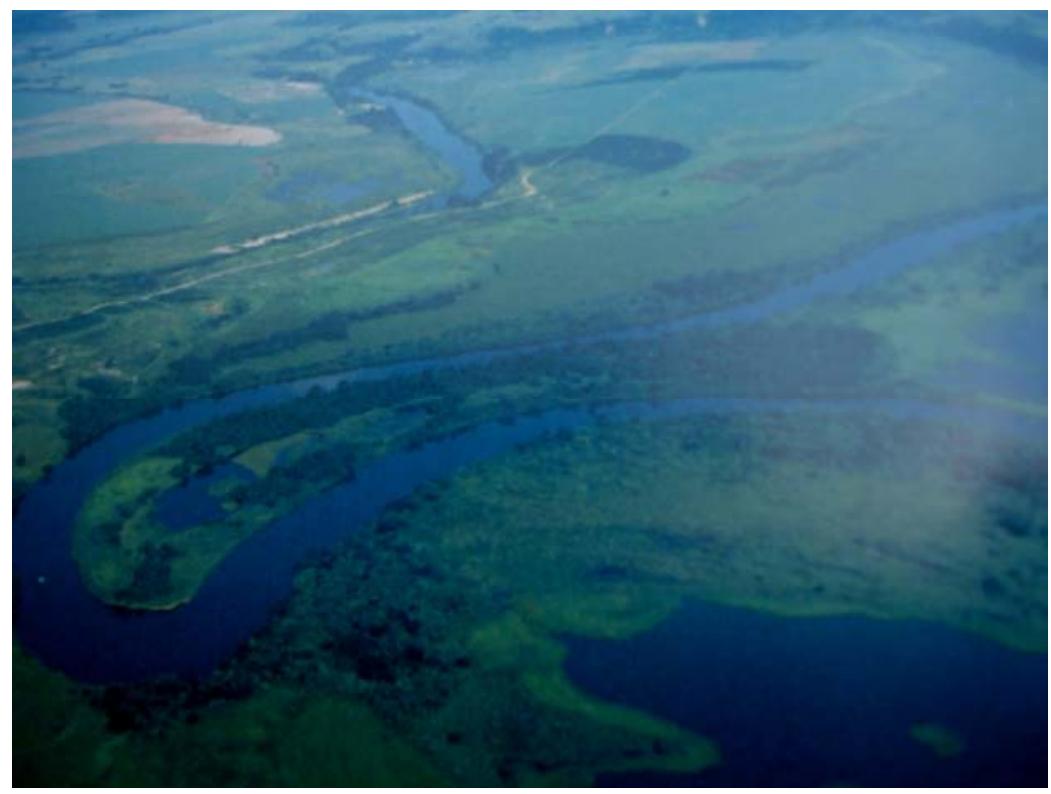

Vista aérea do rio Piracicaba

Há controvérsias sobre a ocupação indígena na região, no que se refere à etnia dos antigos habitantes, os gentios. Mas de acordo com pesquisas realizadas por antropólogos, não restam dúvidas de que essas áreas foram ocupadas por povos pertencentes ao tronco lingüísticos tupi-guarani, que se dedicavam à caça e à pesca. A fartura da pesca no rio Piracicaba e da caça na região teria atraído os primeiros habitantes para o local.

Esses primeiros habitantes, considerados caçadores que vieram guiados pela água, segundo o historiador Leandro Guerrini, seriam possivelmente os Paiaguás,

\footnotetext{
${ }^{142}$ NEPTUNE, Nordahl Christian. Elias dos bonecos, pp. 34 e 35.
} 
caçadores, aventureiros, penetrantes, que seguindo a força atrativa da água, descobriram o sítio, com argúcia congênita, "onde o peixe pára", ou onde o peixe não pode vencer a barreira do salto. O entendimento, então, seria que os peixes chegando, na desova, encontravam o obstáculo do salto, tentando escalar a corredeira, rodopiavam em cardumes nos remansos do rio. ${ }^{143}$

Além de marco histórico e referência central da cidade, o Salto do Piracicaba foi o responsável por facilitar o povoamento pelos índios pescadores, e por favorecer a expansão dos primeiros colonizadores portugueses possuidores de cartas de sesmaria, Instituição do Direito português que consistia na doação gratuita de extensões de terra, que chegaram à região na passagem dos séculos XVII e XVIII, atraídos pela terra de boa qualidade, pesca abundante, madeira e pela caça. Em função dessa localização, os principais rios de São Paulo - o Tietê e o Piracicaba acabaram se tornando os principais eixos de trânsito do colonizador europeu no estado. A navegação fluvial e a estrada de ferro se tornaram os principais auxiliares no desenvolvimento de Piracicaba.

O problema da origem ou etimologia do topônimo "Piracicaba" tem gerado muita discussão entre os filólogos, etnólogos e folcloristas.

No Moderno Dicionário da Língua Português, lê-se: "Pi.ra.ci.ca.ba sf. (tupipirá sykáua) Lugar que por acidente natural no leito dos rios, como queda d’água, não permite a passagem dos peixes, sendo por isso favorável à pesca". ${ }^{144}$

Já no Dicionário Brasileiro da Língua Portuguesa está registrado o verbete: "Pi.ra.ci.ca.ba. s.f. (Bras. São Paulo) Lugar que, tendo cachoeira ou outro qualquer

\footnotetext{
${ }^{143}$ GUERRINI, Leandro. "História de Piracicaba (Noiva da Colina), antes de sua Fundação", In: BARROS, Antônio da Costa. Piracicaba - Noiva da Colina. p. 15.

${ }^{144}$ MICHAELIS. Moderno Dicionário de Língua Portuguesa. p. 37.
} 
acidente natural, não permite a passagem do peixe, sendo, portanto, ótimo pesqueiro". ${ }^{145}$

De acordo com o jornalista Cecílio Elias Neto, "Piracicaba ficou consagrado como lugar onde o peixe pára, lugar onde os peixes se reúnem, ou idéias semelhantes". Em seu Almanaque 2000: Memorial de Piracicaba - Século XX há muitas interpretações sobre a etiologia do nome: A Gazeta de Piracicaba, de 28 de julho de 1888, publicou que o general Couto de Magalhães entendia que Piracicaba significava "chegada dos peixes". Silvio de Aguiar Souza, ilustre professor piracicabano, acompanha Teodoro Sampaio, que na obra O Tupi na geografia nacional, diz ser Piracicaba (pirácycaba) a "colheita ou tomada de peixe". Designa lugar que, por acidente natural do leito do rio, não deixa o peixe passar e favorece a pesca. Um salto ou uma queda d’água é um pirácycaba.

Aguiar Souza se refere também a outra interpretação: "pira (peixe), cica (verbo chegar) e aba (ação), significando, assim, 'chegada dos peixes'”. ${ }^{146}$

O Senador Manoel de Moraes Barros, em trabalho publicado no Almanaque Literário de São Paulo, afirma que "Piracicaba é palavra guarani composta de pira (peixe) e cicaba (fim), significando assim, que aqui se acaba a abundância de peixe". Já Joaquim Silveira Mello, no Jornal de Piracicaba, de 7 de setembro de 1922, faz uma interessante digressão apoiada no dicionarista João Mendes de Almeida. Segundo Mello, Piracicaba é uma palavra cujo significado deriva de composições guaranis e se refere ao salto.

Piracicaba pode derivar de duas composições guaranis com sons semelhantes, mas significados distintos: pira-ci-qua-a (significando a chegada dos peixes, passagem dos peixes), portanto, em relação ao

\footnotetext{
${ }^{145}$ FERREIRA, Aurélio Buarque de Holanda. Dicionário Brasileiro da Língua Portuguesa. p. 1091.

${ }^{146}$ SOUZA, Aguiar apud ELIAS NETO, Cecílio. Almanaque 2000: Memorial de Piracicaba - Século XX. p. 19.
} 
rio, e piha-ci-quab-o (golpe, degrau, alusivo às águas que caem de degrau em degrau), referindo-se ao salto. ${ }^{147}$

Palavra abalizada e de respeito, ao mesmo tempo, é a do botânico Carlos Von Martius, que no Glossaria Linguarum Brasiliensium cita diversas pessoas que atribuem significados diferentes ao nome "Piracicaba".

[...] interpreta o nome como sendo "o lugar onde se ajunta o peixe". Paulo Airosa, pesquisador da Universidade de São Paulo (USP), citado por Hélio Morato Krahenbuhl, autor do Almanaque de Piracicaba de 1955, é de opinião de que "Piracicaba é o lugar onde se apanha o peixe em quantidade, o lugar que retém os peixes". E o mesmo Krahenbuhl - para coletar as mais diversas interpretações faz remissão também ao diário do navegador Teotonio José Zuzarte, de 1769, em que este relata um encontro com o Povoador Antônio Corrêa Barbosa na "Barrado Piracicaba, rio por onde sobem os peixes". ${ }^{148}$

Segundo Ercolin, "na linguagem tupi-guarani, ‘Piracicaba’ significa 'lugar onde o peixe chega' ou 'lugar onde o peixe pára', 'lugar onde se ajuntam os peixes', 'rio por onde sobem os peixes'. E que todas essas expressões dão idéia de abundância de peixes". 149

As interpretações são muitas, mas de qualquer modo fica evidente a importância da cultura indígena na própria origem etimológica de Piracicaba.

Como se constata, é muito difícil se chegar a um consenso sobre o real significado do nome da cidade de Piracicaba, mas não se pode deixar de mencionar que, além dos diversos significados atribuídos, há também um apelido para a cidade, "Noiva da Colina".

Diz Elias Neto:

\footnotetext{
${ }^{147}$ MELLO, apud ELIAS NETO, Cecílio. Op. Cit. p. 19.

${ }^{148}$ KRAHENBUHL, Hélio. Almanaque de Piracicaba. p. 11.

${ }^{149}$ ERCOLIN, Giselda. (org.). Op. Cit..p. 00.
} 
O que não podemos deixar de citar é o "apelido" que Piracicaba ganhou com referência a um poema. De acordo com Cecílio Elias Neto, o cognome "Noiva da Colina" foi dado a Piracicaba por Brazílio Machado, em um célebre poema a que ele deu nome de "Piracicaba" que fala do "véu da noiva", que é o "manto da neblina" das noites piracicabanas. ${ }^{150}$

Brazílio Augusto Machado cita o "véu da noiva", referindo-se a um manto de neblina que desce em algumas noites piracicabanas, muitas vezes confundida erradamente com o "véu" formado pela queda d’água do córrego do Mirante, logo abaixo do Salto.

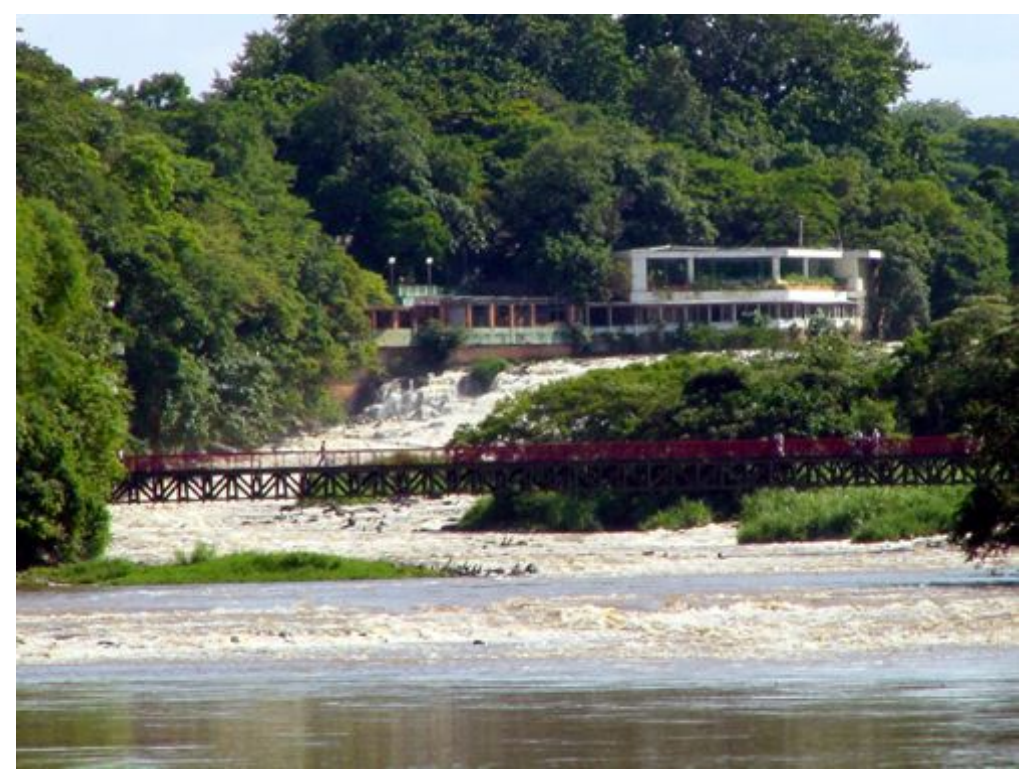

Ponte Pênsil e Salto do rio Piracicaba

Torres, analisando o meio geográfico de Piracicaba desde quando fora o município de Vila Nova da Constituição (10/08/1822), ressalta a importância do rio Piracicaba, de sua navegabilidade e da presença de seus estaleiros. Segundo ela,

A presença dos estaleiros piracicabanos e a fabricação de canoas tornavam a Vila um escoadouro dos produtos agrícolas da região [...] que devem descer para a foz, com os índios canoeiros, únicos que

${ }^{150}$ ELIAS NETO, Cecílio. Op. Cit. p. 24. 
costumavam aparecer no povoado, mas que viviam às margens dos rios Tietê, Paraná e Grande. ${ }^{151}$

A base da cultura cabocla ou caipira, construída ao longo dos séculos na cidade de Piracicaba e região, foi conseqüência do cultivo da relação de influências recíprocas entre os indígenas e os sertanejos.

\subsection{Estrategicamente privilegiada}

A região de Piracicaba tem sido estratégica, não só para os interesses dos grandes grupos políticos e econômicos desde o período colonial, mas também pela sua posição geográfica, o que possibilitou imensas transformações sociais ao longo de dois séculos.

Com o processo de ocupação pelos portugueses e seus descendentes caboclos, a formação de vilas era incentivada pela Coroa Portuguesa com o objetivo de facilitar víveres e munições para o Forte de Iguatemi, nas fronteiras com o Paraguai, e também como parte da estratégia de habitar as margens dos rios Tietê e Paraná.

Essa posição estratégica, determinada pela geografia, ajuda a explicar as imensas transformações sociais operadas ao longo da história na região, resultando no panorama da virada dos séculos $X X$ e XXI, que favorece a multiplicação de expressões da cultura popular em pleno contexto da industrialização e da tecnificação aceleradas. Mais uma vez o rio é o fio que ordena o processo estratégico de ocupação. ${ }^{152}$

Segundo Ercolin, "oficialmente, a primeira tentativa de ocupação da região de Piracicaba ocorreu em 1693 por Pedro Moraes de Cavalcanti. Porém, somente com

${ }^{151}$ TORRES, Maria C.T.M. Aspectos da expansão urbana de Piracicaba nos primeiros anos do Século XX. p. 47.

${ }^{152}$ NEPTUNE, Nordahl Christian. Op. Cit. p. 40. 
a mineração em Mato Grosso a população estabelecida à beira do rio aumentaria". 153

Ercolin menciona ainda que

alguns grupos sertanistas já conheciam uma trilha de índios, que foi transformada na "Estrada Velha do Sertão dos Bilreiros", que se transformaria mais tarde na "Estrada de Gado e Cavalgaduras", que seguia de São Paulo até a zona de mineração de Cuiabá e que, segundo Mario Neme, cruzava a paragem de Capivari, o rio Piracicaba e os "Campos de Araraquara". ${ }^{154}$

Em 1723 foi concedida a sesmaria de terras, que abrange grande parte da atual zona urbana, no pequeno porto local a Felipe Cardoso, um morador de Itu, considerado, assim, um dos primeiros povoadores da cidade, um homem de recursos e de muita iniciativa. Cardoso teria construído a primeira ligação de terra entre Itu e Piracicaba, facilitando a ocupação. Dois anos depois foi concedida uma sesmaria a Luiz Pedroso de Barros, outro importante desbravador, responsável pela construção de um caminho de terra entre São Paulo e Cuiabá. Já em 1726, os primeiros comboios passavam por Piracicaba seguindo o destino à Cuiabá e naturalmente aumentando sua importância após a descoberta das minas de ouro de Minas Gerais, Goiás e Mato Grosso.

De 1733 a 1737, colonizadores e expedições de São Paulo praticamente dizimaram os índios da região oeste paulista e sudeste do Mato Grosso.

Encerrando-se, portanto o ciclo do ouro, os paulistas tiveram de voltar para a região de origem e trabalhar na terra.

\footnotetext{
153 ERCOLIN, Giselda. (org.). Op. Cit.. p.15.

154 Ibid. p. 15.
} 
Percebe-se, no entanto, que o rio Piracicaba fora utilizado havia muitos anos, desde o tempo das bandeiras e entradas. Por ele eram trazidos alimentos, equipamentos e armas.

De acordo com Ercolin,

o rio Piracicaba, grande afluente do Tietê, começou a ser percorrido no período da entradas e bandeiras, quando o Brasil vivia o desbravamento do interior paulista pelos bandeirantes. Por suas características de correr para o interior e não para o mar, o rio Piracicaba foi um dos caminhos do sertão. Por ele seguiam barcos, levando desbravadores, com alimentos, armas e equipamentos. ${ }^{155}$

Em 1766, Antônio Corrêa Barbosa foi o encarregado por Dom Luís Antônio de Souza Botelho e Mourão, capitão-geral de São Paulo, de fundar uma povoação na foz do rio Piracicaba. Primeiramente, o local que Barbosa fundou tal povoado não tinha praticamente nada, apenas viviam índios Paiaguás e também alguns posseiros. Posteriormente, o local ganhou igreja.

Segundo Neme,

Barbosa optou pelo local mais apropriado da região, a margem direita do Salto, a 90 quilômetros da foz, nas imediações de um velho porto, onde habitavam os índios Paiaguás e onde haviam se fixado alguns posseiros. No dia $1^{\circ}$ de Agosto de 1767 era fundado, oficialmente, o povoado que, anos mais tarde (1774), ganhou igreja e foi elevado à condição de "Freguesia de Santo Antônio de Piracicaba". Dez anos depois, o povoado foi transferido para a margem esquerda do rio, logo abaixo do Salto do Piracicaba, onde terras melhores favoreciam sua expansão. ${ }^{156}$

As ruas começaram a aparecer quando foi adquirida junto ao cartório de Itu a área destinada a sediar a comunidade, o plano de arruamento foi feito pelo mestre

\footnotetext{
155 ERCOLIN, Giselda. (org.). Op. Cit.. p. 17.

${ }^{156}$ NEME, Mário. A História da Fundação de Piracicaba. p. 51
} 
entalhador Miguel Francisco Paes Soares, ocorrendo a mudança em 31 de julho de 1784, e a partir daquela data Santo Antônio passou a ser o padroeiro da Freguesia.

\subsection{O poder da cana e o café}

Realizada a mudança, Piracicaba era tão-somente a Rua da Praia (hoje Rua do Porto), permanecendo como principal espaço da comunidade, que continuava ligada ao rio.

Em um processo lento. Piracicaba começou a subir a rampa do picadão, denominada hoje Rua Moraes Barros, em direção à esplanada de Santo Antônio, hoje Praça José Bonifácio, e também num breve período de tempo expandiu a plantação de cana-de-açúcar muito visada pelos espanhóis.

Segundo Neme,

a Freguesia de Piracicaba logo tornou-se uma das principais responsáveis pela expansão da cana-de-açúcar, atividade incentivada por Portugal para garantir a ocupação de um território constantemente ameaçado pelos espanhóis e também por motivos muito concretos economicamente. A cana estava alcançando preços expressivos no mercado internacional no final do século XVIII. ${ }^{157}$

O poder crescente da cana foi responsável pela evolução política.

Segundo Neptune,

Em 1822, a pequena freguesia passou a se chamar Vila da Constituição. Mais tarde (1836), foi designada Vila Nova da Constituição. Nesse momento a identidade local tinha sido abalada pelos interesses políticos da Coroa portuguesa. ${ }^{158}$

\footnotetext{
${ }^{157}$ NEME, Mário. Op. Cit.. p. 51.

158 NEPTUNE, Nordahl Christian. Op. Cit. p. 41.
} 
A partir de 1836, houve um importante período de expansão com muitas plantações de arroz, feijão, milho, algodão e fumo espalhadas pelos campos, além de pastos para criação de gado.

Em 24 de abril de 1856, Vila Nova da Constituição foi elevada à categoria de cidade. A Comarca de Piracicaba foi instalada no dia 30 de março de 1858.

Em 1877, por petição do então vereador Prudente de Moraes, e posteriormente primeiro presidente civil do Brasil, o nome da cidade foi oficialmente mudado para Piracicaba, acentuando o peso da tradição cultural. ${ }^{159}$

De acordo com Ercolin, "havia, então, 1600 casas na área urbana, onde habitavam 4 mil pessoas. A região possuía ao todo mais de 22 mil habitantes e 5 mil escravos, espalhados pelas quatro fazendas de cana-de-açúcar e 29 fazendas de café."160

Apesar de a economia girar em torno dos engenhos, sendo, portanto, uma vida basicamente rural, o núcleo urbano de Piracicaba cresceu de forma mais ou menos rápida no período da cana.

No fim do século XIX, a cidade já se destacava no cenário paulista como o terceiro município em população escrava, a zona rural era bastante expressiva, oferecendo o café como a riqueza nacional e o açúcar proveniente de seus 25 engenhos. Mesmo no auge do surto cafeeiro, Piracicaba nunca deixou de ser um importante pólo açucareiro. De todo modo, o café tornou-se dominante até a queda da Primeira República, em 1930.

A expressiva produção de produtos agrícolas e de aguardente tomava a direção do porto de Santos, buscando os negócios do mercado internacional.

\footnotetext{
${ }^{159}$ ERCOLIN, Giselda. (org.). Op. Cit.. p. 22.

160 lbid.. p. 23.
} 
Piracicaba tornou-se também centro de armazenamento de sal, que servia para abastecer as fazendas de gado da região e lugares de salga de peixe.

Este processo de produção na cidade foi fundamental para o seu crescimento. Foi o momento da história significativo para o aumento populacional, em que imigrantes vieram para trabalhar nas lavouras de café.

Os vinte primeiros anos do século $X X$ foram para Piracicaba 0 período de maior crescimento. De 25.374 habitantes em 1900, a cidade pulou para 67.732 habitantes em 1920, conseqüência dos fluxos imigratórios importados para o trabalho nas lavouras de café. ${ }^{161}$

O nome de Luiz de Souza Queiroz tornou-se lapidar para a história de Piracicaba. Ainda no final do século XIX ele doou a Fazenda São João da Montanha para o governo estadual implantar uma escola agrícola em Piracicaba, necessidade sentida para o aprimoramento do café e de outras culturas. Em 1901, começaram a funcionar os primeiros cursos daquela que seria a futura Escola Superior de Agricultura Luiz de Queiroz (ESALQ), hoje ligada à USP, e que se tornou uma das principais do gênero em toda a América Latina.

${ }^{161}$ ERCOLIN, Giselda. (org.). Op. Cit.. p. 29. 


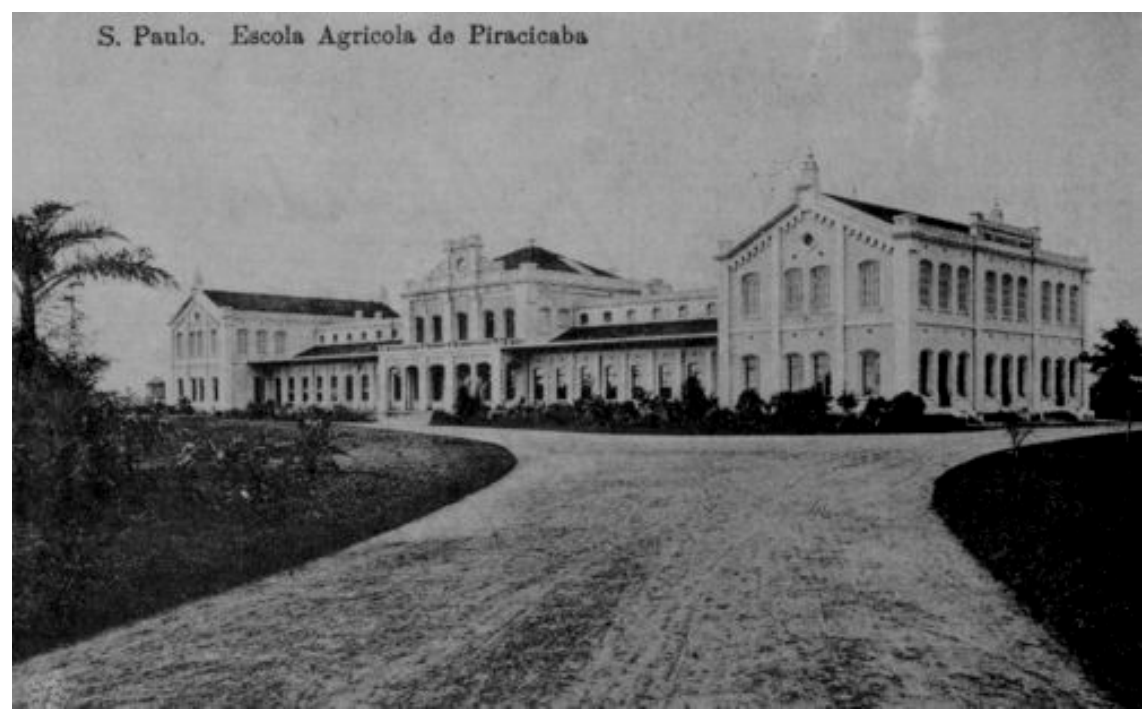

Escola Agrícola Luiz de Queiroz - ESALQ - USP

A escola agrícola alimentou a expansão agrícola e, sobretudo inicialmente, a do café e a da cana, em Piracicaba e região.

O capital dos fazendeiros do café financiou a criação, em 1867, da Companhia Paulista de Estradas de Ferro (conhecida como Ferrovia Paulista), que entrou em operação cinco anos depois e ligava Campinas a Jundiaí, por $44 \mathrm{~km}$. No dia 20de fevereiro de 1877, foi inaugurado o ramal da Sorocabana Railway, ligando o município a Itu, favorecendo o transporte da cana e café de Piracicaba e região até os principais pólos consumidores e ao porto de Santos, visando à exportação. ${ }^{162}$

A região logo se tornou o principal centro ferroviário do Brasil. A estrada de ferro que liga o município a cidade de Itu construída principalmente com o capital proveniente dos fazendeiros de café que aqui estavam instalados.

“Dos 139 km de ferrovias em 1870, ligando Santos a Jundiaí, a rede ferroviária paulista ampliou-se para 3.373 km em 1890 e 6.616 km em 1920, até atingir 7.540 em 1940." 163

\footnotetext{
${ }^{162}$ NEGRI, Barjas. A concentração/desconcentração industrial em São Paulo. p. 24.

163 Ibid.. p. 26.
} 
Também era a época do começo da industrialização com a chegada das primeiras máquinas a vapor, e, de modo paralelo à expansão das ferrovias, evoluiu o interesse estratégico pela navegação fluvial.

Em 1873, a Coroa deu a concessão de exploração comercial pelos rios Piracicaba e Tietê para a Companhia Fluvial Paulista, fato que indicava a recuperação dos rios como importante meio de transporte, a fim de implantar um transporte regular, assim como havia ocorrido no período colonial.

\subsection{Crescimento urbano e surgimento das indústrias}

O crescimento urbano da cidade deu-se devido à ascensão do café, permitindo o aparecimento das indústrias e de uma vida cultural e social mais agitada. Com isso, as necessidades da população se modificaram de alguma maneira. Eis que surge o primeiro jornal, as casas começam a ter números e as calçadas saem da condição de terra. Um teatro fora construído na praça.

Em 1866 surge o primeiro jornal, O Piracicabano. Em 1867, o primeiro centenário de Piracicaba passa despercebido devido à guerra com o Paraguai. Em 1868 as casas da região central passam a ser numeradas e as ruas a ser calçadas com pedras. Em 1870 inicia-se a construção do Teatro Santo Estevão, na Praça da Matriz, pelo Barão de Rezende, inaugurado em 1871. ${ }^{164}$

A construção da ponte sobre o rio Piracicaba em 1875 determinou a formação de um bairro novo, nas terras do barão Estevão de Rezende.

${ }^{164}$ ERCOLIN, Giselda. (org.). Op. Cit. p. 23. 


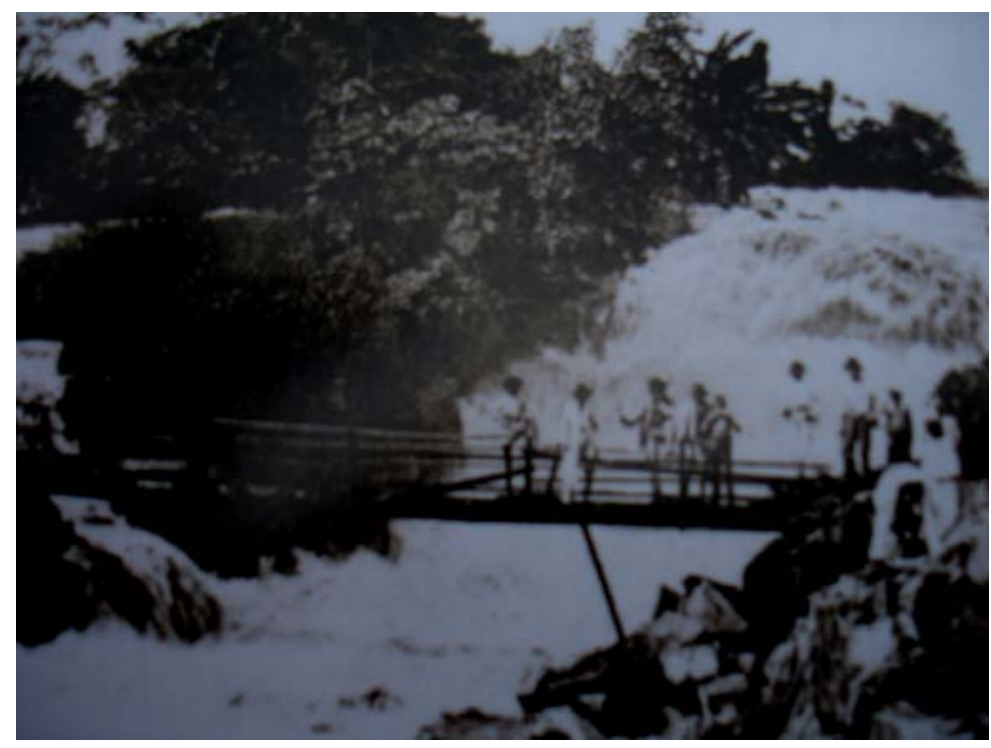

Ponte sobre o rio Piracicaba

Seguindo uma tendência verificada na história do capitalismo, o parque industrial em Piracicaba foi estruturado a partir do setor de tecidos.

Durante o ciclo agrícola do algodão, foram criadas empresas como a Fábrica de Tecidos (Santa Francisca, depois Arethusina e, enfim, Boyes), fundada em 1876, que funcionou com teares e alguns operários importados da Europa.

A Estrada de ferro, já referida anteriormente, também contribuiu com o surgimento de usinas, como a do Engenho Central, a de Monte Alegre e a de Capivari, e também foi responsável por formar pequenos povoados à sua volta.

Com a inauguração da Estrada de Ferro Ituana, em 20 de fevereiro de 1877, surgiram pequenos povoados à margem dos trilhos e foram instaladas as primeiras usinas açucareiras, entre elas o Engenho Central em 1881, que representou um avanço na estrutura produtiva, pois industrializava a cana de forma centralizada e com equipamentos modernos, o Engenho de Capivari em 1894 e a Usina Monte Alegre em 1890. ${ }^{165}$

${ }^{165}$ ERCOLIN, Giselda. (org.). Op. Cit. p. 25. 
É importante destacar as imigrações que aconteceram naquele período, pois assim muitos estrangeiros estabeleceram-se no campo e na cidade, ativando o pequeno comercio e introduzindo novos costumes.

Entre os imigrantes destacam-se os portugueses; os espanhóis; os árabes, que chegaram à região por volta de 1878 a 1880; os japoneses, que moraram na Fazenda Pau D'alho e fundaram a Associação Japonesa de Piracicaba em 1926; e os italianos, que se destacaram pela forte contribuição demográfica e cultural desde o início do século XX.

Em 1881, a cidade acolheu a Igreja Metodista, tornando-se uma propulsora do ensino no município, e presenciou o surgimento do jornal A Gazeta, com participação ativa até 1937.

Em 1889, foi implantada a telefonia. Em 1893, seguindo-se ao exemplo pioneiro de Luiz de Queiroz, que em 1884 já havia usado eletricidade em sua residência, foi a vez da iluminação pública. Piracicaba desenvolvia-se rapidamente. Em decorrência do açúcar produzido na região, houve a necessidade de ampliação no setor agroindustrial.

Segundo Mourão,

no início do século $X X$ surgiam também os primeiros bondes trazidos pela South Eletric Company e as primeiras fábricas de acessórios para usinas implantadas pelo grupo empresarial local, a Dedini. Consolidado esse quadro, Piracicaba chegava aos anos $50 \mathrm{com}$ um complexo agroindustrial desenvolvido, quando passou a ser conhecida como "A Capital do Açúcar". Esse surto de industrialização promoveu uma intensa migração rural-urbana nos anos que se seguiram. ${ }^{166}$

\footnotetext{
${ }^{166}$ MOURÃO, Júlio O. F. apud NEPTUNE, Nordahl Christian. Op. Cit. p. 45 e 46.
} 
A partir de 1970, o capitalismo paulista comandou a transferência da indústria pesada da metrópole para o interior. Desenvolveu-se então um importante processo de diversificação econômica no município, com a implantação de um parque industrial complexo. Nesse cenário, destacaram-se as indústrias mecânicas e de maquinário agrícola, metalúrgica, de papel e papelão.

A vinda de multinacionais, modernas empresas de capital estrangeiro de novos segmentos industriais, complementou este processo. Além disso, a criação do Pró-Álcool,em 1975, deu um grande impulso às usinas e destilarias, historicamente fortes na região, promovendo o desenvolvimento do parque industrial voltado para o setor canavieiro.

De acordo com Neptune, atualmente

Piracicaba é uma importante base de empresas globais (General Motors, Carrefour, Caterpillar, Siderúrgica Belgo-Mineira, Delphi Energy and Engine Management Systems, entre outras), ocupando posição de destaque entre os municípios da região. Depois da crise econômica do começo dos anos 90, que atingiu todo o país, Piracicaba vem experimentando, desde 1991, um crescimento econômico moderado, mas constante, da ordem de $3 \%$ ao ano, segundo a Secretaria Municipal de Finanças de Piracicaba. ${ }^{167}$

\subsection{Tradição e fé contra as doenças}

O rápido crescimento do núcleo urbano de Piracicaba não era acompanhado pelas necessárias medidas sanitárias. As condições ideais para a proliferação de doenças tropicais estavam sendo formadas, somando-se a isso o ritmo intensivo dos desmatamentos exigidos pela expansão da cobertura verde da cana. Com os desmatamentos, aumentava a migração de vetores de doenças de seus antigos

\footnotetext{
${ }^{167}$ NEPTUNE, Nordahl Christian. Op. Cit. p. 46.
} 
habitats naturais para a povoação, como ficaria comprovado pela ciência através dos tempos.

Epidemias tropicais e outras doenças típicas, como chagas e malária, tornaram-se freqüentes entre os moradores.

Segundo Neptune,

foi nos rituais religiosos que os descendentes dos índios e caboclos encontraram a forma de resistir às doenças. O rio Piracicaba tornouse, novamente, o espaço adequado para o evento que se consagraria como a principal festa religiosa popular da cidade e que, de certa maneira, marcou de modo especial a cultura e a espiritualidade dos piracicabanos: a Festa do Divino, tradição lusitana adaptada à realidade tupiniquim, cujo objetivo era agradecer e pedir a Deus pela cura dos males da época, como a doença-dechagas e a malária. A Festa do Divino já nasceu, nesse contexto, como um símbolo da resistência da cultura popular, herdeira das tradições indígenas, católicas e das culturas autóctones e cabocla. ${ }^{168}$

Alguns pesquisadores descrevem que a Festa do Divino originou-se no século XIII, em Portugal, através do culto divulgado pela rainha Santa Helena, em honra e glória à Terceira Pessoa da Santíssima Trindade, o Espírito Santo.

Segundo Perecin,

o culto e a Festa foram repassados às colônias portuguesas e chegaram ao Brasil no século XVIII, quando foram introduzidos na Capitania de São Paulo,atingindo as comunidades ribeirinhas do rio Tietê, onde faltava de tudo e sobrava sofrimento, principalmente as febres, além da fé. ${ }^{169}$

A Bandeira do Espírito Santo chegou cedo a Piracicaba, embora a Festa só tenha sido registrada em 1826. O encontro dos barcos, de forma associada ao generoso consumo de comidas e às danças típicas, materializou a vinculação dos

\footnotetext{
168 NEPTUNE, Nordahl Christian. Op. Cit. p. 47.

169 PERECIN. Marly T. G. "173a Festa do Divino Espírito Santo", Prefeitura Municipal de Piracicaba, Secretaria de Ação Cultural. Piracicaba, jul. 1999.
} 
moradores com o seu rio e com as suas tradições culturais e religiosas mais profundas.

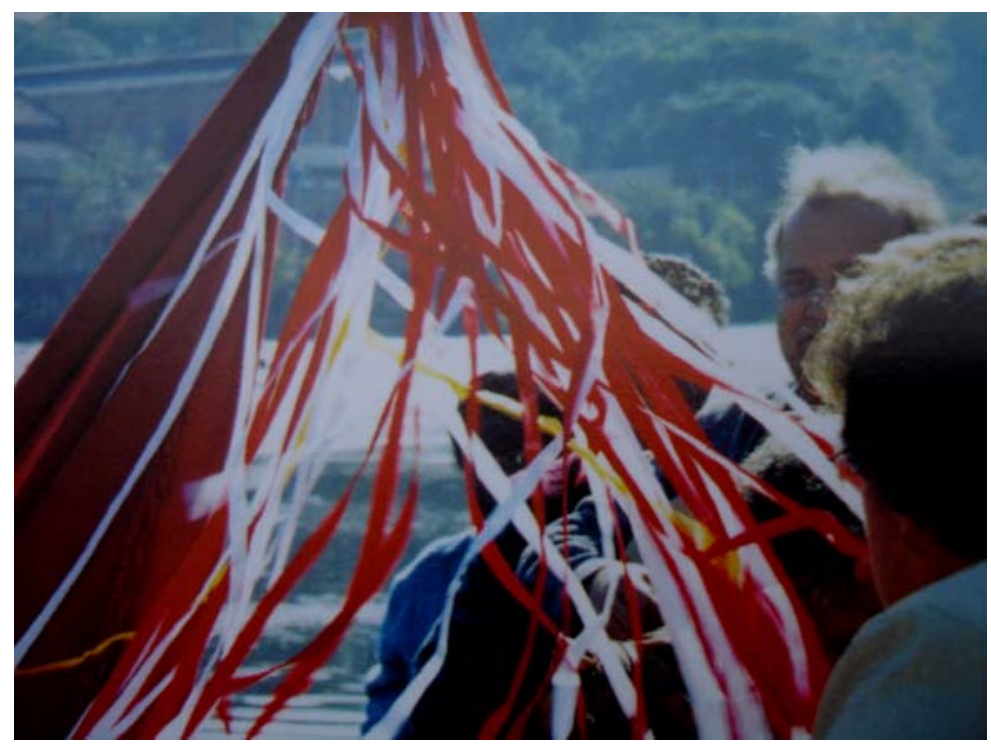

Bandeira do Divino

A Festa do Divino é realizada em etapas: Folia, Pouso, Leilão, Encontro das Bandeiras e Procissão.

$\mathrm{Na}$ Folia, os devotos carregam a Bandeira do Divino, formando o "bando precatório", para percorrer as casas em busca de prendas, votos ou "promessas". A Bandeira vai à frente, carregada atrás, vai a charanga, constituída de homens, mulheres e crianças. O canto é bastante triste. O Leilão, feito na sexta-feira (em Piracicaba, no Largo dos Pescadores), antecede o Encontro e é posterior ao Pouso. ${ }^{170}$

Depois de 176 anos, o ritual é o mesmo. O ponto alto é o encontro no meio do rio dos barcos com seus remadores: os Irmãos do Divino ou do Bairro do RioAcima, trajados de azul e com detalhes em branco, e os Irmãos do Pouso ou do Bairro do Rio-Abaixo, vestidos em vermelho e branco. Além do encontro dos devotos, com as respectivas Bandeiras, a festa inclui também a novena, a Folia do

${ }^{170}$ ERCOLIN, Giselda. (org.). Op. Cit.. p. 88. 
Divino, a bênção dos barcos, as promessas, a farta distribuição de carne no último dia e as rodas de Cururu.

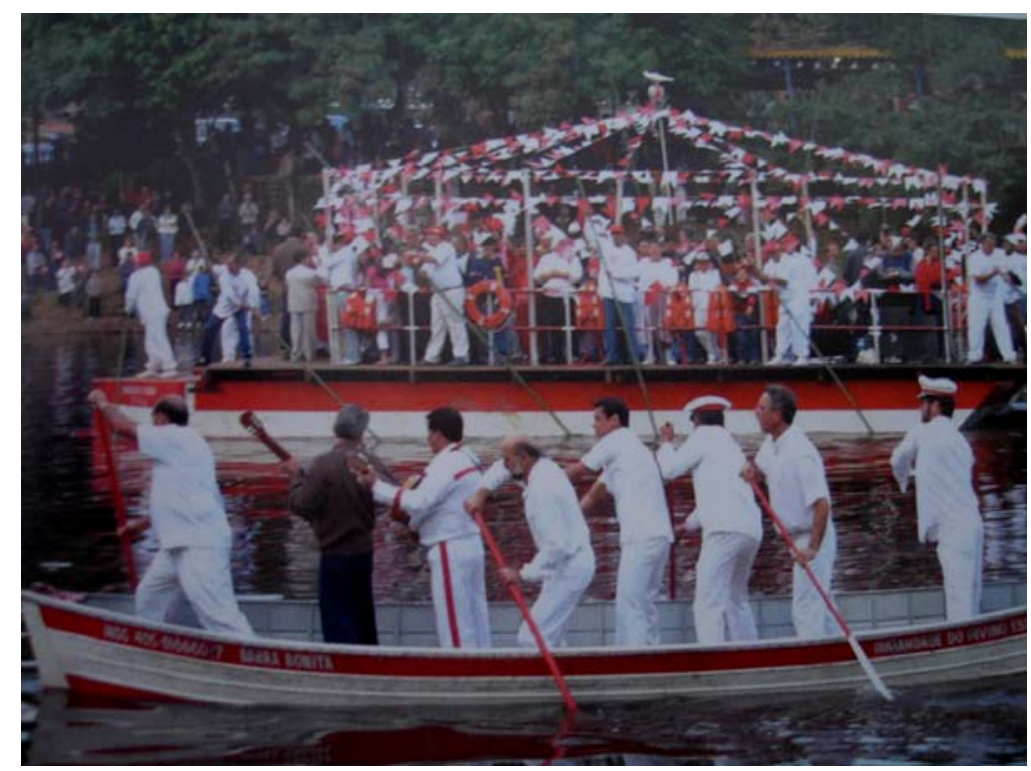

Encontro das Bandeiras

\subsection{Rua da Praia e do Porto}

A Rua do Porto (ex-Rua da Praia) é habitada por pescadores e construtores de barcos. Considerada também área de preservação histórica, conserva toda a tradição e o aspecto original da região ribeirinha. Pescadores que ali resistem, como também nas pequenas casas construídas na região central próxima ao rio, contam histórias sobre o rio e a cidade.

Se o rio Piracicaba é o fio da meada que costurou a cultura local, a Rua do Porto é o pedaço de tecido mais nobre dessa confecção. Enquanto lembrança de um modo de vida singular que torna o cotidiano menos monótono, a rua compõe uma esfera de significação social que faz mais do que separar contextos e configurar atitudes, contém visões de mundo ou éticas que são particulares. Ela é uma 
espécie de síntese do imaginário coletivo, dos sonhos e valores da comunidade local. ${ }^{171}$

Desde o início da povoação, era à beira-rio que a vida acontecia. Gente de toda estirpe circulava pela então Rua da Praia, enquanto os batelões chegavam cheios de cargas que ficavam no depósito da Companhia Fluvial, um barracão que viria a ser mais tarde o Clube Regatas, clube extinto na década de 1980.

Segundo Chiarini,

o nome "Rua da Praia" veio do fato de que, à margem esquerda do rio, atracavam vapores que puxavam as chatas, que eram um tipo de embarcação que transportava madeira e areia da "Estação Prainha", junto a atual Bacia do Piracicaba, em terras do Município de São Pedro. ${ }^{172}$

Até a metade do século XIX, segundo o historiador e folclorista Hugo $P$. Carradore,

essa rua possuía apenas sete casebres feitos de pau-a-pique, habitados por pessoas que se dedicavam à pesca, única ocupação de então. A população era pobre, de poucos imigrantes, com uma presença significativa de negros, demonstrando um nítido recorte de discriminação social. ${ }^{173}$

\footnotetext{
${ }^{171}$ NEPTUNE, Nordahl Christian. Op. Cit. p. 50.

${ }^{172}$ GUIDOTI, José Luiz. Navegando pelo Piracicaba. p. 91.

${ }^{173}$ CARRADORE, Hugo P. apud NEPTUNE, Nordahl Christian. Op. Cit. p. 51.
} 


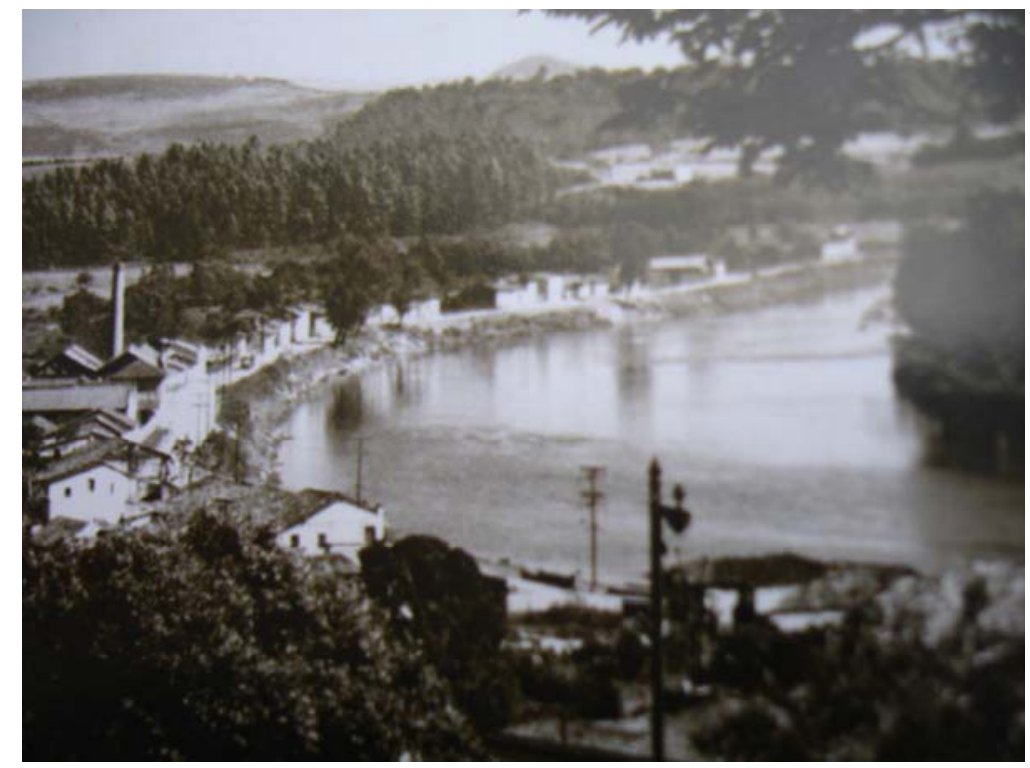

Vista da Rua do Porto

Em seus estudos sobre a fundação da cidade, Perecin afirma que, no início do século $X X$, a maior parte da população urbana freqüentava essa rua e o Largo dos Pescadores, local onde cavaleiros e tropeiros vindos do sertão abasteciam-se ou trocavam as suas mercadorias, descansavam ou partiam para Itu ou Santos. Geralmente, naquele mesmo lugar, ouviam-se modinhas de viola, dançava-se o Batuque com as mucamas, jovens escravas negras. Os homens também dançavam o Cateretê ou Catira - dança rural, cujo nome indica origem tupi, mas que coreograficamente se mostra muito influenciada pelos processos africanos de dançar - ou partia-se para os desafios - repentes - e as rodas de cururu. 


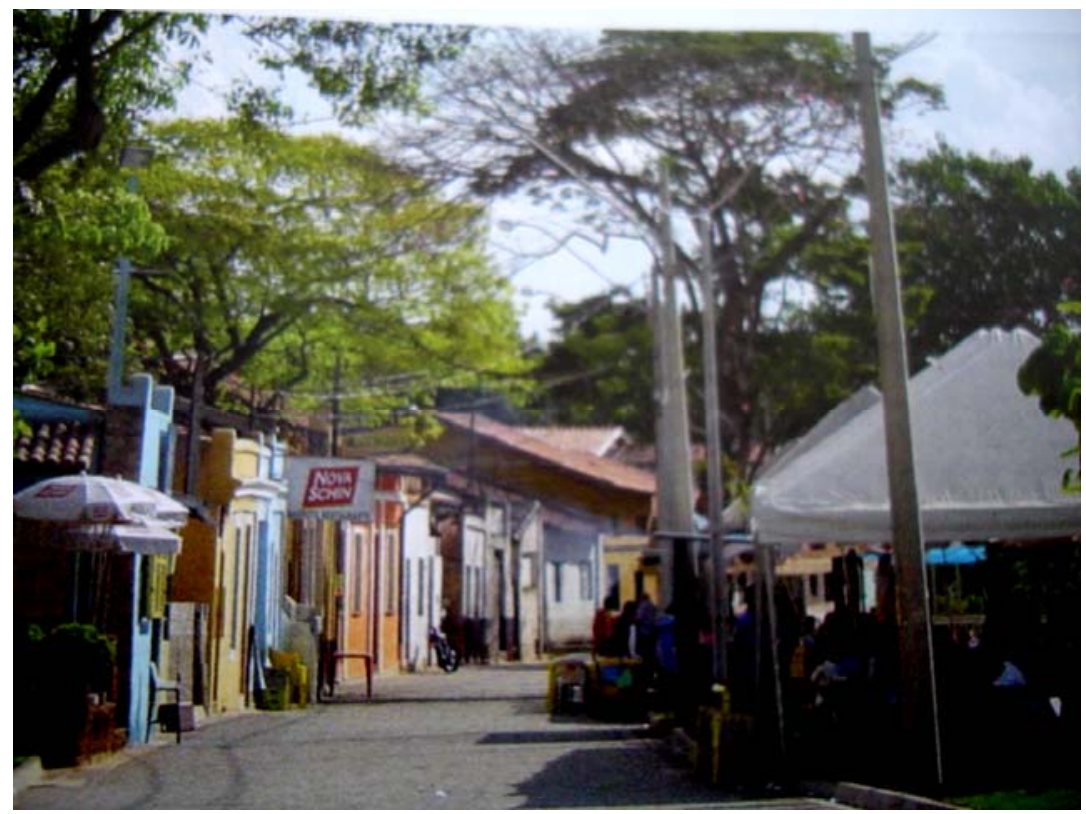

Calçadão da Rua do Porto

Hoje ali se concentram inúmeros bares rústicos e típicos, que oferecem em seus cardápios peixes fritos e a famosa pinga de Piracicaba. Em algumas casas são vendidas iscas e varas para a pesca e, junto à margem do rio, há o calçadão, com quiosques para que turistas e moradores locais possam saborear os pratos típicos como peixes, cuscuz, além das músicas da região, em especial o cururu, que tem grande grau de identificação com o local. 
CAPITULO IV

AS RÁDIOS DE PIRACICABA E SUAS RELAÇÕES COM O CURURU 


\section{As rádios de Piracicaba e suas relações com o cururu}

\subsection{As rádios de Piracicaba}

Piracicaba é uma cidade com forte tradição no campo da comunicação radiofônica, tendo entre as suas emissoras a sexta mais antiga do Brasil, a Rádio Difusora, instalada oficialmente em 12 de outubro de 1933, por João Sampaio Góes, apenas dez anos após a inauguração da Rádio Sociedade do Rio de Janeiro, considerada a pioneira.

A cidade possui sete emissoras de maior destaque, das quais três AMs e quatro FMs. As emissoras de AM são a Difusora, Educadora e Rádio Globo (antiga Alvorada). Já as emissoras que retransmitem em FM são a Educativa FM, a Jovem Pan, a 97 FM (associada à Rádio Alvorada) e a Difusora.

A Rádio Globo AM, antiga Alvorada, oferece uma programação que é realizada pela Matriz em São Paulo, com apenas cinco horas de programação local, dividida entre programas de jornalismo, esporte e musical com boletins de informação. As demais emissoras de rádio AM, de uma maneira geral, mantêm programação musical, programas de jornalismo (todas com equipes próprias), programas de variedades, com música e entrevistas, e possuem também equipes esportivas bastante tradicionais, que acompanham as atividades do Esporte Clube XV de Novembro e dos campeonatos de futebol amador e de várzea da cidade.

No caso das emissoras de FM, é necessário salientar que um dos canais vem operando em rede nacional, retransmitindo a Jovem Pan, que possui uma segmentação claramente definida para o público jovem. A 97 FM, hoje, arrendada para a Igreja Universal do Reino de Deus, possui uma programação evangélica voltada para o público da lgreja. A Rádio Difusora possui programação diversificada, estruturada ao nível local, enquanto a 
Educativa FM atua com programação musical, jornalismo e também como instrumento de prestação de contas da Administração Pública Municipal.

É importante também ressaltar as dificuldades para obtenção de informações sobre a história da radiodifusão em Piracicaba, pois as emissoras não possuem arquivos de documentos e de material que se produziu ao longo dos anos. A maioria dos dados, obtidos por poucos pesquisadores que têm se dedicado ao tema, no período mais recente, é proveniente de artigos e reportagens publicadas em jornais e revistas locais e também de depoimentos de ex-funcionários, funcionários e proprietários das empresas de rádio.

Torna-se, portanto, um desafio para os pesquisadores que se interessam pela história do rádio em Piracicaba.

\subsubsection{Difusora AM/FM}

Em 12 de outubro de 1933 chegava a Piracicaba, como Rádio Clube, a primeira emissora de rádio e a décima quinta emissora do Brasil. Em 1944 passou a ser chamada de Rádio Difusora de Piracicaba, sob o comando de seu fundador, João Sampaio Góes, sendo em 1950 adquirida pelo senhor Aristides Figueiredo e sua esposa, Maria Conceição Figueiredo, que já possuíam uma rádio em Uberlândia, Minas Gerais.

De acordo com a revista comemorativa dos 70 anos da emissora,

foi nessa fase que a Difusora passou a movimentar mais sua programação, com a implantação de rádio-novela, novos programas de auditório e grandes shows com orquestras e artistas famosos da Rádio Nacional como Nélson Gonçalves, Marlene, Ângela Maria, Emilinha Borba, Carlos Galhardo e outros. $^{174}$

174 PETROCELLI, Mauricio. Setenta anos da Rádio Difusora, Piracicaba., Dez. de 2003. p. 04. 
Passaram pela Rádio Difusora, nesses 70 anos de existência, nomes que hoje são destaques no cenário da comunicação brasileira e que fizeram história na emissora, como "os apresentadores Léo Batista, Ivo Morgante e Paulo Leoni, o ator Francisco Milani, os repórteres Gil Gomes e Roberto Souza, na época J. Souza, e o narrador esportivo Fiori Gigliotti."

Em 1965, após a morte de seu diretor em 1962, o senhor Aristides Figueiredo, assumiu como diretor o senhor José Roberto Soave, tornando-a uma rádio bem equipada, investindo nas transmissões de jogos e no jornalismo, dedicada a prestação de serviços à comunidade.

A partir da Década de 70, os shows de auditório começaram a se extinguir, e para atrair o ouvinte, investiram no jornalismo e nas Gincanas organizadas pela própria Rádio. "As gincanas passaram a mobilizar uma multidão de pessoas e duraram cerca de dez anos", diz Attinilo José, radialista há mais de 40 anos. ${ }^{175}$

Com o passar do tempo, as disputas nas gincanas tomaram uma grande proporção e algumas equipes transformaram-se em escolas de samba que fizeram muito sucesso nos anos de ouro do carnaval de Piracicaba.

Outro pioneirismo da Difusora e foi a implantação da FM - Freqüência Modulada em 1977, operando em 102,3 MHz.

Depois de visitar algumas estações de FM nos Estados Unidos, José Roberto Soave importou todos os equipamentos necessários para a inauguração, e, na mesma época, substituiu e modernizou toda a aparelhagem da AM, tornando-a, outra vez, referência para o interior de São Paulo e de outros estados.

${ }^{175}$ PETROCELLI, Mauricio. Op. Cit.. p. 05. 
"Em 1997, devido ao falecimento do senhor José Roberto Soave, assumiu a direção da Rádio sua filha Roberta Soave Piva, juntamente com suas irmãs Andréa Soave, gerente comercial, e Daniela Soave, gerente financeira."176

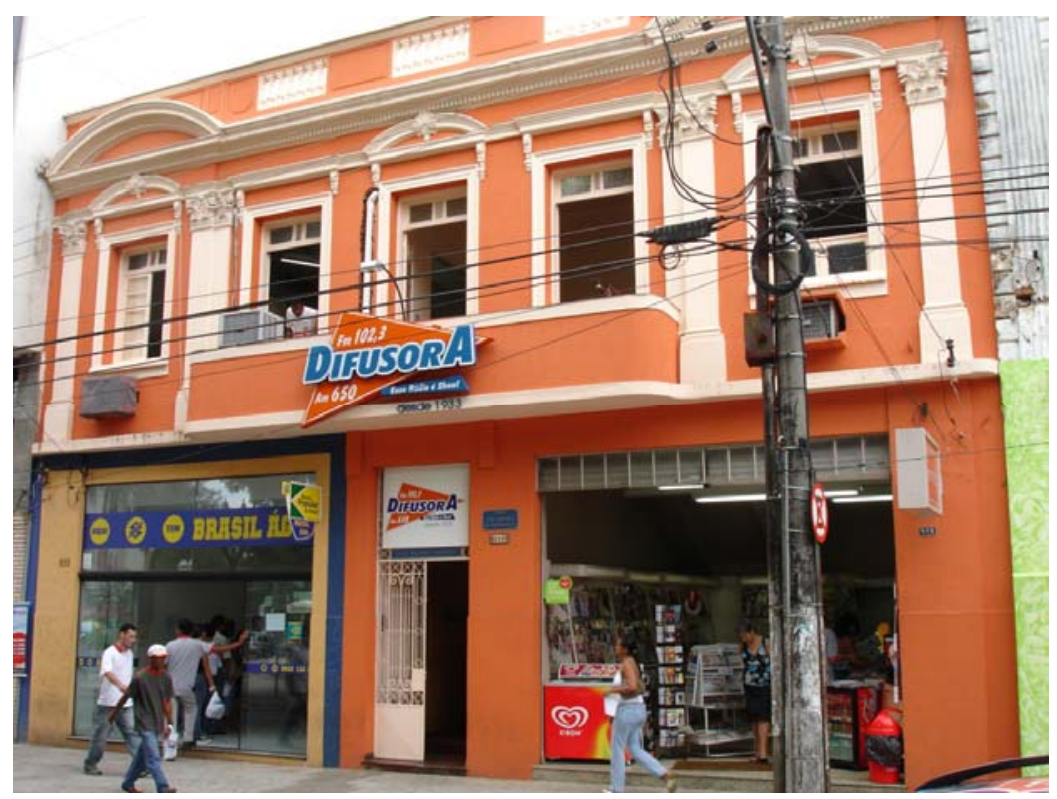

Fachada da Rádio Difusora

Segundo informações contidas no site da rádio (ver anexo),

a Difusora AM, além de um jornalismo forte e dinâmico, possui uma programação alegre e descontraída voltada para o público feminino, donas-de-casa acima dos 25 anos, com gincanas, prêmios e também pedidos musicais feita pelo público. O esporte e jornalismo também atraem um grande número de ouvintes. ${ }^{177}$

Sua potência de 5.000 watts lhe permite atingir cidades a um raio de $150 \mathrm{~km}$.

Dentre estas cidades, destacam-se São Pedro, Águas de São Pedro, Americana, Santa Bárbara, Rio Claro, Tietê, Rio das Pedras, Saltinho, Capivari, Sumaré, Tatuí, Charqueada, Leme, Araras, Cerquilho, Laranjal Paulista, Iracemápolis, Santa Maria da Serra, Campinas, Santo Antonio de Posse, Itapetininga, Porto Feliz, Elias Fausto,

\footnotetext{
${ }^{176}$ ERCOLIN, Giselda. (org.). Op. Cit..p. 80.

177 Site: www.rdifusora.com.br. Acesso em: 16 nov. 2006.
} 
Anhembi, Conchas, Mombuca, Torrinha, Ipeúna, Porto Ferreira, Botucatu, Brotas,

São Manuel, Artur, Nogueira, Analândia, Amparo, Boituva, Cordeirópolis, Corumbataí, Cesário Lange, Mogi Mirim, Mogi Guaçu, Itirapina, Itapeva, Dois Córregos, Monte Mor, Maristela, Rafard, Valinhos, Vinhedo, Holambra, Hortolândia, Louveira, Bofete, Barra Bonita, Igaraçu do Tietê, Mineiros do Tietê.

\begin{abstract}
A Difusora FM possui uma programação musical em estilo Hit Parade (sucessos) dirigida ao público feminino na faixa etária dos 10 aos 49 anos. Com variedade musical, promoções, quadros com a participação do ouvinte e prêmios, o que vem colocando a rádio em lugar de destaque na cidade.

A emissora FM conta com uma plástica moderna e dinâmica, compatível com o lugar que ocupa entre as principais emissoras do país. ${ }^{178}$
\end{abstract}

\title{
4.1.2 FM Municipal/Educativa FM
}

A Educativa FM, hoje 105,9MHz é a única emissora pública e educativa da cidade.

Outorgada pelo governo federal à prefeitura do município, esse serviço público de radiodifusão denominado Serviço de Tecnologia Educacionais tornou-se conhecido pelo seu nome fantasia, Piracicaba FM Municipal.

A emissora iniciou oficialmente suas transmissões no dia 7 de março de 1988, operando em 105,7MHz. A inauguração das instalações no prédio do Semae Serviço Municipal de Água e Esgoto aconteceu em 7 de maio de 1988.

Sua primeira transmissão foi marcada pela formalidade e pelo caráter oficial que acabou sendo a característica do seu primeiro período de atuação, durante a gestão do prefeito Adilson Maluf.

${ }^{178}$ Site: www.rdifusora.com.br. Acesso em: 16 nov.2006. 
O projeto de concepção e implantação da emissora, de acordo com Tomazielo, teve início pelo menos dois anos antes, tempo necessário para que se tomassem todas as medidas legais e se garantisse a sua instalação física, em prédio cedido pelo Semae, à Rua XV de Novembro, 2.200, no Bairro Alto, apostando no seu potencial como instrumento de comunicação entre a administração municipal e a população.

Como estratégia de tramitação na Câmara de Vereadores, o projeto foi inicialmente denominado Teleducação e alocado na Secretaria Municipal de Educação, cujo orçamento permitiria o seu pleno desenvolvimento, na medida em que os seus gastos poderiam ser incluídos no montante. Posteriormente, foi alterado pelos próprios vereadores para Serviço de Tecnologias Educacionais, nome que permanece até hoje, a fim de que não fosse confundido com uma emissora de televisão. Após a aprovação do projeto, foi nomeado o primeiro conselho consultivo da emissora, formado pelo advogado João Basílio, pelo comerciante Italo Bérgamo e pelo radialista Jamil Neto.

Ressalta-se também, em relação a este primeiro período da história da emissora, o fato de ser bastante fechada à participação da comunidade, apesar do seu caráter de rádio público; apresentava uma programação com muita música, não contava com a participação da população, sem espaço aberto para que a comunidade expressasse a sua cultura, sua participação política na cidade.

O slogan Pela gente da terra e pela terra da gente, que acompanha a Rádio Piracicaba FM Municipal, foi criado pelo radialista Paulo de Tarso Porreli, o "Lô Porreli", um profissional que já atuava na emissora como repórter desde a sua fundação, quando a administração do prefeito José Machado assumiu a sua direção, em 1989.

A sua implantação ocorreu gradativamente, com a gravação de vinhetas que apareciam constantemente em sua programação, demonstrando uma primeira percepção que os próprios funcionários da emissora tiveram em relação da nova linha que começava a ser implantada, que tinha entre suas fontes de inspiração os ideais de Roquete Pinto, que ao fundar a sua Rádio 
Sociedade, no início do século, no Rio de Janeiro, buscava um instrumento de resgate da cultura e de difusão educativa para o povo brasileiro. ${ }^{179}$

O dia 4 de agosto de 1999 constitui um marco histórico para a emissora, quando conquistou sua sede própria.

Em janeiro de 2001, uma nova diretoria assume a emissora com a proposta de promover inovações na programação e modernizar seus equipamentos e estrutura. Entre essas mudanças destacam-se a troca do nome fantasia "Piracicaba Fm Municipal" para "Educativa FM"; a implantação de novas tecnologias; as novas produções artísticas; a informatização; investimento na capacitação de funcionários e aquisição de novo transmissor. Essa inovação tem colocado a rádio Educativa $\mathrm{FM}$ entre as mais progressistas no serviço de radiodifusão educativo. ${ }^{180}$



Fachada da Rádio Educativa FM

179 TOMAZIELLO, Paulo Sergio e SANTANA, Ricardo A. F. Radiodifusão, cultura e participação popular: a valorização do local pela Rádio FM Municipal de Piracicaba. II Encontro Nacional da Rede Alfredo de Carvalho 2004.

${ }^{180}$ ERCOLIN, Giselda. (org.). Op. Cit. p. 80. 
Segundo pesquisa efetuada no site da rádio, observa-se que a programação inicial da emissora era musical e jornalística, com forte presença de música brasileira e instrumental.

\begin{abstract}
Entre os anos de 1989 até 1992, a emissora inova com a participação popular e com a valorização da cultura local e regional. Do ano de 1993 até 2000 predomina a música local, brasileira e a internacional; programas de secretarias municipais e jornalísticos.

Em relação à audiência, destaca-se, no site, que mais de um milhão de pessoas entre as cidades de Piracicaba, Rio Claro, Limeira, Americana, Santa Bárbara D'Oeste, Rio das Pedras, São Pedro, Águas de São Pedro, Serra Negra entre outras, estão sintonizadas na Educativa FM. ${ }^{181}$
\end{abstract}

Sua programação (anexa a este trabalho) é de 24 horas de músicas, notícias e entretenimento para os ouvintes ávidos por uma programação de alto nível e alternativa às emissoras comerciais. Os programas temáticos da Educativa FM estão fundamentados na educação, entretenimento, informação e cultura, com destaque ao programa Nossa Terra, Nossa Gente, que vai ao ar todos os domingos com apresentação de cururu e moda-de-viola.

\title{
4.1.3 Educadora AM
}

No ano de 1967, amantes da cultura e da música, os doutores Nelson Meirelles (médico), Fortunato Losso Netto (médico e jornalista), Ernesto Pereira Lopes (empresário e deputado), Coriolano Ferraz Meirelles (advogado) e Jairo Ribeiro de Mattos (engenheiro), reuniram-se para montar uma emissora de ondas médias na cidade de Piracicaba.

\footnotetext{
${ }^{181}$ Site www.educativafm.com.br. Acesso em 07 nov. 2006.
} 
A concessão federal desta emissora foi conquistada pelo grupo junto ao Congresso Nacional sendo ela inaugurada em $1^{\circ}$ de agosto de 1967 e denominada Rádio Educadora de Piracicaba, operada em ZYK 533 faixa AM e estúdios localizados no centro de Piracicaba na rua São José. ${ }^{182}$

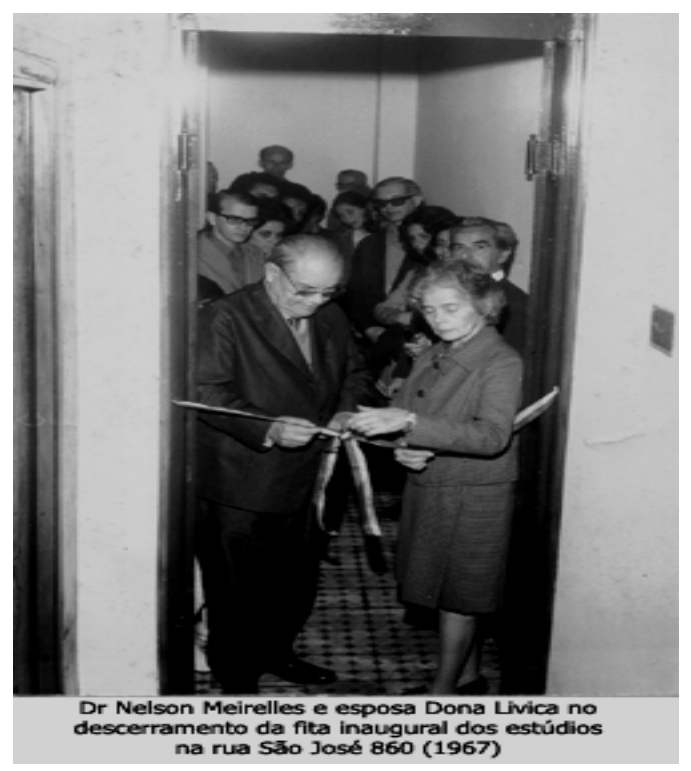

A Educadora AM desde 1975 é comandada pela família Meirelles de Mattos, tendo como acionistas majoritários Jairo Ribeiro de Mattos e Anna Maria Meirelles de Mattos e seus quatro filhos.

Em 2000 afiliou-se à Rede Jovem Pan SAT AM, e detêm parcela significativa da audiência em toda região com locutores consagrados, transmissão dos jogos do XV e prestação de serviços. ${ }^{183}$

A programação da rádio, anexa a este trabalho, inclui, junto com os programas de músicas atuais, transmissões de missas católicas e musical religioso, o que já não é tão comum nas rádios de Piracicaba, além de programas de músicas clássicas, sertanejo raiz e cururu, tornando-a uma rádio mais tradicional.

\footnotetext{
${ }^{182}$ Site www.educadora1060.com.br. Acesso em 18 nov. 2006.

${ }^{183}$ Site www.educadora1060.com.br. Acesso em 18 nov. 2006.
} 
"A Educadora sempre teve uma programação com espaço reservado para o esporte e para a cultura, tanto para a música clássica como para o cururu", complementa o proprietário Jairo Mattos.

Vale ressaltar que, além dos programas locais, a Rádio Educadora conta também com programas da rede Jovem Pan Sat, como, por exemplo, o Futebol ao Vivo; Jornada Esportiva; Hora da Verdade JP e Agência Nacional (jornalismo), inseridos na programação.

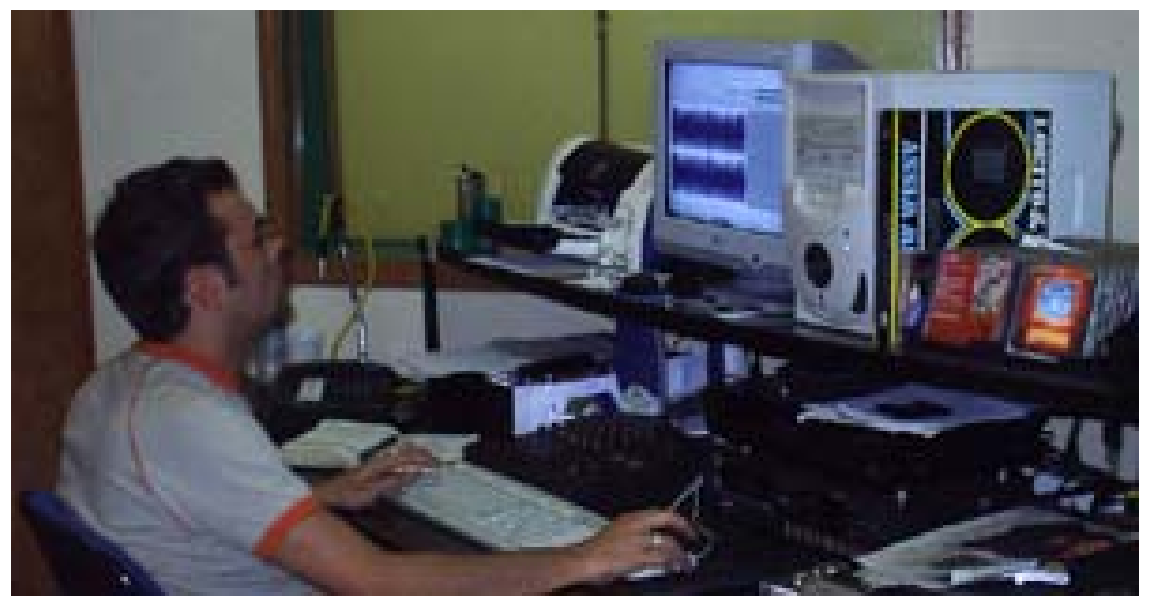

Estúdio da Educadora AM

Alguns locutores de destaque fizeram história na rádio, como o grande cururueiro Nhô Serra, que apresentou o programa de cururu no início de suas transmissões, hoje apresentado por Moacir Bombo, e outros que ainda fazem parte da Rádio, como "Titio" Luiz, que apresenta o Programa da Amizade; Dario Corrêa, com o programa Chapéu de Palha; a dupla sertaneja Craveiro e Cravinho, entre outros. 


\subsubsection{Educadora FM/Jovem Pan}

A rádio Educadora FM $(103,1 \mathrm{MHz})$ foi inaugurada no começo da década de 1980, começando suas transmissões na chácara de seu proprietário, Jairo Mattos, no Bairro Dois Córregos.

Em fase de experimentação, a primeira atração a ser transmitida foi o programa Chapéu de Palha, comandado até hoje na Educadora AM pelo locutor Dario Corrêa.

Logo, a emissora mudou-se para o prédio em que já se encontrava instalada a Educadora AM, na Rua Boa Morte, no centro da cidade de Piracicaba, fixando em um mesmo prédio as duas emissoras.

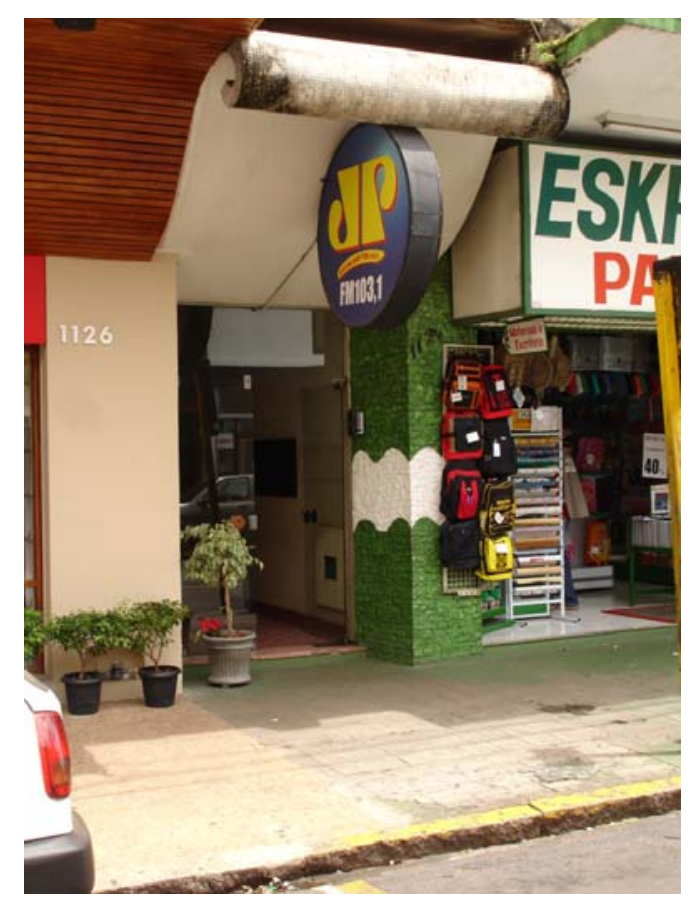

Fachada da Educadora AM e Jovem Pan FM

Em 1994, a rádio paulistana Jovem Pan iniciava seu projeto de criar uma rede via satélite destinada ao público jovem. Foi então que há 11 anos, em 1996 
especificamente, a Educadora FM filiou-se à Jovem Pan Sat de São Paulo, sendo a primeira afiliada no país da Rádio Jovem Pan, com a qual mantém parceria até hoje.

Mesmo sendo uma repetidora da rede Jovem Pan, a rádio possui determinados horários para inserção de uma programação local - no caso desta emissora, os programas locais têm o mesmo segmento dos programas que chegam via satélite, com músicas da atualidade, sem espaço para estilos musicais como samba, música sertaneja, forró, música erudita ou até mesmo o cururu, entre outros, mantendo na maioria de sua programação o estilo pop.

O espaço aberto à programação local conta também com boletins de informações e propagandas locais.

\subsubsection{Alvorada AM (Globo)}

Na busca por um acervo histórico sobre as rádios Alvorada AM e FM, tanto em bibliotecas, jornais e revistas da cidade quanto nas próprias emissoras, não foram encontrados documentos que relatem suas histórias, dificultando esta pesquisa. No que diz respeito ao quadro de funcionários que trabalhavam nas emissoras, antes de as emissoras se filiarem à Rádio Globo, apenas Galhardo está em atividade e não participou de todo o processo histórico das rádios.

De acordo com Tomaziello, em rápida citação no artigo intitulado Valorização das Culturas Local e Regional no Rádio Piracicabano,

a Rádio Alvorada (AM) foi inaugurada em 17 de agosto de 1957, com o nome de Rádio Voz Agrícola, através do grupo Piratininga, de São Paulo. Sua programação é bastante diversificada, visando atingir principalmente as camadas mais pobres da população, e se mantém no ar durante 24 horas por dia. ${ }^{184}$

${ }^{184}$ TOMAZIELLO, Paulo Sergio e SANTANA, Ricardo A. F. Op. Cit. 2004. 
Segundo Galhardo, a emissora obteve vários nomes na época do grupo Piratininga; somente quando adquirida pelo senhor Francisco Silva Caldeira, segundo proprietário, é que passou a se chamar, primeiramente, Nova Alvorada e, posteriormente, Rádio Alvorada AM. Hoje ela faz parte do grupo Sistema Jornal de Rádio e TV, de propriedade de Orlando José Zovico.

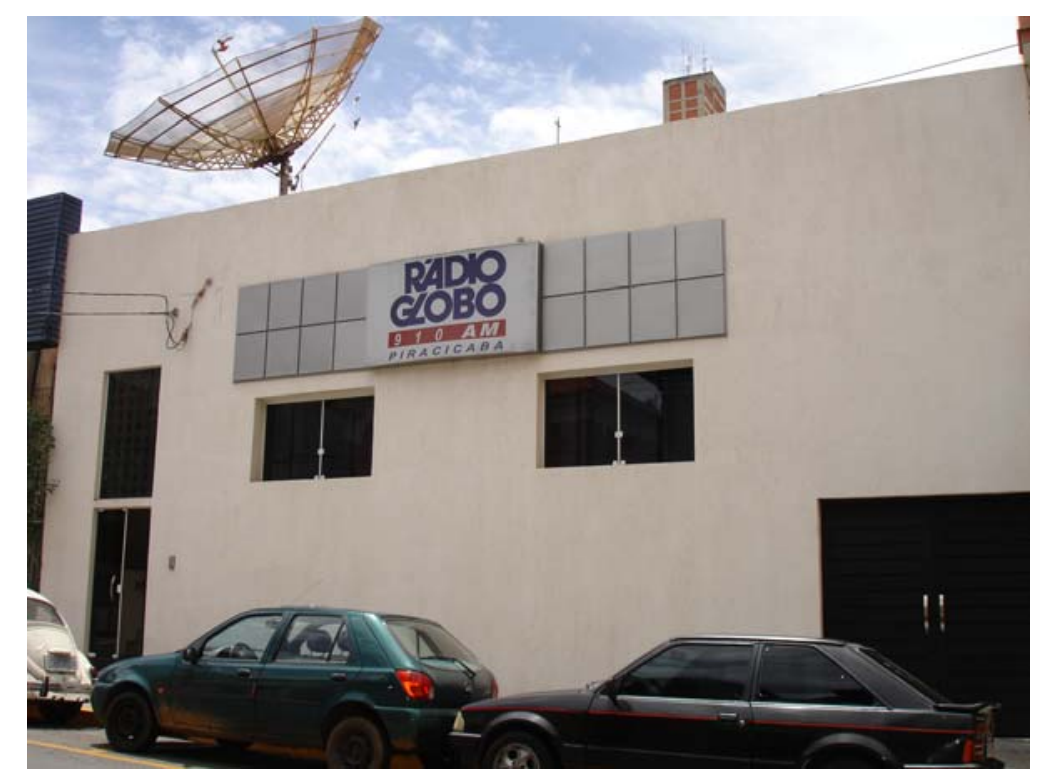

Fachada da Rádio Globo e Rádio 97 FM Universal

A programação da rádio era dividida em programas de esporte, jornalísticos e musicais, estes últimos destacando a música sertaneja.

O cururu também teve seu espaço na Rádio Alvorada, mas esporadicamente, pois quando os contratos com patrocinadores se expiravam, os programas permaneciam fora do ar até conseguirem novos patrocínios.

Em entrevista realizada no mês de janeiro de 2007, com Abel Bueno, exapresentador e cantador de cururu, constata-se que por aproximadamente 13 anos o cururueiro apresentou programas de cururu na Rádio Alvorada.

O programa chamava-se Viola e Repentes e era apresentado aos domingos com uma hora de duração; entretanto, em 2005, com a mudança da administração 
municipal, do PT para o PSDB, o contrato com a prefeitura, antes patrocinadora do programa, não foi renovado.

Em 6 de fevereiro de 2006, filiou-se a Rádio Globo Sat de São Paulo, passando a ser denominada Rádio Globo, operando há poucos meses na região.

De acordo com o site, a Rádio Globo Rio, primeira emissora do Sistema Globo de Rádio, nasceu em 2 de dezembro de 1944 e foi inaugurada pelo jornalista Roberto Marinho.

Em primeiro de maio de 1959, nasceu a Rádio Globo de São Paulo, primeiramente com o nome de Rádio Nacional, das Organizações Victor Costa e passou a se chamar Rádio Globo na segunda metade da década de 70. Em 2002, nasceu a Rádio Globo Minas, integrada à rede Rádio Globo Brasil. Começou a crescer a rede de afiliadas. ${ }^{185}$

Hoje, a Rádio Globo Brasil conta com três emissoras próprias - Rio, São Paulo e Belo Horizonte - e 20 afiliadas, espalhadas pelas cinco regiões do país. ${ }^{186}$

Segundo a revista Painel on-line a programação da emissora em rede nacional e regional inclui programas esportivos, de variedades e jornalísticos, além da programação local. ${ }^{187}$

A rádio opera em $910 \mathrm{MHz}$ e sua programação é de aproximadamente $80 \%$ retransmitida via satélite, restando apenas cinco horas para a programação local, que são divididas em três programas: Manhã da Globo, das 10 h00 às 13h00; Globo Cidade, das 17 h00 às 18 h00 e Globo Esportivo, das 18 h00 às 19 h00.

Para o diretor Paulo Eduardo Temple,

o ideal seria que toda emissora tivesse uma programação local, mas existem muitas dificuldades para isso. "Há uma legislação burra impedindo que o garoto de 18 anos trabalhe no rádio. Os salários do

\footnotetext{
${ }^{185}$ Site http://globoradio.globo.com/MusicCenter/0,,AFA0-4904,00.html. Acesso em: 23 nov. 2006.

${ }^{186}$ Site http://globoradio.globo.com/MusicCenter/0,,AFA0-4904,00.html. Acesso em: 23 nov. 2006.

187 Site http://www.unimep.br/fc/painelonline/painel52_01.htm. Acesso em: 23 nov. 2006. Acesso em: 23 nov. 2006.
} 
rádio, dos jornais e da televisão são muito pequenos e não competem com o mercado de trabalho. Isso acaba minando novos profissionais. Aí fica difícil montar uma equipe local, pela carência de profissionais", explica. ${ }^{188}$

\subsubsection{Rádio 97 FM Universal}

A Rádio 97 FM, sintonizada em $97,1 \mathrm{MHz}$, é mais uma emissora do grupo Sistema Jornal de Rádio e TV, de propriedade de Orlando José Zovico.

Inaugurada no começo da década de 1980 como Alvorada FM, substituiu seu nome em 1988 para 97 FM, mantendo a mesma programação baseada em músicas e boletins jornalísticos local.

A emissora passou por várias mudanças em pouco tempo: depois de 97 FM, ela passou a Transamérica FM, sendo repetidora da Rádio Transamérica São Paulo, com programação enviada via satélite, destinada a um público mais jovem, excluindo gêneros como sertanejo, pagode, samba e erudito, entre outros.

Terminado o contrato com a Rádio Transamérica, a emissora fez parceria com a Rádio Antena 1, também com programação via satélite, desta vez com o público-alvo diferente. Na programação estavam inseridas atrações com grande destaque para a MPB, mas contava também com boletins informativos e programas de músicas eruditas.

Vencido o contrato com a Antena 1, a rádio voltou com a programação local, novamente como $97 \mathrm{FM}$, desta vez com programas diferentes, sendo os de mais importância no estilo sertanejo, como o Programa $L H$, apresentado pelo radialista Luiz Hercoton, que ia ao ar das 4 h00 às 9 h00 e das 16 h00 às 19h00, e também com programetes de humor, como o Café com Bobagem e boletins informativos.

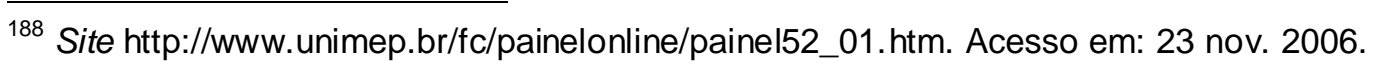


Em 2000, a Rádio 97 FM e toda sua estrutura foram arrendados à Igreja Universal do Reino de Deus, passando a transmitir parcialmente a Rede Aleluia de São Paulo. É dirigida pelo pastor Renato Lemos e sua grade de programação inclui jornalismo e músicas evangélicas.

\subsection{O cururu nas rádios de Piracicaba}

Conforme exposto anteriormente no capítulo I, alguns pesquisadores entendem que as culturas têm sofrido influência dos meios de comunicação de massa, fruto da modernização, ou seja, têm perdido suas características naturais, implicando de certa forma a sua destruição. Entretanto, muitas dessas culturas têm resistido ou se adaptado e, ao invés de se destruírem, passam por um processo de transformação.

As transformações também podem ser de origem econômica, política e/ou social, desembocando nessa nova sociedade, na qual até mesmo os meios de comunicação têm sofrido alterações em suas estruturas e funções para se adaptarem a esse novo modelo de desenvolvimento.

Tem-se o cururu, repente do interior paulista, como exemplo de uma cultura que sofreu e sofre transformações nos meios de comunicação, especialmente nas rádios piracicabanas, e em sua originalidade.

De acordo com as pesquisas documentais e entrevistas efetuadas com cururueiros, técnicos, programadores, locutores e proprietários das rádios de Piracicaba, elaboradas especificamente para este estudo, no que diz respeito à difusão do cururu neste meio de comunicação, percebe-se que no decorrer dos anos 
esta cultura tem perdido espaço nas programações das rádios locais, presente apenas em duas das rádios pesquisadas.

A primeira rádio pesquisada foi a Rádio Difusora AM, uma das primeiras rádios do Brasil. Atualmente, a Difusora AM não possui programa voltado para o cururu, mas constatou-se a existência de programas que no passado fizeram muito sucesso.

De acordo com a revista comemorativa de 70 anos da emissora, "a música raiz da cidade, o cururu, projetou-se para todo Brasil pelos microfones da Difusora, por meio de grandes divulgadores como Nhô Serra, Pedro Chiquito e Parafuso."189

Conforme Eduardo Escalante, "foi a partir de 1939 que o cururu foi para o rádio, (Rádio Difusora de Piracicaba - PRD-6), alargando sua propagação como legítima manifestação de determinados grupos sociais."190

Antonio Celso Ribeiro da Silva, atualmente o funcionário mais antigo da rádio, em entrevista para esta pesquisa, relata "me lembro dos programas de cururu nas épocas de 60 a 80, que eram apresentados por grandes cantadores como o Nhô Serra, o Parafuso, mas esses programas acabaram no começo dos anos 80 por questões comerciais".

Já a Rádio Educadora AM conta com programas de cururu desde sua inauguração, em 1967. Conforme seu proprietário, Jairo Mattos, estes sempre tiveram grande importância na programação, com datas e horários diversificados e apresentados por cururueiros como Pedro Chiquito, Abel Bueno, entre outros.

\footnotetext{
${ }^{189}$ PETROCELLI, Mauricio. Op. Cit.. p. 14.

190 ESCALANTE, Eduardo A.. Op. Cit..p. 127.
} 
Atualmente a emissora possui um programa com espaço para o cururu denominado Som da Terra, transmitido ao vivo todos os domingos das 10 h00 às 12h00, com apresentação de José Moacir Bombo e Adair Doniani, o Samaritano.

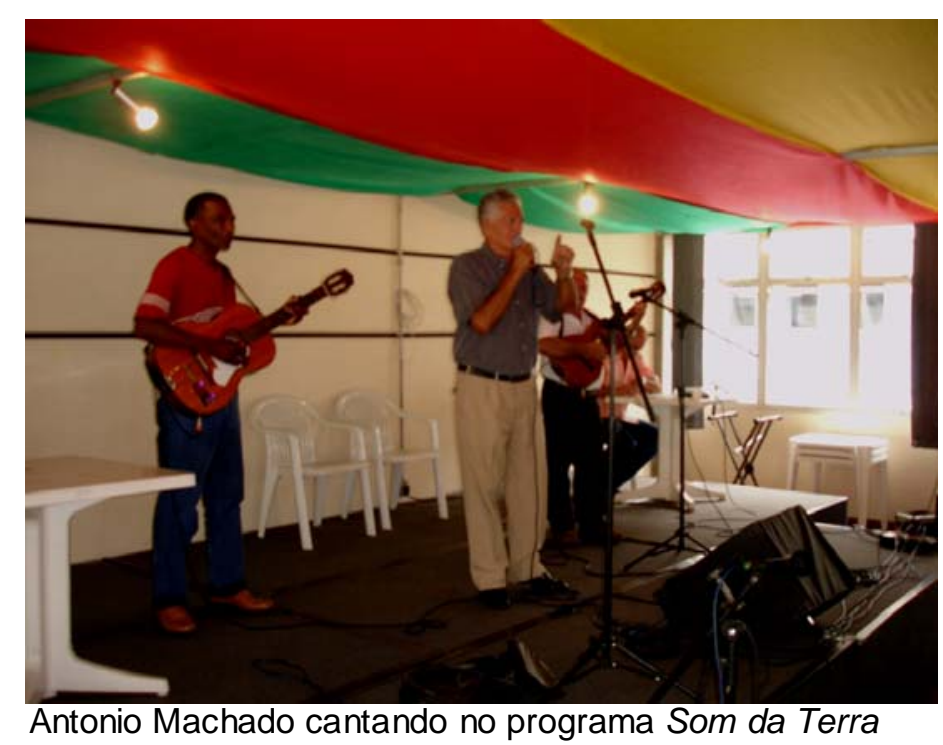

De acordo com Samaritano, este programa especificamente começou suas transmissões em 10 de maio de 1983, direto do SESC de Piracicaba, localizado na Rua Ipiranga, mas há 9 anos passou a ser realizado nas dependências do SESI, Iocalizado na Vila Industrial, em Piracicaba.

O programa é de auditório, como antigamente, com a presença de pessoas sentadas em cadeiras durante as apresentações enquanto é transmitido. A faixa de idade das pessoas que comparecem no local varia geralmente de 40 a 80 anos. 


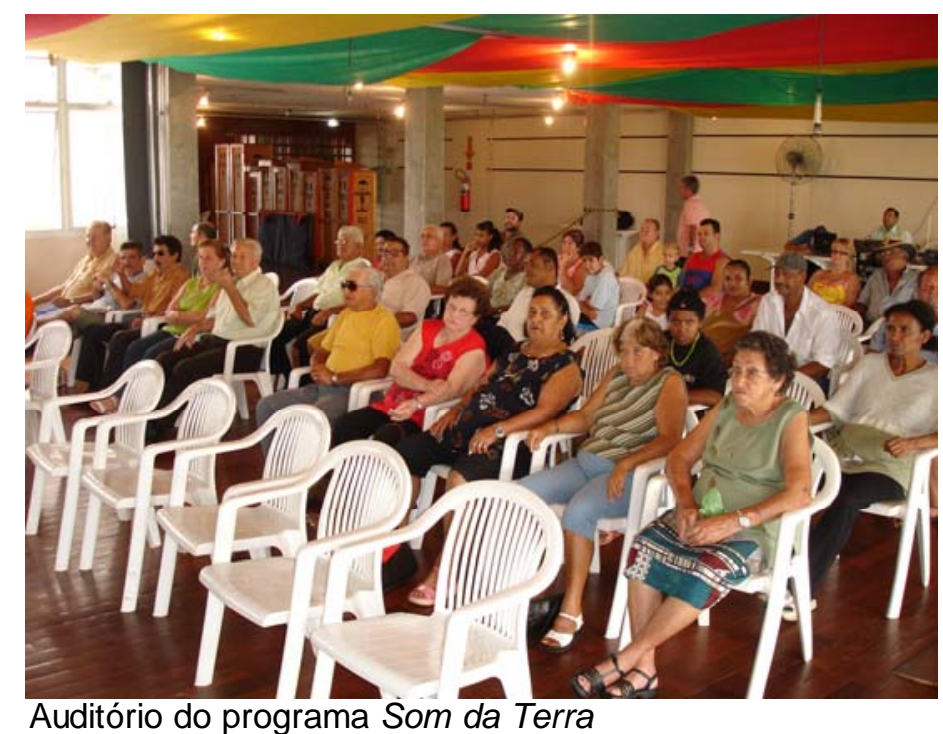

Vale salientar que o programa de duas horas é dividido entre o cururu e a música sertaneja ou moda raiz, com propagandas entre as apresentações, sendo a primeira hora dividida em dois blocos para a apresentação de quatro cururueiros, dois em cada bloco, e a segunda hora para quatro duplas sertanejas, duas em cada bloco. As propagandas entre os blocos são geralmente de agropecuárias, supermercados, lojas de roupas, lanchonetes e lojas de materiais de construção.

Quanto à idéia da inserção deste programa na emissora, Samaritano explica que o que os motivou foi ajudar as culturas piracicabanas e a preocupação em manter a tradição do cururu e da moda-de-viola na programação da rádio.

Outra rádio que também inclui o cururu em sua programação é a Educativa FM, única emissora pública e educativa da cidade.

A Educativa começou a transmitir o programa de cururu a partir de 1989, um ano após sua inauguração, enfatiza Moacir Siqueira, "apresentado pelo Parafuso, e depois dele por outros cururueiros".

De acordo com Tomaziello, em estudos sobre a rádio entre 1988 e 1992, a emissora possuía um programa intitulado Cururu e Repente na Terra da Gente. 
Programa de auditório, onde os artistas populares da cidade e região, ligados ao cururu e à moda de viola, se apresentavam ao vivo, cantando e tocando temas através de repentes e ritmos regionais. Era transmitido aos sábados à tarde, com início às $18 \mathrm{~h} 00$ e término às 20h00. Durante o tempo em que ficou no ar foi apresentado por Carlos Eduardo Gaiad, Xilmar Ulisses e Tarcísio Chiarinelli, e tinha a coordenação dos repentes feita por Pedro Chiquito. ${ }^{191}$

O programa somente parou de ser transmitido entre os anos de 1993 e 1996, durante o governo do prefeito Antonio Carlos Mendes Thame, por motivos desconhecidos, retomando as suas retransmissões em 1997, na gestão do prefeito Humberto de Campos.

Hoje, o programa chama-se Nossa Terra, Nossa Gente, apresentado pelo cururueiro Moacir Siqueira, e vai ao ar todos os domingos no horário das 6 h00 às 8h00, sendo uma hora de cururu e uma hora de música sertaneja-raiz.

No início, o programa era ao vivo, com apresentações transmitidas diretamente da Rua do Porto, da Praça do Semae ou de outros lugares; no último ano do mandato do PT, em 2004, as apresentações passaram a ser gravadas e, com a transição para o governo do PSDB, em 2005, as apresentações se acabaram, com gravação apenas do apresentador, sendo a seleção de músicas retiradas de CDs.

Segundo Moacir Siqueira, hoje o programa é gravado sempre na quarta-feira que antecede o domingo em que o programa vai ao ar. No programa não há apresentação de cururueiros; a programação é feita com CDs com gravações de cururu do passado e também com gravações atuais, escolhidas pelo próprio Moacir e pela equipe de programação. "Antigamente, autorizava nói grava de segunda-feira à noite, mas o novo prefeito não quis mais pagá hora extra para o técnico de som ficá com nóis pra gravá. Nóis ia graciosamente cantá, mas ele não aceitô pagá", enfatiza Moacir Siqueira.

${ }^{191}$ TOMAZIELLO, Paulo Sergio e SANTANA, Ricardo A. F. Op. Cit. 2004. 
O programa é dividido em cinco blocos de vinte minutos; em cada bloco tocam duas duplas sertanejas e dois cantadores de cururu. Entre os blocos são inseridos os apoios culturais.

Ultimamente, Moacir Siqueira, cururueiros e membros da equipe têm procurado parcerias para voltar a transmitir o programa ao vivo, direto de algum bairro da cidade, como programa de auditório para o público assistir e participar, mas até agora não obtiveram sucesso.

O cururu também teve seus dias de glória na antiga Rádio Alvorada AM, hoje Rádio Globo.

Tomando por base nossas pesquisas, pouco se sabe sobre datas e detalhes dos programas da emissora; o que se sabe é que desde o início, ainda com nome de Voz Agrícola, na década de 1960, o programa de cururu era considerado um dos principais programas da emissora, apresentado também por cantadores de cururu da época.

Abel Bueno relata que foi apresentador de programas de cururu durante 13 anos na Alvorada AM; segundo ele, "na década de 70, os programas reinavam na programação, e eram bem disputados por empresas que queriam patrocinar os programas, mas com o tempo, as músicas novas foram surgindo, as empresas querendo patrocinar outros programas e a rádio foi diminuindo o espaço para o cururu".

O último programa de cururu que existiu na Rádio Alvorada AM, Violas e Repentes, também apresentado por Abel Bueno, saiu do ar em 2005, tendo em vista que seu patrocinador, a prefeitura do município, que até 2004 foi governada pelo PT, com a transição de governo para o PSDB, em 2005, não renovou o contrato com o 
programa para mantê-lo no ar, deixando assim a grade sem programas sobre a cultura local.

As rádios de Piracicaba que não possuem e não abriram espaço para o cururu em suas programações são a Difusora FM, 97 FM universal (Alvorada FM) e Jovem Pan (Educadora FM).

A Difusora FM, segundo José Celso, "não inclui o cururu na programação, pois o público-alvo da FM não pede cururu, a programação da rádio é voltada para as músicas atuais, que estão fazendo sucesso no momento".

Já a 97 FM Universal, que hoje pertence à Igreja Universal do Reino de Deus, não incluiu o cururu na programação, segundo Galhardo, porque ela é voltada exclusivamente para o público evangélico, apenas com jornalismo e músicas evangélicas.

E, por fim, a Jovem Pan FM, antiga Educadora FM, que, por possuir um programa na Educadora AM e também por receber uma programação via satélite, voltada totalmente para o público jovem, não abre espaço para o cururu, tendo que seguir algumas regras de programação, o que pode levar a ser considerado violação e até perda do direito de retransmissão.

Dessa forma, pode-se concluir que, dentre as sete emissoras de rádio existentes em Piracicaba, três AM`s e quatro FM`s, o cururu só aparece em apenas duas, sendo elas a Educadora AM, com o programa Som da Terra, que dispõe de uma hora para o cururu, e a Educativa FM, também disponibilizando uma hora para o cururu no programa Nossa Terra, Nossa Gente, ambos tentando sobreviver diante dos impactos da modemização que vem acontecendo nas emissoras de rádio da cidade. 
V - CONSIDERAÇÕES FINAIS 


\section{Considerações finais}

Eu acho que não agüento nem mais um ano cantando cururu, nem ficar tentando achar patrocínio pra tentar manter o cururu na rádio. Cada dia que passa o espaço vai acabando, as empresas não querem pagar o valor de um programa de rádio, e é muito caro para os cururueiros. Hoje em dia tem que pagar pra cantá, pra você ir em algum lugar se apresentá, tem que pagar a condução e o violeiro. Tá difícil, eu to querendo me aposentá do cururu.

Abel Bueno, cantador de cururu há 54 anos.

Essa frase em forma de desabafo, referindo-se à dificuldade dos cururueiros de continuar cantando cururu e de poder divulgá-lo nos meios de comunicação, principalmente no rádio, é um bom motivo para iniciar as considerações finais sobre este trabalho, sem deixar de lado o fato de que o rádio vem sofrendo modificações ao longo dos anos, fruto da modernização.

Conforme referência no capítulo 1 , existe o perigo de que os instrumentos de comunicação de massa, com os avanços tecnológicos, deterioram os gostos estéticos, os padrões culturais populares e, conseqüentemente, a cultura popular.

Para Oliveira,

a cultura popular é aquela criada pelo povo e apoiada numa concepção de mundo específica e tradicional para seus criadores. Ela existe e se mantém através de manifestações populares de seus produtos culturais que só é possível através de ainda que mínimo um suporte organizacional, financeiro e comunicacional. ${ }^{192}$

O objeto deste trabalho, a difusão do cururu nas rádios de Piracicaba, buscou compreender o cururu e a participação das emissoras de rádio de Piracicaba na difusão desta cultura local.

\footnotetext{
${ }^{192}$ OLIVEIRA, Maria José. Op. Cit.. 2003.
} 
Piracicaba é uma cidade com uma rica história, construída a partir do rio homônimo que corta a cidade, com inúmeras manifestações populares que são motivo de orgulho para seus habitantes, pois estas atraem pessoas de toda a região e até de grandes centros para apreciá-las ou até mesmo estudá-las. Entre estas manifestações, destacam-se a Festa de São João de Tupi, Festa do Divino Espírito Santo, a Catira, o Cateretê e o Cururu.

Essas manifestações culturais organizadas por grupos sociais são consideradas muito importantes para o povo piracicabano, que delas participa com orgulho, pois resgatam a sua identidade e fortalecem o imaginário cultural.

Por outro lado, tais manifestações estão perdendo espaço nos meios de comunicação da cidade, deixando de ser divulgadas e, assim, criando novas características para chamar a atenção das mídias de massa.

Alguns mantedores do cururu, ao sentirem que esta cultura está perdendo seu espaço nas rádios de Piracicaba, começam a criar novas formas de desafios para poder resistir aos poucos espaços que lhes conferem. Mas algumas modificações são reprovadas por alguns cururueiros, que lutam para manter o cururu mais próximo de sua originalidade.

Podem-se notar algumas outras transformações no cururu no decorrer dos anos, como a transferência das apresentações diante de um altar para o palco, praças públicas e bares, como também a influência do funk e a introdução de palavras obscenas nas rimas.

A pesquisa com os cururueiros e representantes das rádios da cidade denunciou uma falta de abertura ao cururu por parte das emissoras, embora existam dois programas em duas rádios distintas, os quais divulgam esta cultura em sua programação.

Das sete emissoras existentes em Piracicaba, apenas a Educadora AM e a Educativa FM oferecem programas de cururu, dividindo o espaço com a música sertaneja, restando apenas quarenta minutos para a divulgação do cururu em cada programa, sendo que na 
Educativa, transmitido no horário das 6 h00 de domingo, tempo muito pequeno para uma cultura atuante como o cururu na cidade.

De acordo com José Carlos Fortinove, que canta há 12 anos, um fator que dificulta a divulgação do cururu é que um horário na Rádio Difusora AM, com 1 hora de duração, uma vez por semana, custa em média de $\mathrm{R} \$ 1.500,00$ a $\mathrm{R} \$ 2.000,00$.

Outro fator exposto por Abel Bueno é o fato de que "hoje as rádios, nos grandes eventos, se aproveitam do cururu, colocando um locutor da emissora para apresentar o show, como se rádio estivesse cobrindo todas as despesas, e é mentira, elas só querem aparecer".

Segundo os representantes das rádios que não possuem programas de cururu, hoje não vale a pena inserir este tipo de programa, pois não existe interesse de patrocinadores para a sua viabilização, não trazendo retorno financeiro para as rádios. No entanto, estes resultados podem representar um poder ameaçador para as manifestações culturais tradicionais de Piracicaba, tendo em vista que as rádios locais exercem influência nos hábitos, nas crenças e estilo de vida dos ouvintes, podendo fomentar o consumo dos mercados mundiais.

É inegável que o cururu tenha espaço na programação de rádios da cidade, ainda que muito pequeno, e que o papel que as emissoras desempenham nas manifestações culturais é reconhecido pelos cururueiros, mas, por se tratar de uma cidade que é considerada a capital do cururu, espera-se mais por parte das rádios locais.

As rádios deveriam procurar interagir com os grupos sociais organizadores das manifestações populares e com eles articular ações para difusão da cultura local, divulgando mais os assuntos dos movimentos coletivos e de grupos e segmentos da cidade, dando sua contribuição como veículo de comunicação. 
Deveriam também procurar saber por quais razões os ouvintes e patrocinadores não têm participação mais efetiva na programação voltada para a cultura local, e tentar localizar um meio para que essa participação aconteça.

Abel Bueno relata que até hoje procura parceria com as rádios ou com a prefeitura para poder fazer uma oficina de cururu, para ensinar a história do cururu e também explicar sobre as rimas, os versos e a toada de cururu. Segundo o cururueiro, um dos principais problemas da população, e até de quem canta cururu hoje em dia, é a falta de conhecimento sobre a história do cururu, como surgiu e como era antigamente. Para ele, se houver acesso mais fácil a este tipo de informação, talvez os cantadores de hoje pudessem melhorar o seu jeito de cantar, não distorcendo a história nem recorrendo a palavras obscenas nos desafios, além do que poderia despertar maior interesse na população mais jovem.

Uma sugestão seria inserir pequenos boletins sobre a história do cururu e desafios de cururu na programação dos musicais sertanejos, por exemplo, podendo ser apresentado um desafio antes e outro depois, ou um desafio no meio do programa.

Um exemplo disso é uma observação de Oliven, no livro Estado e Cultura no Brasil, segundo a qual

no começo da década de sessenta o regionalismo, especialmente o nordestino, era visto como um dos temas mais candentes da nacionalidade, o Estado e os meios de comunicação, se apropriam desta temática através de uma manipulação que a transforma em assunto trivial e anódino, criando programas que procuram valorizar "aquilo que é nosso". Em programas radiofônicos como o Minerva em Ação Cultural e Domingo Mobral, isto significa não só divulgar músicas como, por exemplo, os ternos de reis de alguma região brasileira como algo que precisa ser lembrado e valorizado, mas também no mesmo programa atender a solicitação de um ouvinte que deseja ouvir uma música de Roberto Carlos. Pois nesta proposta o Brasil seria justamente esta soma colorida e tropical de manifestações regionais (apresentadas de um modo museológico e tendendo para o exótico e turístico) que precisam ser conhecidas e valorizadas junto com as criações produzidas nos grandes centros e que são divulgadas nas mais distantes áreas do país como forma de modernidade e integração. ${ }^{193}$

\footnotetext{
${ }^{193}$ OLIVEN, Ruben George apud MICELI, Sérgio. Op. Cit.. p. 51.
} 
Lembrando também as palavras de Celso Furtado, "é certo que um maior acesso a bens culturais melhora a qualidade da vida dos membros de uma coletividade. Mas, se fomentado indiscriminadamente, pode frustrar formas de criatividade e descaracterizar a cultura de um povo."194

Nota-se, porém, que doravante muito pode ser feito para que as rádios de Piracicaba se tornem agentes ativos na divulgação das culturas locais, atuando mais nos processos comunicacionais da cidade e, conseqüentemente, preservando suas tradições.

${ }^{194}$ FURTADO, Celso. Op. Cit.. p. 32. 
VI - REFERÊNCIAS BIBLIOGRÁFICAS 


\section{Referências Bibliográficas}

ADORNO, Theodor. A indústria cultural. In: CONH, Gabriel (org.). Comunicação e indústria cultural. São Paulo: EDUSP, 1971. p. 287-295.

BAUDRILLARD, Jean. Simulacros e Simulação. Lisboa: Relógio D`Água, 1991.

BOSI, Alfredo. Plural, mas não caótico. In: BOSI, Alfredo. Cultura brasileira. São Paulo: Ática, 1987.

CHAUÍ, Marilena. Conformismo e resistência - aspectos da cultura popular no Brasil. São Paulo: Brasiliense, 1989.

CUCHE, Denys. A noção de cultura nas ciências sociais. 2. ed. Bauru: EDUSC, 2002.

CARRADORE, Hugo Pedro. Retrato das Tradições Piracicabanas (história e folclore). 2. ed. Piracicaba: Instituto Histórico e Geográfico de Piracicaba, 1998.

CASTILHO, Dinah e CASTILHO, Wenceslau. Raízes caipiras de Piracicaba na era da globalização - o cururu, a catira e a moda-de-viola. Piracicaba: C. N. Editora, 2005.

ELIAS NETO, Cecílio. Almanaque 2000: Memorial de Piracicaba - Século XX. Piracicaba/SP: IGHP; Jornal de Piracicaba; UNIMEP, 2000.

ERCOLIN, Giselda (Org). Piracicaba: A noiva da Colina. São Paulo: Noovha América, 2005. (Série conto, canto e encanto com a minha história).

ESCALANTE, Eduardo A. A música no cururu do Médio Tietê paulista. Dissertação (Mestrado em Artes). Universidade de São Paulo. São Paulo - 1986.

FERRAZ, Mário Sampaio. Piracicaba e sua Escola Agrícola. Bruxelas: V. Verteneuil \& Desmet, 1911.

FERREIRA, A. Buarque de Holanda. Dicionário Brasileiro da Língua Portuguesa. São Paulo: Nova Fronteira,1975. 1091p.

FURTADO, Celso. Cultura e desenvolvimento em época de crise. Rio de Janeiro: Paz e Terra, 1984.

GARCIA CANCLINI, Nestor y RONCAGLIOLI, Rafael. Cultura Transnacional y Culturas Populares. Lima: Ipal, 1998.

GIL, Antonio Carlos. Métodos e técnicas de pesquisa. 5. ed. - São Paulo: Atlas, 1999.

GUIDOTTI, José L. Navegando pelo Piracicaba. Piracicaba: Shekinah, 1992. 
GUERRINI, Leandro. História de Piracicaba (Noiva da Colina), antes de sua Fundação, In: BARROS, Antônio da Costa. Piracicaba - Noiva da Colina. Piracicaba: Aloisi, 1975.

HALL, Stuart. A identidade cultural na pós-modernidade. Rio de Janeiro: DP\&A, 1999.

IANNI, Octavio. Imperialismo e cultura. 3. ed. Petrópolis: Vozes, 1979.

IKEDA, Alberto T. - Cururu: resistência e adaptação de uma modalidade musical da cultura tradicional paulista. São Paulo: ARTEunesp,1990.

KRAHENBUHL, Hélio (Org.). Roteiro do Rio Piracicaba. Almanaque de Piracicaba. Piracicaba: João Fonseca, 1955.

LARAIA, Roque de Barros. Cultura: um conceito antropológico. 14. ed.. Rio de Janeiro: Jorge Zahar, 2001.

LIMA, Luiz Costa. (Sel.). Teoria da cultura de massa. São Paulo: Paz e Terra, 2000.

LUYTEN, Joseph M. Desafio e repentismo do caipira de São Paulo. In: Bosi, Alfredo. Cultura Brasileira temas e situações. São Paulo: Ática, 2002.

MICELI, Sergio (org). Estado e cultura no Brasil. São Paulo: IDESP, 1984.

MICHAELIS. Moderno Dicionário de Língua Portuguesa. São Paulo: Companhia Melhoramentos, 1998, 974p..

MOURÃO, J. O. Fusaro. Piracicaba 2010 - realizando o futuro. Piracicaba, SP: Júlio Olímpio Fusaro Mourão, 2001.

NEGRI, Barjas. A concentração/desconcentração industrial em São Paulo. Doutorado. Tese (Doutorado). Instituto de Filosofia e Ciências Humanas-IFCH Universidade de Campinas/UNICAMP, Campinas, 1996.

NEME, Mário. A História da Fundação de Piracicaba. Piracicaba/SP: Instituto Histórico e Geográfico de Piracicaba, 1934.

NEPTUNE, Nordahl Christian. Elias dos bonecos. Campinas/SP: [s.n], 2003.

ORTIZ, Renato. Cultura Brasileira e Identidade Nacional. São Paulo: Cortez, 2001.

PERECIN. Marly T. G. Três Momentos Históricos da Fundação de Piracicaba. Prefeitura Municipal de Piracicaba, 1989.

PERES, Maria Thereza Miguel. Idealizações e tensões na construção de Piracicaba Moderna(1950-1960). Tese de Doutorado, Universidade de São Paulo/USP, Faculdade de Filosofia, Literatura e Ciências Humanas, FFLCH, São Paulo, 1997. 
PIRACICABA: Passado e Presente. Prefeitura Municipal de Piracicaba - São Paulo, 1988

SANTOS, Milton. Por uma Outra Globalização - do pensamento único à consciência universal. São Paulo: Record, 2002.

Setenta anos da Rádio Difusora, Piracicaba/SP: Podium Editora e Marketing S/C LTDA, dez. 2003. Edição especial.

SODRÉ, Nelson Werneck. Síntese de história da cultura brasileira. 11. ed. Rio de Janeiro: Civiliz Brasil.

STRINATI, Dominic. Cultura popular: uma introdução. 1.ed.. São Paulo: Hedra, 1999.

TITIEV, Mischa. Introdução à antropologia cultural. 9. ed. Lisboa: Fundação Calouste Gulbenkian, 2002.

TOMAZIELLO, Paulo Sergio e SANTANA, Ricardo A. F. Radiodifusão, cultura e participação popular: a valorização do local pela Rádio FM Municipal de Piracicaba. In: II Encontro Nacional da Rede Alfredo de Carvalho -Trabalho apresentado ao GT 09 - História da Mídia Sonora, 2004.

TORRES, Maria C.T.M. Aspectos da expansão urbana de Piracicaba nos primeiros anos do Século XX. Revista do Instituto Histórico e Geográfico de Piracicaba, Piracicaba, SP, ano 1, n. 1, p. 47-48, Dez. 1991.

TYLOR, Edward B. La Civilization primitive. Paris: Reindwald, 1876-1878, 2v.

WARNIER, Jean Pierre. Mundialização da Cultura. EDUSC, 2000.

V Congresso Latino Americano de Ciências da Comunicação ALAIC, 2000, Chile. BENJAMIN, Roberto. Cachaça e rapadura, símbolos da comunicação popular em Areia-Paraíba - Brasil.

V Congresso Latino Americano de Ciências da Comunicação ALAIC, 2000, Chile. BRANCO, Samantha Castelo. Cultura popular $X$ cultura de massa: onde Judas não perdeu as botas Brasil.

XXVI Congresso Brasileiro de Ciências da Comunicação OLIVEIRA, Maria José. Benditos sejam: resgate histórico sobre os cordelistas malditos de Juazeiro do Norte. Anais. Belo Horizonte: Intercom, 2003.

http://globoradio.globo.com/MusicCenter/0,,AFA0-4904,00.html

http://www.unimep.br/fc/painelonline/painel52_01.htm 
http://www.unimep.br/fc/painelonline/painel52_01.htm

http://www.unimep.br/fc/cururu/server/oqecuru.htm

http://www.brasilnoar.com.br/MT/mt_danças_orig_cururu.asp

http://www.brasilnoar.com.br/MT/est_mt_dan\%E7as_orig_cururu.htm

http://www.glogernet.pro.br/glogernet/cultura\&lazer/folclore/danca\%20populares/dan ca_cururu.htm

http://www.ipplap.com.br 
VII - APÊNDICES 


\section{APÊNDICE 1.}

\section{QUESTIONÁRIO PARA OS CANTADORES (ROTEIRO NÃO ESTRUTURADO)}

1. Nome completo e idade?

2. Como começou? Herdou da família ou qual foi a influência?

3. Há quanto tempo canta?

4. Participa de eventos?

5. Participa ou participou de programas de rádio? Qual?

6. Acha que o cururu é conhecido pela população de Piracicaba?

7. A quantidade de cantadores de hoje é a mesma do passado? E o que influenciou para esse fator?

8. O que toca mais, repente ou desafio? E o que se destaca mais?

9. Já gravou algum CD de cururu? Qual?

10. O que falta para o cururu em Piracicaba?

11. Você acha que o cururu é bem divulgado em Piracicaba? Por quê?

12. O que as rádios poderiam fazer para divulgar o cururu?

13. Qual o nome e a idade do cantador de cururu mais novo que você conhece? 


\section{APÊNDICE 2.}

\section{QUESTIONÁRIO PARA AS RÁDIOS (ROTEIRO NÃO ESTRUTURADO)}

Nome completo e idade?

1) Nome da rádio?

2) Amplitude modulada ( $\mathrm{AM}$ ) ou freqüência modulada ( $F M)$ ?

4) Existe alguma programação voltada ao cururu?

5) Se existe, desde quando? Qual o dia, horário e duração?

6) Se não existe, já existiu? Por que acabou?

7) Quem é o locutor?

8) Como decidiram inserir esse programa?

9) Qual a audiência do programa? Como é calculada?

10) Existe participação do público? Qual é a média de idade?

11) A rádio realiza algum evento voltado ao cururu?

12) O formato do programa de cururu é o mesmo dos demais? 


\section{APÊNDICE 3 - Entrevistas cururueiros}

\section{LUIZ VALÉRIO}

Meu nome é Luiz Valério e tenho 67 anos nas costas.

Comecei a cantar por inclinação e também tive o apoio da família, já faz 18 anos que eu canto, com muita satisfação.

Eu sempre participei de eventos, desde que comecei a cantá, hoje eu participo mais das rodas em praça, que a gente se junta e canta.

Eu já fui em todas as rádios de Piracicaba e também na TV Beira-Rio, mas não me pergunte as datas porque não sei. Ah! e também fui em rádios da região, na TV de Sorocaba e na TV de Santa Bárbara.

O cururu, quando é bem cantado, é bem-aceito mais pelo público de meia-idade em diante, os jovens num conhece muito, é mais os velhos que gosta.

A quantidade de cantador é mais ou menos igual, mas devido à evolução moderna, essa influência estrangêra e evolução tecnológica, houve muita infiltração estrangêra, a juventude deixo de aprecia o nosso cururu. Bom, na verdade, muitos cantador não se prepara para serem bons cururueiros como antes.

O repente tem sido mais cantado, hoje é difícil quem cante na bíblia.

Já gravei vários CD pra gosto familiar e pros amigo, o último CD foi de desafio em Sorocaba, na praça.

O que falta pro cururu hoje é mais programa de rádio, apoio financeiro e os cantadô se prepara mais, pará com panelinha entre certos cantadô também.

O cururu não é bem divulgado não. Quando tinha o apoio da prefeitura na FM era mais divulgado, hoje é uma repetição dominguêra por falta de apoio.

O que falta as rádio fazê é facilitar a programação de cururu e fica fácil arrumá apoio financeiro, porque o programa de rádio realmente divulga o cururu.

Eu conheço alguns com uns quarenta e tantos anos, mas a gente não nota uma melhoria nas apresentação, uma evolução na qualidade.

\section{MAURO BORTOLETO}

Meu nome completo é Mauro Bortoleto, vou completar 54 anos este ano.

Eu comecei a cantá cururu porque sempre vi o pessoal cantá, sempre gostei e fui me interessando, fui fazendo um versinho aqui, outro ali e hoje eu canto. Faz pouco tempo que eu canto, faz uns 3 anos mais ou menos, num faz muito tempo não. 
De eventos, cantando, eu participo mais nas praças mesmo, às vezes chamam a gente pra cantá em alguma festa de bairro, mas é muito difícil o mais mesmo é cantar no programa da Educadora ou nas praças mesmo.

Óia, programa de rádio eu participo pouco por que quase num tem. O da Educativa é gravado, com coisas antigas e bem cedo, eu participei mesmo é o do Som da Terra na Educadora, quem apresenta é o Moacir Bombo, e o outro não é aqui da cidade, pode fala? É o do Rancho do Edgar em Santa Bárbara.

Pela população de Pira até que é, mas o pessoal da região num conhece não, os de Pira conhece porque sempre tem alguém na Rua do Porto, ou em algum bairro com viola na mão e um cantador, mas poderia ser melhor, mais conhecido.

A quantidade de cantador é a mesma coisa, num tem mais nem menos, o que tem é cantador fajuto hoje em dia, canta de qualquer jeito, num sabe cantá direito. Nós tivemo grandes nomes no cururu e ta acabando os cantadô bão. O que aconteceu é que pra se mostrá, pra aparecê, os cantadô tão apelando, falando palavrão, fazendo panelinha. É isso, é uma farta de respeito.

Hoje o que canta mais é o desafio, também canta o repente, mais é mais difícil, nas praça é mais desafio, é um contra o outro.

Óia, gravá CD num gravei não, gravei foi um DVD que tinha o nome de Azulão e seus convidado, num é pra TV não, é mais pra distribuí entre os amigos e a família.

Pro cururu fica bem em Piracicaba, falta ele ser mais divulgado, falta incentivo, às vez a gente tenta conversa com alguém mais conhecido como vereador ou algum político mas eles só promete, o cururu tá ficando esquecido, só nas festa lembram de nóis.

Nas rádio o que falta é fazer mais programa de cururu, você veja só, de programa nóis tem o do Moacir na Educadora que dá espaço mais é só uns 30 minuto e o da Educativa que também é pouco tempo e é gravado, num aparece cururu novo. Precisava mais espaço pro cururu, ele é a paixão dessa terra aqui e as rádio num tão nem aí.

O cantadô mais novo que eu conheço é um muleque de 47 anos, o Dorival, ahahaha, eu num conheço mais ninguém mais novo que eu acho. É difícil encontrá, tem uns que começa a cantá e depois para logo em seguida. Acho que porque num dá dinheiro.

\section{ANTONIO MACHADO}

Meu nome é Antonio Machado, também conhecido como Rouxinol Capivariano, sou nascido em 25 do 7 de 1933, faça as conta aí, eu tenho 73 anos. 
Aprendi a cantá de vontade própria, comecei a observa os amigo e fui começando devagarinho, hoje eu canto quarqué assunto, você escutou, eu tava cantando a respeito das droga hoje.

Nessa brincadeira eu to cantando há 40 anos, tive um problema de saúde mas to aí de volta,cantando de novo.

Os eventos que participo são mais os culturais em Piracicaba, as vez em outra cidade, mas aí você tem que pagá pra ir, então fica difícil, malemá eles dão um lanche pro cantadô e pro tocador. Mas é mais em Piracicaba nas praça, na Rua do Porto, Largo dos Pescadores.

Programa de rádio é muito pouco, eu participei dos programa da Rádio Educadora e pouco da Educativa aqui em Pira e dos programa da Rádio Cacique de Capivari e a Porto Felizense, em Poto Feliz.

O conhecimento da população em relação ao cururu é pouco, Piracicaba ainda conhece um pouco, mas ta acabando aquele negócio de todos conhecerem como era antigamente, hoje é só os mais véio que conhece e que comparece nos lugar que a gente canta, a meninada num ta nem aí pro cururu.

A quantidade é a mesma acho, sempre tem cantadô, mas num é mesma coisa do tempo de Nhô Serra, Pedro Chiquito, Parafuso, a coisa mudo. O que ajuda é a música sertaneja, o pessoal escuta e qué cantá também aí vai aparecendo um aqui, outro ali, mas num é mesma coisa.

O que toca mais é o repente, pelo menos eu escuto mais canto mais repente, o pessoal confunde muito com a cana-verde, mais no meu ver é mais o repente que os cantadô canta mais.

CD acho que gravei um, mas agora tô com dois DVD, é mais pra distribuí pro pessoal, não é pra vende, nóis até tentamo achar alguém pra bancá o DVD pra vendê, mas o pessoal num quis.

O que falta pro cururu em Piracicaba é apoio cultural, patrocínio, tá difícil hoje, falta mais reconhecimento das autoridade, e se continuar assim vai fica pior, hoje às vez você tem que pagá pra cantá, tem que pagá violero e pra ir até o lugar, antes era diferente, o pessoal fazia questão de ajuda os cururueiro. Hoje só vem ajuda, se vier em época de eleição e olhe lá.

As rádios podia dar mais espaço para programas de cururu, hoje só tem dois programa e um ta com dificuldade, ta perdendo espaço, pergunta pro Moacir, eles contaram verba do programa da Educativa, só tão fazendo programa gravado e vai ficando cada vez mais difícil.

O cantadô mais novo, é ... bom, tem um rapaiz que canta, ele é novo, deve de tê uns 34 anos, é o Beybe, mas num sei se pode falar que ele é cantadô, porque ele canta um pouco depois some, para de cantar uns ano e depois quando se encontra com o pessoal ele canta um versinho e outro, mais só quando encontra o pessoal. 


\section{LUIZ DAS NEVES}

Eu me chamo Luiz das Neves e tenho 65 anos de idade, nascido em 12 do 10 de 1940. Tá bom ou qué mais?

Eu comecei vendo os amigo, escurtando na rádio, escurtando os grande cantadô.

Eu comecei a cantá há uns 35 anos atrás, é, é isso, eu canto há 35 anos.

De evento só participo no bar, num é bebendo não, é cantando, eu num participo em outros lugar não, é difícil, nas praça é de domingo e de domingo eu fico com a família.

Bom de programa de rádio eu participo da Educadora, quando o pessoal lá chama pra cantá, mas de rádio é só.

O cururu só é reconhecido pelos mais antigo, e também só em Piracicaba, esses dia eu tava em Americana, que é aqui perto e ninguém conhecia, é só em Piracicaba mesmo e tá acabando o interesse pelo cururu.

A quantidade de cantadô é igual, se tivé um pouco menos, mas é pouca coisa.

Que eu escuto que toca mais é o repente, as vez o pessoal mistura, mas é o repente que escuto mais.

Não, eu nunca gravei CD, nunca fui atrás pra vê de gravá.

Falta divulgação e ambiente pra toca, porque a gente toca mais em bar e praça pública, precisava de uns lugar mais chique pra cantá.

Se o cururu é divulgado?... mais ou menos, mas pra população em geral num é não.

As rádio podia fazer mais pograma e mais evento de cururu. Aí sim ia ficá bom.

Íche, o mais novo que eu conheço é aquele ali ó, que meninão, é o Bortoleto, ele tem uns 45, 50 anos.

\section{ABEL BUENO}

Bom, o nome é fácil, difícil é a idade, vamo lá. Meu nome é Abel da Silva Bueno e tenho 73 ano.

Eu comecei a cantá cedo, todos da minha família cantavam, era meu avô, meu pai, meu irmão Nhô Serra, até minha irmã cantava, é tradição de família mesmo, veio do berço, e até hoje nós tamo aí cantando, tentando sobrevivê, mais tamo aí.

Quanto tempo eu canto? iiiihhh! Faz tempo viu, faz exatamente 54 anos com muito orgulho. Hoje já não canto tanto quanto cantava antigamente, mas vamo levando. 
De evento eu participo de missas, eventos culturais aqui na cidade e também muito fora, hoje a gente tem que exportá cultura e importa cultura, aqui em Piracicaba tá tão difícil que a gente tem que se virá por aí.

Fiz programa 30 anos em rádio, 13 anos foi só na Alvorada, com o programa que chamava Violas e Repente, todo domingo durante uma hora rodava cururu, o programa durou até o final de 2004 começo de 2005, acabou com a mudança de prefeito, que cortô a verba, a prefeitura que patrocinava o programa.

Antes era mais fácil fazer programa, bastante gente queria patrociná, na década de 70, os programas reinavam na programação, e eram bem disputados por empresas que queriam patrocinar os programas, mas com o tempo, as músicas novas foram surgindo, as empresas querendo patrocinar outros programas e a rádio foi diminuindo o espaço para o cururu.

Meu irmão tinha programa na Difusora, e eu ajudava, apresentava também, isso foi em 1954 se não me engano, a Difusora era a PRD6, e também teve na Educadora, mas não lembro data, nada.

A quantidade de cantador tem até mais, com vontade, mas não tem a qualidade sadia, tá tudo muito jocoso, pornográfico. Antes cantava no altar louvando o santo hoje está difícil achar cururueiro que cante, contando a história de Jesus por exemplo, hoje o pessoal só qué falá besteira, é um xingando o outro, sem respeito, coisa que não existia antigamente, não se admitia isso no cururu.

A geração que vem vindo não canta igual, parou de passar de pai pra filho.

Hoje tem muito canturino. Você sabe o que é canturiões e canturino? Então, canturiões são os cantadores mais experientes, que cantam há um determinado tempo e que sabem cantar "no livro", fazendo versos bíblicos e que respeitam as regras. Já os canturino são os cantadores que começaram cantar há pouco tempo, que não têm muita experiência, e que geralmente cantam por pouco tempo.

O que canta mais hoje é o repente, mas como falei, num é um repente sadio, hoje é muita bestera.

Já gravei CD, já gravei um em homenage aos artista piracicabano e CD e DVD da apresentação no Rio de Janeiro e um DVD chamado Revelando São Paulo, muito bom.

O que falta pro cururu é o povo saber sobre o verdadero cururu, é fazer um grupo pra fazer oficina de ensinamento pra explicá o verdadero cururu, de raiz, é isso que falta. Eu já tentei achar um espaço, um lugar, aliás, até achei uma casa, o proprietário doava ela, só precisava entrar com a parte de divulgação e o resto de dispesa, mas a prefeitura engavetô meu pedido, ninguém quis sabê.

Se o povo soubesse a verdadeira história do cururu, se soubesse as rima, como faz e por quê, o povo ia dar mais valor. 
Não, hoje não é divulgado. Antes era bem divulgado em lugares de eventos cobrando entrada, culturalmente, hoje canta em bar sem divulgação, de qualquer jeito. Ninguém tá ligando pra divulgação.

Óia, as rádio tinha que fazer um programa com apresentador que conhece o cururu, que explica as coisas certinha, o programa tem que ser na AM e com um cururueiro apresentando, aí sim vai pra frente.

O rapaiz deve de ter uns 36 ano, é o Marcelinho Toledo.

\section{SERGIO FAZANARO}

Meu nome completo é muito comprido, é Sergio Fazanaro... você viu que comprido, extenso.

Eu tenho 65 anos graças a Deus.

Eu comecei a cantar por incrinação, de olho nos amigo, na amizade, aí fui cantando.

Faz só 2 ano que canto, to engatinhando ainda no cururu.

Eu só participei até hoje em bares, não participei de eventos grandes e nem em praça.

A única rádio que participei de programa foi a Rádio Brasil de Santa Bárbara do Oeste, acho que foi só essa mesmo.

Eu acho que o cururu é bem conhecido, mas assim, pelo povo mai véio né, a garotada num se interessa muito não, ocê pode ver aqui, só dá véio, cê num vê uma pessoa mais nova a num ser vocês, (risos) e o outro rapaizinho ali.

A quantidade é a mesma, só que é por causa do povo, eles qué aparecê, tem muita gente querendo aparecê.

O repente é o que toca mais. Pelo menos é o que eu acho.

Não, nunca gravei nada, nem fita.

O que falta para o cururu é divulgação. É falta apoio, divulgação mesmo.

Não é bem divulgado em Piracicaba nunca, ta longe de ser, falta espaço pra nóis divulgá. Precisava de mais ação por parte dos político, dos donos de empresa e de rádio.

Ter mais programa, é isso que tem que ter na rádio, mais programa de cururu. 
O cantador mais novo que conheço é o Mauro, o Bortoleto, mas a idade dele num sei não, é mais que 48, acho.

\section{CHICO MINEIRO}

Meu nome mesmo é Francisco Alexandre, mas sou mais conhecido por Chico Mineiro.

Tô com 65 ano.

Meu tio era cantadô antigo, desde pequeno acompanhava ele, aí fui treinando, treinando e comecei a cantá. Hoje tamo firme aqui cantando.

Que eu comecei a cantá faz uns 25 anos.

Participá eu participo em praças, lanchonetes, festas religiosas, pouso do divino, onde chamam eu vou.

De rádio não participei em nenhuma ainda.

Em Piracicaba o cururu é mais conhecido, na região não, mas mesmo assim falta incentivo.

Hoje pode ter mais cantadô, mas com menos ação, antigamente tinha mais valor. Acho que era mais fácil também, tinha incentivo, tinha inspiração.

O que toca mais é o repente. O desafio é mais na brincadeira, o que toca mais é o repente mesmo.

Não, ainda não gravei nenhum CD.

O que falta na realidade é dar mais apoio, porque a gente paga do bolso pra cantá.

Divulgação? Que divulgação? É divulgado entre a gente, não tem divulgação aberta, é bem pouco falado, ninguém qué sabê, a rapaziada não sabe de nada.

O que falta é fazer programas, podiam fazer eventos, shows com cururueiros. É muito pouco tempo na rádio, só meia hora, tinha que ser mais.

O mais novo é o Bortoleto, deve ter uns 50 anos, é difícil ter adolescente que se interesse, é mais os velho, e mulher é mais difícil ainda.

\section{JOSÉ CARLOS FORTINOVE}

Eu me chamo José Carlos Fortinove, tenho 62 anos 
Comecei a cantar por influência do meu primo, o Zico Claudino, ele canta e eu fui no embalo, fui aprendendo com ele e com outros cururueiro também.

Eu canto a mais ou menos uns 12 anos.

Geralmente participo de eventos como aniversário da cidade, eventos culturais, mas o que faço mais é isso aqui, pelo menos uma vez por mês tento vir cantar aqui no bar, e amanhã vou lá na praça Takaki, lá vai ter cururu também.

Já participei da Difusora, da Alvorada, Municipal.

Só não lembro data e nem nome de programas, tem problema? Num lembro mesmo.

Em Piracicaba falta muito pra ser reconhecido, antes aqui só se falava em cururu, era a capital do cururu que chamavam a cidade, e hoje não tem a mesma tradição. Na região ninguém conhece, muito pouca gente conhece. Falta divulgação.

A quantidade é maior, em qualidade é menor. Os antigos tinham mais devoção, não sei se por causa das enchentes que causavam as doença eles cantavam mais, louvavam mais o santo, hoje não tem mais isso, antes com a festa do divino era mais religioso.

O que toca mais é repente, pode reparar.

Não gravei CD, só gravamos um DVD caseiro pros amigos.

Falta incentivo, porque o dinheiro da cultura é grande e poderia fazer mais pro cururu, hoje o pessoal só qué coisa da moda, num investe em coisa da terra mesmo.

Acho que só é bem divulgo entre a gente que canta, e é só no boca-a-boca, num tem cartaz, ninguém fala na rádio, nem no jornal.

Fazer mais programa de repente, e os espaço na rádio são caros, olha só, esses dias nós fomo ver na Difusora e um programa de uma hora por semana fica em $\mathrm{R} \$ 1.500,00$ por programa, assim é duro achar patrocinador.

Acho que o mais novo que conheço é o Marcelinho, que deve ter uns 38 anos, acho.

\section{MOACIR SIQUEIRA}

Meu nome legível é Moacir Bento de Lima, porque eu fui criado sem pai e sem mãe, seria legítimo Siqueira, que é meu avô, pai do meu pai, que é Sebastião Siqueira, como fui registrado sem pai e sem mãe eu fiquei com o nome do pai que é Moacir Bento de Lima, mas conhecido como Moacir Siqueira.

E a minha idade, eu nasci em 31 de agosto de 1937, eu já completei 69 ano de idade, vou indo pra 70, com a graça de Deus. 
Eu comecei a cantá por dom de família, porque meu to Tico Siqueira, foi um violero, o único violero que foi o primeiro a tocá viola com afinação quatro ponto. Ele é irmão do meu pai, e foi ele quem ensinô a família, os meus primo, os Irmão Siqueira com viola e violão e foi ele também que ensinô vários tocadô também, deu aula pra quase todos os violero de Piracicaba, e tinha também minha prima-irmã, chamada Darci Siqueira, que hoje tá com 80 ano de idade, e ela não canta mais cururu, mais foi a melhor cantadera de cururu e repentista que teve aqui em Piracicaba e região, cantava com Parafuso, Nhô Serra com Pedro Chiquito, com os cantadô mais famoso da história de Piracicaba. E meu pai também cantava, e eu por essa incrinação segui, mas eu não tinha muita vontade de segui, aí no batizado na minha casa do fio do parafuso, foi que eu fiz segunda do parafuso, aí ele me convidava e me incentivô a continuá e foi aí que comecei cantá de 68 pra cá.

Canto faz mais ou menos uns 42 ano.

Participo bastante evento, não me exibindo, fazendo graça, mas já fiz na televisão. No programa da Inesita Barroso, em Capivari, na TVS e região, e no passado, com Rolando Boldrim e Lima Duarte, naquele pograma que tinha antigamente, eu num lembro o nome, na Rede Globo de Televisão, como que era o nome meu Deus do céu, eu sei que foi na Rede Globo. E eu recebi agora pouco em Iracemápolis um diproma de meió repentista do ano [...] e já toquei por esse brasilzão afora.

Aqui em Piracicaba eu já cantei no programa lá do SESI do Moacir Bombo, meu querido Moacir, mai depois uma pessoa lá começou a ir comanda e eu num vortei mai, por motivo que eu num quero fala.

O cururu é conhecido, mais infelizmente o rap, o axé, o pagode, o forró, dominô a povoação que hoje uma criança com dói, treis ano, toco sambão tá pulando pra mai de quilômetro. E até a vaquinha pocotó também induziu muito a criançada.

Eu calculo que é a mema, só que não tem cantadô como tinha antigamente, não quero tirá mérito de ninguém. Antigamente tinha 30, 40 cantadô de cururu, mai tudo de renome, o cururu não parava de jeito nenhum. Agora tem bastante cantadô, mas pra ser sincero, cantadô que toca em lanchonete, em aniversario, mas num é cantadô que tem sucesso pra sê chamado pra cantá. Cantadô bão deve tê uma meia dúzia.

O repente ocê tem que oiá pra pessoa, improvisá e faze na hora, como eu gosto de fazê, e o cururu antigo cê canta saudando, canta louvando em festa de santo, Santo Antonio, São Pedro, São João é mais autentico, cantá sério, com seriedade. Existe o desafio também que é o desafio cana-verde, um canta um verso e outro canta outro, desafio é isso, um verso cada um.

O desafio agrada mais o povo e já o repente demora mais, se ocê me dá uma lista com trinta nome, eu sô capaz de cantá um verso cada nome, eu olho na pessoa e faço na hora. Falo se é gordo, se é magro, se é bonito, da profissão.

Tanto brinco como faço saudação, canto o evangelho também, o velho testamento tá tudo na cabeça, da bíbria, e do novo testamento. O cururu precisa de leitura tamém. 
Eu tenho cinco CD gravado e agora eu tenho DVD também que foi gravado em 2002.

Cantadô novo é difícil, tem o Bybe e Lequinho, que devem ter uns 35 ano. Mas num tem mais não. Tem de $35,40,45,50$, mai minino memo num tem.

A rádio é o seguinte, hoje em dia num tem mais auditório, antigamente na Difusora, no programa do Nhô Serra tinha auditório, o povo vinha, tinha lá umas 150 pessoa e o povo apraudia, era vivo.

Num tá tendo espaço, o espaço seria bão pra valoriza o cururu, pro cururu crescê e pegá fama e chegá no auge onde tá Zezé di Camargo e Luciano, Daniel, o que precisa é mídia, ter recurso financeiro pra gravá e levá na mídia, aí até a juventude vai gosta demai, com certeza cresce. O que precisa é que a programação, os governamentais, os pessoal da cultura, que esses político deveria mostrar essas raiz.

Depois que eu cantei na Inesita Barroso, minha fama cresceu mais. Comecei a cantar mais.

"Eu fui cantá na festa de Tupi, pra umas vinte e cinco mil pessoas, as dez e meia o locutor anunciô eu. Eu cantei, veja bem, lembro como se fosse agora:

Hoje, juventude que me ouve

O Brasil de hoje tá entregue na sua mão

Primeiro, segundo, terceiro e quarto ano o diproma vem na mão

O rio tem que te água de sobra,

todas água dão vorta seu diproma não.

Quinta, sexta, sétima e oitava série segue outra direção

Com muita dificuldade eu construí toda cidade

Formá na faculdade uma boa profissão.

Cadê os aprausos desse povo? Ninguém apraudiu, mas continuei:

Vamo todo mundo apraudí, em nome do rei Davi

Hoje aqui em Tupi um viva a São João.

Era o padroeiro, festa de São João... pouco aprauso. Veja bem, a TV nem interessô. Aí eu mudei, foi a hora que eu parti pro funk, eu falei:

Vem de cá minha popozuda, quero ver seu popozão

Martela, martela, martela o martelão

Fica entre nói, tapinha não dói

Não vô metê minha mão

E na dança da motinha popozuda perde a linha

Eu vô pegá ocê na estação.

Aí arrebentô a boca do balão, chegô junto todo mundo comigo, até político subiu no palco, deputado estadual, federal, prefeito, subiram no palco pra ficá comigo. Aí aproveitei:

A preparada no salão

Dando rebolada de cima até no chão 
Qué dança, qué dança o tigrão vai te ensiná

Eu passei cerol na mão

Beijo doce como açúcar,

Vem minha pitchuca

Aqui tá o teu tigrão.

A preparada no salão

Na motinha do tigrão

Rebolando o corpinho de violão

Eu num quero que ninguém morra

E as cachorra?

Óia aqui mai um cachorrão

Quero vê se eu consigo

Sê um cachorro amigo

Do que um amigo cão

Tem muita mulher mudando de opinião

Fazendo cirurgia com bom cirurgião

Eu não sô ingnorante

Tão fazendo imprante a famosa imprantação

Eu falo pelo microfone

De tanto silicone

A laranjinha virô mamão

Vô falá pro cê, pelo amor de Deus, todo mundo apraudiu.

Tem mai coisa tembém.

Esse hómi é pouca teia

A careca dele parece que clareia

No sol quente, no inverno e no verão

Só que por ser careca,

Não é o cabelo que faz o hómi

O importante é a educação

Mas o sabiá escapou da arapuca

Nói vai compra uma piruca

Pra sarvá sua situação

Agora tenho que í que o pessoal ta esperando lá pra ir cantá.

Depois a gente se fala. 


\section{APÊNDICE 4 - Entrevista com representantes de rádios}

\section{GILBERTO FREITAS}

Meu nome é Gilberto Freitas, minha idade eu não revelo, é segredo de Estado.

Já trabalhei na FM Municipal e também na antiga Rádio Alvorada AM

Na Municipal, que hoje é Educativa ainda existe, tem todos os domingos de manhã, e quem apresenta é o Moacir Siqueira, mas na Alvorada acabou acho que em 2005, mas não era eu quem apresentava. Hoje eu apresento os cururueiros nas praças, quando precisa.

Eu comecei na FM Municipal há 14 anos atrás, o programa ia ao ar no domingo também, mas não era tão cedo como hoje, era um pouco mais tarde, começava umas oito e meia da manhã e ia até umas dez e meia. Na Alvorada eu entrava de vez em quando em horários diferentes, se tivesse patrocinador entrava no ar, senão não entrava.

Hoje não existe mais nenhum, você vê?

$\mathrm{Na}$ época que eu fiz os programa o cururu era a sensação, era disputado, então resolveram na rádio fazer algo do estilo, e precisava ser um locutor que conhecia os cururueiros, na época eu conhecia, como até hoje eu conheço, aí me chamaram pra fazer o programa.

A audiência era calculada através de telefonemas dos ouvintes, às vezes a gente abria pra pessoa falar no ar e então a gente tinha uma base de quantas pessoas ligavam, eu não me lembro bem a quantidade, mas era bem ouvido, era mais pessoas com uns 40, 45 anos que ligavam.

$\mathrm{Na}$ época as duas realizavam eventos, eram shows, palcos nas praças e nas próprias rádios, aí com o tempo foi terminando este tipo de atividade, as rádios não deram uma continuidade. Pra se ter uma idéia, a Alvorada virou Globo e nem programa de cururu tem, e a Educativa tem, mas é bem de manhã e muito pouco tempo. O espaço nas rádios está acabando.

Eu faço eventos de Rodeio, cururu e sertanejo.

Na FM Municipal era ao vivo com os cururueiros, isso que era interessante e diferente, hoje a educadora faz ao vivo também, e é a única.

Olha o cururu caipiracicabano é a tradição de Piracicaba e do estado de São Paulo, hoje a velha guarda pouco existe, mas as revelações nos surpreende a cada dia que passa e o cururu caipiracicabano jamais vai deixar de existir se houver espaço nas rádios e na cidade.

O que falta é abrir mais espaço de horário aos cururueiros, falta apoio pra que Piracicaba não deixe de existir o nosso folclore. 


\section{ADAIR DONIANI (SAMARITANO)}

Bom, o nome é Adair Doniani, mas o pessoal me conhece mais por Samaritano, porque eu tenho uma dupla sertaneja e me chamam de Samaritano, aí fiquei conhecido assim. Eu tenho hoje 55 anos.

A rádio que eu trabalho a gente chama de Educadora Jovem pan, porque as vezes tem programação da Jovem Pan.

A rádio é AM 1060 quilohertz.

Hoje existe um programa que é transmitido direto do SESI, na avenida Rhalphi Penati número 600 , ele é um programa ao vivo que tem a primeira hora de cururu e depois vem moda raiz, moda-de-viola.

Este programa especificamente vem desde o dia 10 de maio de 1983, começou no SESC, sabe?, lá na rua Ipiranga, e a 9 anos realizamos no SESI aos domingos das 10 ao meio-dia.

Os locutores do programa são José Moacir Bombo e eu, Samaritano. O operador de áudio é o Roberto Regonha, e o restante da equipe externa da rádio é o José Carlos Medeiros, o Camarão, o Paulinho, o Joaquim Antonio e o Mendes Neto.

Nós preocupamos em manter a tradição do nosso cururu e a música sertaneja e moda raiz conhecida como moda-de-viola na programação, a gente procura ajudar as culturas piracicabanas

O nível de audiência é satisfatório, não há um cálculo específico, a gente tem uma base através do boca-a-boca, da amizade. A gente também calcula pelas pessoas que comparecem no programa, que devem ter entre uns 40 a 80 anos.

A rádio realiza eventos na época de seu aniversário.

O nosso Som da Terra é ao vivo, como programa de auditório, as pessoas vêm assistir no local, em outras rádios é rolado CDs, MDs, não tem contato com o público. Esse é o nosso diferencial do programa.

\section{ANTONIO CELSO RIBEIRO}

O nome é Antonio Celso Ribeiro da Silva, tenho 59 anos e sou o funcionário mais velho da Difusora, trabalho aqui desde abril de 69. É tempo, hein?, mas eu gosto disso aqui, eu respiro rádio.

Eu sou técnico de áudio, faço programação, ajudo na formação dos programas, faço de tudo um pouco aqui dentro.

O nome da rádio mesmo é Rádio Difusora de Piracicaba S.A. olha eu tô falando tanto pra AM quanto pra FM tá? É que como eu sou o mais antigo aqui, eu sei mais 
sobre a história da rádio; o resto do pessoal muda muito, entra locutor novo, sai locutor, então eu que vou falar pelas duas.

A AM - ZYK 524 com freqüência de 650 quiilohertz e a FM é 102,3

Hoje não existe não, parou já faz um tempo, eu num lembro horário, mas sempre existiu, desde o começo da rádio, me lembro dos programas de cururu nas épocas de 60 a 80, que eram apresentados por grandes cantadores como o Nhô Serra, o Parafuso, mas esses programas acabaram no começo dos anos 80 por questões comerciais.

Essas questões comerciais que eu não sei falá pra você. O que a diretoria disse foi isso, questões comerciais. Alguns dizem que é por causa de registrar o cururueiros, mas isso eu não posso afirmar.

Os locutores eram os apresentadores e cantores, alguns que eu lembro é Nhô Serra, Pedro Chiquito, Parafuso, Moacir Siqueira e outros que não lembro agora.

Pra colocar os programas no ar não foi tão difícil; na época eles (cantadores de cururu) faziam shows em praças públicas e os então diretores resolveram convidálos a fazer o tal programa de cururu, que na época foi sucesso, era bem conhecido.

A audiência era calculada pela freqüência e telefonemas do público, mas não sei dizer quantos telefones por programa e nem a idade. Eu não participava nesta área na época.

Hoje rádio não realiza mais nada com cururu. Realizava antes, mas agora não.

O formato mudava, no começo fiquei sabendo que era ao vivo, às vezes até transmitido de alguns lugares onde tinha os shows, mas depois foi feito do estúdio da rádio mesmo, ao vivo também, mas do estúdio.

\section{MOACIR SIQUEIRA}

O meu pograma é na Educativa das 6 às 8 da manhã e Piracicaba ouve a programação, eu tenho gravação de antigamente e às vez a gente grava novo e eu levo na discoteca da Educativa e eles faz um trabalho e passa pro computador, depois tira do computador e coloca na programação e eu entro quarta-feira a oito e meia da manhã e gravo pro domingo, e também dupra bem raiz, eu gosto de sertaneja e não de "sertanojo", eu pego essas dupra, pego CD, tiro cópia e levo pro pograma.

Antigamente, autorizava nói grava de segunda-feira à noite, mas o novo prefeito não quis mais pagá hora extra para o técnico de som ficá com nóis pra gravá. Nóis ia graciosamente cantá, mas ele não aceitô pagá.

A Educativa começou a transmitir o programa de cururu desde 89, um ano depois da inauguração; o programa era apresentado pelo Parafuso, e depois dele por outros cururueiros. 
O pograma é cururu e música raiz, são duas hora de pograma, tem cinco bróco de vinte minuto, cada bróco toca duas dupla sertaneja e dois cantador de cururu.

Antes o pograma era ao vivo da Rua do Porto, do Semae ou de outros lugares, no ultimo mandato do PT passou a ser gravado e depois com o novo prefeito, o PSDB, acabaram as gravações, só do locutor e seleção de música como falei é eu que levo CD lá e a gente escolhe.

Nóis tamo tentando achar parceria pra levar o pograma pra algum bairro, pra transmiti ao vivo, que nem pograma de auditório, pro publico assistir e podê participá, mai tá difícil. 
VIII - ANEXOS 


\section{Anexo 1 - PROGRAMAÇÃO DIFUSORA AM}

\section{Programação Semanal}

00:00 às 04:00
A sua madrugada com as melhores músicas.

04:00 às 07:00

Festa Sertaneja.

Muita música sertaneja.

Apresentação: Robison Valério

\section{7:00 às 07:30}

Jornal Primeira Hora

Noticiário completo com os principais assuntos da cidade, do Estado, do País e do mundo.

\section{7:30 às 09:00}

Manhã Total

Músicas variadas, prêmios, notícias, novelas etc.

Apresentação: -

\section{9:00 às 11:00}

Show da Manhã

Músicas variadas, prêmios e notícias.

Apresentação: Gerson Mendes.

\section{1:00 às 11:30}

Jornal da Difusora 1a Edição.

Política, cotidiano, cultura e esporte. A informação e a prestação de serviços.

\section{1:30 às 12:00}

Show de Bola 1. a Edição

\section{2:00 às 12:30}

Esporte Notícia

Apresentado por Sérgio Patrick, o programa informa os principais fatos do Esporte com a participação de convidados ao vivo e de toda a equipe da Bandeirantes.

\section{2:30 às 15:00}

Viola de Ouro

Muita música sertaneja, prêmios, humor, etc.

Apresentação: Robison Valério.

\section{5:00 às 16:00}

Linha Direta

Entrevistas e Debates.

Apresentação: Edirley Rodrigues.

\section{6:00 às 17:30}

De bem com a Vida

Músicas em alto astral e com muita animação para o final de tarde.

Apresentação: Fernandinho.

\section{7:30 às 17:55}

Jornal da Difusora 2.a Edição

Política, cotidiano, cultura e esporte. A informação e a prestação de serviços.

\section{7:55 às 18:00}

Mensagem de Reflexão / Ave-Maria 
18:00 às 18: 30

Jornal Três Tempos

Entrevistas ao vivo sobre temas em destaque no dia.

Palavra dos colaboradores sobre saúde, educação, qualidade total, publicidade, vinhos, gastronomia e tecnologia da informação.

Apresentação: Fernandinho.

18:30 às 19:00

Show de Bola 2.a Edição

19:00 às 20:00

Espaço do Ouvinte

Serviço de utilidade pública. Espaço com a participação ao vivo do ouvinte vendendo, trocando, etc.

Apresentação: Fernandinho.

20:00 às 23:00

Expresso Noturno

Muita música sertaneja e muitos prêmios.

23:00 às 00:00

A Voz do Brasil

Central de J ornalismo Difusora: Notícia de Hora em Hora

09:00 - 10:00 - 14:00 - 15:00 - 16:00 - 17:00 - 20:00 - 21:00 - 22:00

\section{Programação de Sábado}

\section{0:00 às 05:00}

A sua madrugada com as melhores músicas.

\section{5:00 às 07:00}

Festa Sertaneja

A sua manhã de sábado começa muito melhor com muita música sertaneja.

Apresentação: Robson Valério.

07:00 às 07:30

J ornal Prime ira Hora

Noticiário completo com os principais assuntos da cidade, do Estado, do País e do mundo. 
07:30 às 08:00

Aconteceu

Retrospectiva com os fatos da semana.

08:00 às 11:00

Sábado na Difusora

Musical variado e distribuição de prêmios.

Apresentação: -

11:00 às 12:00

Sábado Debate

Entrevistas e debates.

Apresentação: Edirley Rodrigues.

12:00 às 16:00

Show Sertanejo

Músicas sertanejas.

Apresentação: Tarcílio Dossi.

16:00 às 18:30

Sábado na Difusora

Musical variado e distribuição de prêmios.

Apresentação: -

08:00 às 11:00

Rota do Sucesso

A sua tarde de sábado com muita música sertaneja e muita descontração.

Apresentação: Pitú J r.

18:30 às 19:30

Programa Abri as Portas ao Redentor

(Igreja Católica)

19:30 às 20:30

Transmissão da Missa Católica.

20:30 às 00:00

Muita descontração com as melhores músicas.

Central de J ornalismo Difusora: Notícia de Hora em Hora

09:00 - 10:00 - 14:00 - 15:00 - 16:00 - 17:00 - 20:00 - 21:00 - 22:00

\section{Programação de Domingo}

\section{0:00 às 05:00}

A sua madrugada com as melhores músicas.

\section{5:00 às 09:00}

Festa Sertaneja

A sua manhã de domingo começa muito melhor, com muita música sertaneja.

Apresentação: Robson Valério.

\section{9hs às 14:00}

Domingo Alto Astral

Um programa para alegrar ainda mais o seu domingo.

Apresentação: Dinho Morelli.

\section{4:00 às 21:30}

Plantão Esportivo

21:30 às 24:00

Muita descontração com as melhores músicas. 
Anexo 2 - PROGRAMAÇÃO DIFUSORA FM

\section{Programação de Segunda à Quinta}

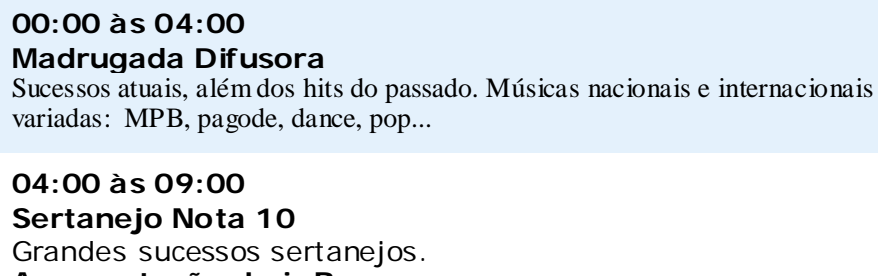

\section{2:00 às 13:00}

Flashback Difusora

Programação com as melhores músicas das décadas de 70,80 e 90 . Apresentação: Anderson Colla.

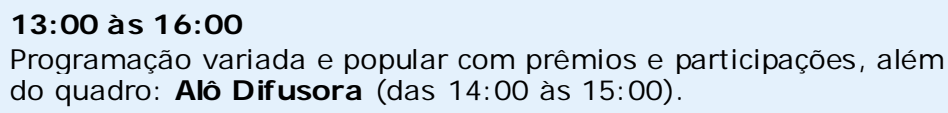

As Melhores da Difusora

As músicas mais pedidas por nossos ouvintes durante a programação.



\section{Programação de Sexta}

00:00 às 04:00

Madrugada Difusora

Sucessos atuais, além dos hits do passado. Músicas nacionais e internacionais

variadas: MPB, pagode, dance, pop... 
04:00 às 09:00

Sertanejo Nota 10

Grandes sucessos sertanejos.

Apresentação: Lair Braga.

09:00 às 12:00

Manhã Alto Astral

Programa musical com a participação de ouvintes, dicas,

informações, prêmios e muito mais.

Apresentação: Anderson Colla.

\section{2:00 às 13:00}

Flashback Difusora

Programação com as melhores músicas das décadas de 70,80 e 90 . Apresentação: Anderson Colla.

\section{3:00 às 16:00}

Programação variada e popular com prêmios e participações, além do quadro: Alô Difusora (das 14:00 às 15:00).

\section{6:00 às 17:00}

As Melhores da Difusora

As músicas mais pedidas por nossos ouvintes durante a programação.

\section{7:00 às 20:00}

Sertanejo Bom Demais

Descontração e o melhor da música sertaneja.

Apresentação: Duarte Yamanaka

\section{0:00 às 21:00}

As Melhores da Difusora

As músicas mais pedidas por nossos ouvintes durante a programação.

\section{1:00 às 00:00}

Grandes sucessos nacionais e internacionais para agitar a noite do fim de semana.

\section{Programação de Sábado}

\section{0:00 às 04:00}

Madrugada Difusora

Sucessos atuais, além dos hits do passado. Músicas nacionais e internacionais variadas: MPB, pagode, dance, pop...

\section{4:00 às 09:00}

Sertanejo Nota 10

A sua manhã de sábado começa bem com o melhor da música sertaneja.

Apresentação: Lair Braga.

\section{9:00 às 12:00}

Manhã Alto Astral

Programa musical com a participação de ouvintes, dicas, informações, prêmios e muito mais.

Apresentação: Anderson Colla. 


\section{Programação de Domingo}

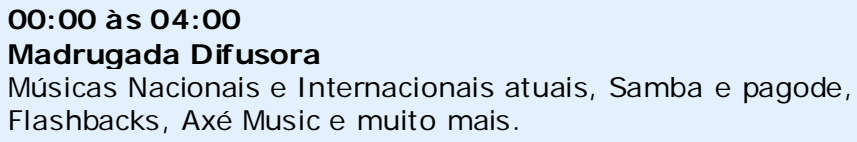

\section{1:00 às 14:00}

Difusa mba

Descontração, prêmios, muito samba, pagode, axé.

\section{4:00 às 17:00}

Tarde repleta de músicas, nacionais e internacionais.

17:00 às 22:00

Entrando no pique da noite de Domingo com muita música.

\section{2:00 às 00:00}

Difusora By Night

O Programação romântica, com as melhores músicas de todos os tempos e a participação de ouvinte por telefone. .

Apresentação: Raphael. 


\section{Anexo 3 - PROGRAMAÇÃO EDUCATIVA}

\section{- Programação}

Segunda-feira

00:00 / 06:00

Flash Back

06:00 / 07:00

Café Com Viola

07:00 / 09:00

Bom Dia Cidade

09:00 / 11:00

Programação Musical (Nacional)

$11: 00 / 12: 00$

Bem Mulher

$12: 00 / 13: 00$

A La Carte

13:00 / 16:00

Programação Musical (Nacional e Internacional)

16:00 / 18:00

Programação Musical (Flash Back Internacional)

18:00 / 18:30

Chamada Geral

18:30 / 19:00

Happy Hour

19:00 / 20:00

Voz Do Brasil

20:00 / 23:00

Sessão da Câmara de Vereadores de Piracicaba

23:00 / 00:00

Programação Musical (Internacional)

Terça-feira

00:00 / 06:00

Flash Back

06:00 / 07:00

Café Com Viola

07:00 / 09:00

Bom Dia Cidade

09:00 / 12:00

Programação Musical (Nacional)

12:00 / 13:00

A La Carte

13:00 / 16:00

Programação Musical (Nacional e Internacional) 
16:00 / 18:00

Programação Musical (Flash Back Internacional)

18:00 / 18:30

Chamada Geral

18:30 / 19:00

Happy Hour

19:00 / 20:00

Voz Do Brasil

20:00 / 00:00

Programação Musical (Internacional)

Quarta-feira

00:00 / 06:00

Flash Back

06:00 / 07:00

Café Com Viola

07:00 / 09:00

Bom Dia Cidade

09:00 / 12:00

Programação Musical (Nacional)

12:00 / 13:00

A La Carte

13:00 / 16:00

Programação Musical (Nacional e Internacional)

16:00 / 18:00

Programação Musical (Flash Back Internacional)

18:00 / 18:30

Chamada Geral

18:30 / 19:00

Happy Hour

19:00 / 20:00

Voz Do Brasil

20:00 / 00:00

Programação Musical (Internacional)

Quinta-feira

00:00 / 06:00

Flash Back

06:00 / 07:00

Café Com Viola

07:00 / 09:00

Bom Dia Cidade

09:00 / 12:00

Programação Musical (Nacional)

12:00 / 13:00

A La Carte 
13:00 / 16:00

Programação Musical (Nacional e Internacional)

16:00 / 18:00

Programação Musical (Flash Back Internacional)

18:00 / 18:30

Chamada Geral

18:30 / 19:00

Happy Hour

19:00 / 20:00

Voz Do Brasil

20:00 / 23:00

Sessão da Câmara de Vereadores de Piracicaba

23:00 / 00:00

Programação Musical (Internacional)

Sexta-feira

00:00 / 06:00

Flash Back

06:00 / 07:00

Café Com Viola

07:00 / 09:00

Bom Dia Cidade

09:00 / 12:00

Programação Musical (Nacional)

12:00 / 13:00

A La Carte

13:00 / 16:00

Programação Musical (Nacional e Internacional)

16:00 / 18:00

Programação Musical (Flash Back Internacional)

18:00 / 18:30

Chamada Geral

18:30 / 19:00

Happy Hour

19:00 / 20:00

Voz Do Brasil

20:00 / 00:00

Flash Night (Internacional)

\section{Sábado}

00:00 / 06:00

Flash Back

06:00 / 08:00

Café Com Viola

08:00 / 10:00

Pira 21 
10:00 / 11:00

Educativa nas Letras

11:00 / 13:00

Pérolas Do Samba

$13: 10 / 15 h 00$

Resgate 105

15:00 / 17:00

Programação Musical (Nacional e Internacional)

17:00 / 18:00

Oxigênio

18:00 / 19:00

Cartaz de Cinema

19:00 / 22:00

Programação Musical (Internacional)

22:00 / 00:00

Camja (Jazz)

Domingo

00:00 / 06:00

Flash Back

06:00 / 08:00

Nossa Terra, Nossa Gente

08:00 / 11:00

Pelos Caminhos da Saudade (Seresta, Bossa-Nova e Jovem Guarda)

11:00 / 13:00

Pérolas Do Samba

13:00 / 17:00

Programação Musical (Nacional e Internacional)

17:00 / 18:00

Pop Mania

18:00 / 20:00

Reprise - Camja

20:00 / 21:00

Opus 105,9

21:00 / 00:00

Programação Musical (Internacional) 
Anexo 4 - PROGRAMAÇÃO EDUCADORA AM

\begin{tabular}{|c|c|c|c|}
\hline \multicolumn{4}{|c|}{ Segunda à Sexta } \\
\hline HORÁRIO & PROGRAMA & APRESENTADOR & ESTI LO \\
\hline 00: 00 às $04: 55$ & Transmissor desligado & Um bom dia prá você !!! & $\begin{array}{l}\text { Voltaremos AO AR às } \\
5: 00 \text { hs }\end{array}$ \\
\hline 05: 00 às 07:00 & Manhãs Brasileiras & Luis Carreteiro & Sertanejo Raiz \\
\hline 07: 00 às 08: 00 & $\begin{array}{l}\text { Programa Djansen de } \\
\text { Lima }\end{array}$ & Djansen de Lima & Variedades \\
\hline 08: 00 às 09: 00 & Alô Bom Dia & Mário Luis & Jornalismo Serviço \\
\hline 09: 00 às 12:00 & Programa Da Amizade & Titio Luiz & Variedades Família \\
\hline $12: 00$ às $13: 30$ & $\begin{array}{l}\text { COMENTARISTAS DA } \\
\text { EDUCADORA }\end{array}$ & $\frac{\text { Márcio Terra, Eliana Teixeira, }}{\underline{\text { Valdir Guimarães }}}$ & $\begin{array}{l}\text { Comentário, } \\
\text { orientação. }\end{array}$ \\
\hline $13: 30$ às $15: 30$ & Boa Tarde Com Alegria & Celso Melotto & Variedades \\
\hline $15: 30$ às $16: 30$ & Emoções & Walter Silva & $\begin{array}{l}\text { Roberto Carlos } \\
\text { Exclusivamente }\end{array}$ \\
\hline $16: 30$ às 18: 30 & Chapéu de Palha & Dario Corrêa & Sertanejo Popular \\
\hline 18: 30 às 19:00 & Hora da Verdade JP SAT & $\underline{\text { Rede Jovem Pan SAT }}$ & J ornalismo Serviço \\
\hline 19:00 às 20:00 & AGENCI A NACI ONAL & $\underline{\text { Rede J ovem Pan SAT }}$ & \\
\hline $20: 00$ às $21: 00$ & Esporte da Educadora & Mário Luis & $\begin{array}{c}\text { Esportes / J ogos AO } \\
\text { VIVO }\end{array}$ \\
\hline $21: 00$ às $22: 30$ & Educadora à dois & Jeane Tenório & Romântico AO VIVO \\
\hline $22: 30$ às $23: 00$ & Rádio Caminhoneiro & Sérgio Reis & Sertanejo I nformativo \\
\hline $23: 00$ às $24: 00$ & Musical ou Futebol & Discoteca e JP SAT AM & Musical / Futebol \\
\hline
\end{tabular}

\begin{tabular}{|c|c|c|c|}
\hline \multicolumn{4}{|c|}{ Sábado } \\
\hline HORÁRIO & PROGRAMA & APRESENTADOR & ESTILO \\
\hline 00: 00 às 06: 00 & Retornaremos às 6 horas. & & $\begin{array}{l}\text { Voltaremos logo mais com J osé } \\
\text { Moacir. }\end{array}$ \\
\hline 06: 00 às 08: 00 & A Voz do Sertão & Losé Moacir & Sertanejo Raiz \\
\hline 08:00 às 10:00 & TV a Lenha & $\underline{\text { Schimidt }}$ & Memória da TV e do RÁDIO \\
\hline 10: 00 às $11: 00$ & $\begin{array}{c}\text { Piracicaba Histórias e } \\
\text { Memórias }\end{array}$ & Loão Nassif & Entrevistas \\
\hline $11: 00$ às $12: 00$ & Novo Dia & Cida Abe & Variedades \\
\hline $12: 00$ às $13: 00$ & Bola na Várzea & Dinival Tibério & Futebol Varzeano \\
\hline 13: 00 às 15: 00 & Música e Informação & $\frac{\text { Discoteca e JP SAT }}{\underline{A M}}$ & I nformação, música e serviços. \\
\hline 15: 00 às 16: 00 & Beto Lobão & Beto Lobão & Sertanejo raiz. \\
\hline 16:00 às 18: 00 & Futebol AO VIVO & $\underline{\text { Rede Jovem Pan SAT }}$ & Futebol, a emoção do Brasileiro !! \\
\hline 18:00 às 19:00 & Santa Missa (Vila Rezende) & Linha Especial & Missa Católica \\
\hline $19: 00$ às $22: 00$ & Religioso & Linha Especial & Religioso Musical \\
\hline
\end{tabular}




\begin{tabular}{|c|c|c|c|}
\hline \multicolumn{1}{|c|}{ HORÁRI O } & PROGRAMA & APRESENTADOR & ESTILO \\
\hline \hline 05:00 às 10:00 & Prog. Zé Mineiro & Zé Mineiro e equipe & Sertanejo Raiz \\
\hline 10:00 às 12:00 & Som da Terra & José Moacir & Sertanejo AO VIVO direto do SESI \\
\hline 12:00 às 14:30 & Craveiro e Cravinho & Craveiro e Cravinho & Sertanejo Raiz \\
\hline 14:30 às 21:00 & Jornada Esportiva & Rede Jovem Pan SAT & Esportes \\
\hline 21:00 às 22:00 & Domingo Instrumental & Celso Melotto & Música Erudita \\
\hline 22:00 às 24:00 & Música e Informação & Rede Jovem Pan SAT & Musical \\
\hline
\end{tabular}

